\title{
Distribution and diversity of Fagaceae in Hidalgo, Mexico
}

\section{c) creative commons}

Botanical Sciences 95 (4): 660-721, 2017

DOI: $10.17129 /$ botsci.1020

Received:

November 14th, 2016

Accepted:

April 20th, 2017

Associate Editor

Juan Núñez Farfán
Copyright: (c) 2017 Valencia-A et al. This is an open access article distributed under the terms of the Creative Commons Attribution License, which permits unrestricted use, distribution, and reproduction in any medium, provided the original author and source are credited.

${ }^{1}$ Universidad Nacional Autónoma de México, Departamento de Biología Comparada, Herbario de la Facultad de Ciencias, Ciudad Universitaria, Circuito exterior s.n. Coyoacán 04510, Ciudad de México, Mexico

${ }^{2}$ Universidad Autónoma del Estado de Morelos. Centro de Investigaciones en Biodiversidad y Conservación (CIByC).

${ }^{3}$ Universidad Nacional Autónoma de México, Departamento de Botánica, Instituto de Biología, Ciudad Universitaria, Coyoacán 04510, Ciudad de México, Mexico

* Corresponding author: svalenciaa.unam@gmail.com

\author{
Susana Valencia-A. ${ }^{1 *}$, Gabriel Flores-Franco², Jaime Jiménez-Ramírez ${ }^{1}$ y \\ MAURICIO MORA-JARVIO 3
}

\section{Abstract}

Background: The family Fagaceae is one of the most important in temperate regions of the Northern hemisphere. Fagus and Quercus are distributed in Mexico, the former in Northeastern Mexico, while the latter reaches a high diversity in the Sierra Madre Oriental, Mexico. In Hidalgo state, located mainly in the Sierra Madre Oriental, knowledge of the Fagaceae diversity is still uncertain.

Questions and/or hypothesis: We carried out a taxonomic revision of the genus and species of Fagaceae in Hidalgo state. We determined how many and which species are distributed in Hidalgo. We also present a morphological description and ecological characters of each one.

Studied species: The species of the family Fagaceae.

Study site: Hidalgo state, Mexico.

Method: We collected herbarium specimens, made field observations and reviewed herbarium data of Fagaceae specimens at FCME, INEGI, MEXU, ENCB, SLPM, HUAP, HUMO, XAL and partly BH herbaria. In addition, we checked taxonomic literature and protologues of each species.

Results: We found one species of Fagus and 43 of Quercus, 22 of which belong to the section Quercus (white oaks) and 21 to section Lobatae (red oaks). Morphological descriptions, altitudinal and geographical distribution, vegetation types of each species and a dichotomous key for species identification are presented. Illustrations and photographs of the species are also included.

Conclusions: A high diversity of Fagaceae species is present in Hidalgo state. In Mexico, Hidalgo ranks in fifth place for oak species diversity, just behind Oaxaca (50 species), Puebla (50), San Luis Potosí (45), and Jalisco (45).

Keywords: Fagus, Quercus, floristics, Hidalgo state, Mexico.

\section{Resumen}

Antecedentes: La familia Fagaceae es una de las más importantes en las regiones templadas del Hemisferio Norte. Fagus y Quercus se distribuyen en México, el primero en el noreste, el último alcanza una gran diversidad en la Sierra Madre Oriental, México. En el estado de Hidalgo, ubicado principalmente en la Sierra Madre Oriental, el conocimiento de la diversidad de la familia Fagaceae es aun incompleto.

Preguntas y/o hipótesis: Realizamos una revisión taxonómica de los géneros y las especies de la familia Fagaceae en el estado de Hidalgo. Determinamos cuántas y cuáles especies se distribuyen en Hidalgo. También presentamos descripciones morfológicas y datos ecológicos de cada especie.

Species estudiadas: Las especies de la familia Fagaceae.

Sitio de estudio: Estado de Hidalgo, México.

Método: Colectamos ejemplares para herbario, hicimos observaciones de campo para las especies y revisamos los ejemplares de Fagaceae depositados en los herbarios FCME, INEGI, MEXU, ENCB, SLPM, HUAP, HUMO, XAL y parcialmente en BH. Adicionalmente revisamos la literatura taxonómica y los protólogos para cada especie.

Resultados: Encontramos una especie de Fagus y 43 de Quercus, 22 de las cuales pertenecen al section Quercus (encinos blancos) y 21 a section Lobatae (encinos rojos). Se presentan descripciones morfológicas, datos de distribución altitudinal, geográfica y por tipos de vegetación para cada especie; así como una clave dicotómica para su identificación. También se incluyen ilustraciones y fotografías de las especies.

Conclusiones: El estado de Hidalgo contiene una alta diversidad de especies de Fagaceae. Esta entidad ocupa el quinto lugar de diversidad de Fagaceae después de Oaxaca (50 especies de encinos), Puebla (50), San Luis Potosí (45) y Jalisco (45).

Palabras clave: Fagus, Quercus, florística, estado de Hidalgo, México. 


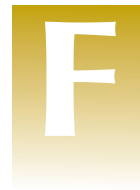

agaceae is one of the most important families of Angiosperms in the temperate regions of the Northern hemisphere. It comprises 10 genera: Lithocarpus, Trigonobalanus, Colombobalanus, Formanodendron, Chrysolepis, Castanea, Castanopsis, Quercus, Fagus (Nixon \& Crepet 1989) and the recently segregated genus Notholithocarpus (Manos et al. 2008). In Mexico Quercus is represented by 161 of the 500 species known worldwide (Manos et al. 1999, Valencia-A. 2004, Aldrich \& Cavender-Bares 2011). Later, Villaseñor (2016) cited 174 names of species of Quercus in Mexico. But for Fagus only F. grandifolia subsp. mexicana (Martínez) E. Murray is present in the country, in small populations in the states of Hidalgo, Nuevo León, Puebla, San Luis Potosí, Tamaulipas and Veracruz (Rodríguez-Ramírez et al. 2013).

The state of Hidalgo is located in the central region of Mexico (INEGI 1992, Figure 1), one of the richest in oak species diversity (Nixon 1993, Valencia-A. 2004; Valencia-A. \& Gual-Díaz 2014), which has motivated the study of the genus Quercus in certain locations of the state and the discovery of several new species. During the 19th Century, many species of this genus were described, including Quercus castanea Née, Q. elliptica Née (Née 1801), Q. laurina Bonpl., Q. depressa Bonpl., Q. repanda Bonpl. (Bonpland 1809), Q. affinis Scheidw. (Scheidweiler 1837) and Q. glabrescens Benth. (Bentham 1840). In the 20th Century, Trelease (1924) described $Q$. alpescens Trel., Q. opaca Trel., Q. toxicodendrifolia Trel. and $Q$. trinitatis Trel., all of them from Hidalgo. Martínez (1940) described Fagus mexicana.

Zavala-Chávez (1995) studied the oaks of the Parque Nacional El Chico, where he documented 20 species of Quercus and later published Q. pachucana Zavala (Zavala-Chávez 2000) as a new species. Valencia-A. \& Cartujano-P. (2002) registered Q. pinnativenulosa C.H. Mull. in the state of Hidalgo and Vázquez et al. (2004), described Q. hirtifolia as a new species based on material collected in the same state. Álvarez-Zúñiga et al. (2010) registered 18 species of oaks in the Parque Nacional Los Marmoles, and Valencia et al. (2011) described Q. delgadoana based on the type specimen collected in Hidalgo. Even though there are several studies on this matter, a comprehensive taxonomic and floristic study of this genus in the state of Hidalgo is still missing. In addition, the continuous forest fragmentation, especially of the woodlands in the main montain regions of Mexico, and the scarce botanical knowledge of the family and genus in eastern Mexico emphasize the importance of studying these taxa in the state of Hidalgo. The aim of this study is to contribute to the taxonomic knowledge of the Fagaceae in the state of Hidalgo. We present a specific floristic list and identification keys for genera and species, with the corresponding descriptions and general distribution of each species within the state.

\section{Author contributions}

Susana Valencia-A. Conceived the original idea, planned the development of the study of Fagaceae in Hidalgo state, collected botanical specimens, wrote the descriptions of species and wrote the manuscript.

Gabriel Flores-Franco planned and conducted the collection of botanical specimens of familiy Fagaceae in Hidalgo. He also provided ecological characters for each species and reviewed herbaria. Jaime Jiménez-Ramírez wrote the descriptions and reviewed the literature.

Mauricio Mora-Jarvio collected botanical specimens of the familiy Fagaceae, and reviewed herbaria.
Study zone. According to INEGI (2014), the state of Hidalgo is located between $19^{\circ} 36^{\prime}$ and $21^{\circ} 24^{\prime}$ North and $97^{\circ} 58^{\prime}$ and $99^{\circ} 53^{\prime}$ 'West. The area of the state is approximately $20,813 \mathrm{~km}^{2}$, representing $1.1 \%$ of the total surface of Mexico. The state is divided into 84 municipalities, and shares its borders with San Luis Potosí (North), Veracruz (Northeast), Puebla (Southeast), Tlaxcala (South), Estado de Mexico (South) and Querétaro (West). The altitude within the state ranges from $180 \mathrm{~m}$ in the canyon of the Sierra Madre Oriental, in the province of Carso Huasteco, and up to 3,350 $\mathrm{m}$ in the Cerro La Peñuela, located in the southwestern region of the state.

There are three physiographic provinces in the state: a) The Sierra Madre Oriental in the northern region of the state, covering approximately $62 \%$ of the total surface; b) the TransMexican Volcanic Belt at the south, with $37.4 \%$ of the total surface, and c) the Mexican Gulf Coastal Plain at the northeastern region, with a $0.27 \%$ of the total surface.

Due to its location and physiography, three main climates are recognized: tropical and subtropical climates are present in the lower portions of the Sierra Madre Oriental facing the Gulf of Mexico; temperate and semi-temperate climates occur in the highlands of the Sierra Madre Oriental and Trans-Mexican Volcanic Belt; arid and semi arid climate characterize the Metztitlan Canyon and the Central Meseta of Hidalgo (Martínez-Morales et al. 2007).

Besides of the aquatic vegetation flourishing in the lakes, rivers and lagoons, there are regions with tropical rainforest, tropical semideciduous forest, tropical deciduous forest, thorn forest, xeric shrublands and deserts, oak forest, pine forest and cloud forest. However, most of the surface of the state is covered by xeric shrublands, and in second place by temperate oak, pine and cloud forests (Martínez-Morales et al.2007). 
Figure 1. Geographical location of Hidalgo state. A) Limits and physiographic provinces in Hidalgo state.

B) Hidalgo in Mexico.

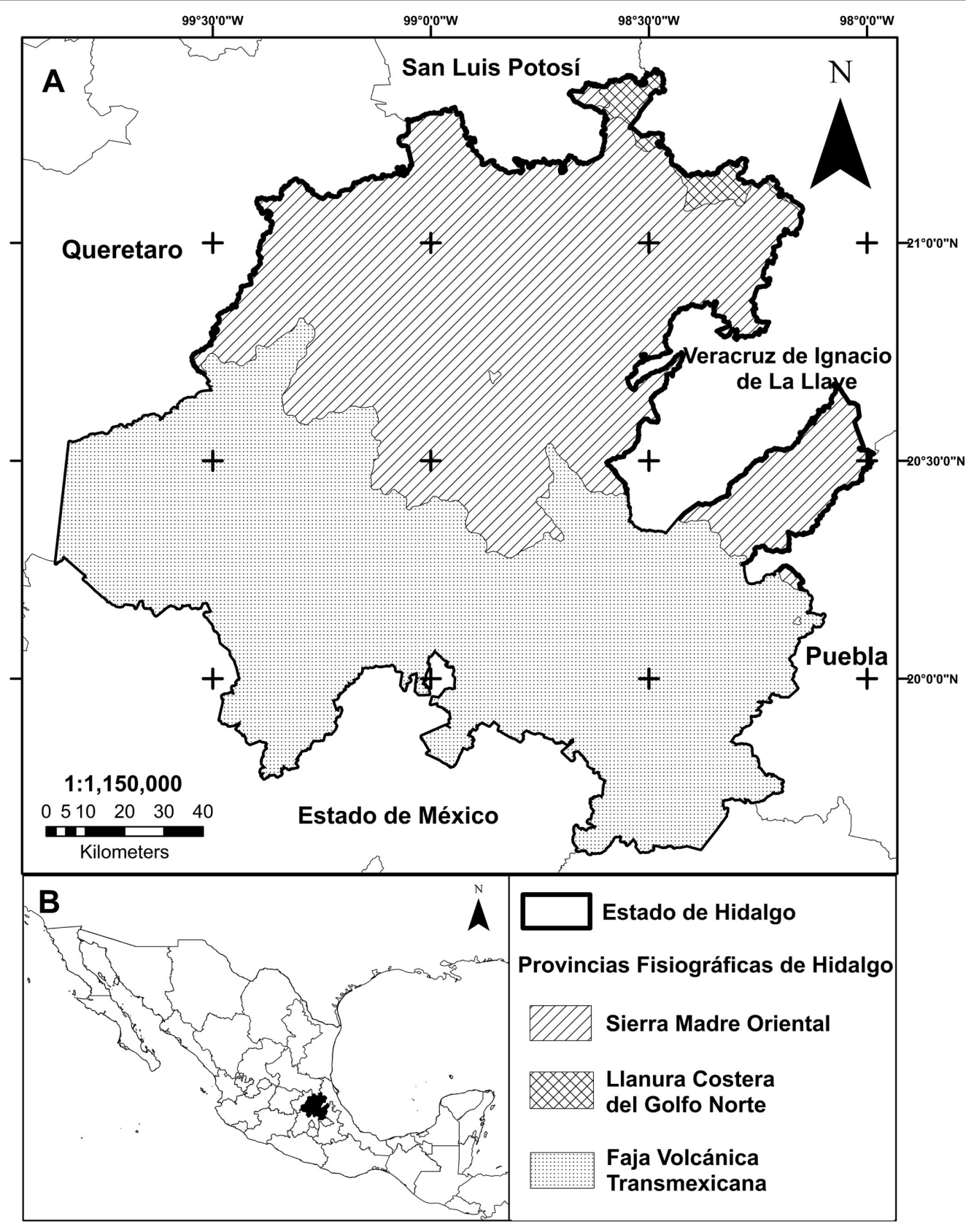

Materials and methods

This study was based on an analysis of the voucher specimens of oaks collected in Hidalgo and identified by the authors. In addition, collections of Fagaceae at ENCB, FCME, HUAP, HUMO, INEGI, MEXU, SLPM, XAL were revised and some of those at BH. All this allowed the distinction of morphological variation of the taxa by region and the elaboration of the corresponding descriptions.

The nomenclature of the species was considered according to the studies of Muller \& McVaugh (1972), Valencia-A. (2004), Valencia \& Flores-Franco (2006), including the revision of original descriptions, type observations (specimens or digital images consulted at <http:// plants.jtor.org $>$ and in some special cases, the International Code of Nomenclature for algae, fungi, and plants (McNeill et al. 2012) was also consulted. Morphological descriptions, altitudinal and geographic distribution are based on the collected specimens, field data taken by the 
authors and the information on the labels of the revised herbarium specimens. The figures are based on representative specimens of the species and photographs were taken during the expedition. All revised vouchers for each species are listed in the appendix of the present study.

\section{Results}

Fagus grandifolia subsp. mexicana and 43 species of Quercus are present in Hidalgo. 22 species belong to section Quercus (white oaks) and 21 to section Lobatae (red oaks).

Fagaceae Dumort. Anal. Fam. Pl. 11 y 12. 1829. Trees or shrubs mostly monoecious, with evergreen or deciduous foliage, tannins, buds with imbricate scales; the stipules generally deciduous and scarious. Leaves simple, alternate (whorled in Trigonobalanus), petiolate, pubescent at a young stage, the margin lobed, crenate, dentate, serrate or entire, with pinnate venation. Inflorescences unisexual or androgynous catkins; the male catkins capitate or spiked, the female catkins rigid or flexible with 1 to several cupules containing 1-3 (15) pistillate flowers. Staminate flowers with or without associated bracts, usually deciduous, tepals 3-6 (8); stamens (3) 6-12 (18) in each flower. The anthers dithecal, with longitudinal dehiscence, pistillodes often present resembling trichomes in the center. Pistillate flowers with calyx 4-6 connate or the sepals free, petals absent, 1-pistillate, the pistil 3-carpellate (or more), ovary inferior, locules as many as carpels, placentation axile, two ovules per locule, all of them aborting except one, styles as many as carpels, with dry stigma, staminodes present or absent. The fruit is a nut, sometimes winged, individually included or in 2-3 (15) groups in a cupule with multiple bracts, one seed per fruit, with membranous seed wall, the endosperm absent, the embryo straight with fleshy cotyledons (based on Nixon 1997a).

The family comprises 10 genera with 700 up to more than 1,000 species distributed in the temperate, subtropical and tropical regions of the Northern hemisphere (Nixon \& Crepet 1989, Govaerts \& Frodin 1998, Judd et al. 2002, Manos et al.2008). In Mexico there are 2 genera and 162 species (Valencia-A. 2004). Two genera and 44 species occur in the state of Hidalgo.

\section{Key to genera of Fagaceae in the state of Hidalgo}

1.- Cupules hemispheric, scales appressed, nut (acorn) globose, one per cupule. Buds globose, ovoid, broadly ovoid, ellipsoid or conical. Male catkins racemose Quercus 1.- Cupules four-valved, scales similar to spikes, nuts tri-angled and slightly winged, usually two per cupule. Buds fusiform. Male catkins semicapitular Fagus Fagus L. Sp. Pl. 2: 997. 1753. Deciduous trees; buds fusiform with imbricate scales; stipules prominent. Leaves with subcoriaceous blades, secondary veins not branched, parallel, arriving whole until the margin and continuing until the toothed tip. Inflorescences unisexual, axillary. Staminate flowers syntepalous, stamens 6-16 in each flower. Pistillate flowers two per cupule, polytepalous, carpels and styles 3 . Annual maturing fruits, cupules 4-valved with scales like spikes, slightly woody. Tri-angled nuts, slightly winged, two per cupule, included until maturity within the cupule, $x=12$ (based on Nixon 1997a).

Genus with 8 to 13 species distributed in mountainous temperate and subtropical regions of North America, Europe and Asia (Govaerts \& Frodin 1998, Williams-Linera et al. 2003, Rodríguez-Ramírez et al. 2013). In Hidalgo only one species is present.

Fagus grandifolia Ehrh. subsp. mexicana (Martínez) A. E. Murray. Kalmia 13: 6. 1983. Type: Mexico, Hidalgo, Zacualtipán, Zacatlamaya, Mts. near Zacualtipán, 1,800-1,900 m, Martínez (1940) 1,500 (holotype: MEXU!).

= Fagus mexicana Martínez.

Trees of 25-30 m tall; glabrous or glabrescent twigs with solitary trichomes and appressed with villous appearance, diameter of 0.7-1.1 mm, scars of scales on the base of the twigs; buds fusiform, (4) 10-14 mm long, glabrous, scales dull and lustrous. Mature leaves with petioles 2-4 mm long, glabrescent, unicellular trichomes and appressed towards the base of the petiole; blades ovate or lanceolate, papyraceous to subcoriaceous, (4) 6-9.5 × (1.5) 2.4-3.5 cm; base cu- 

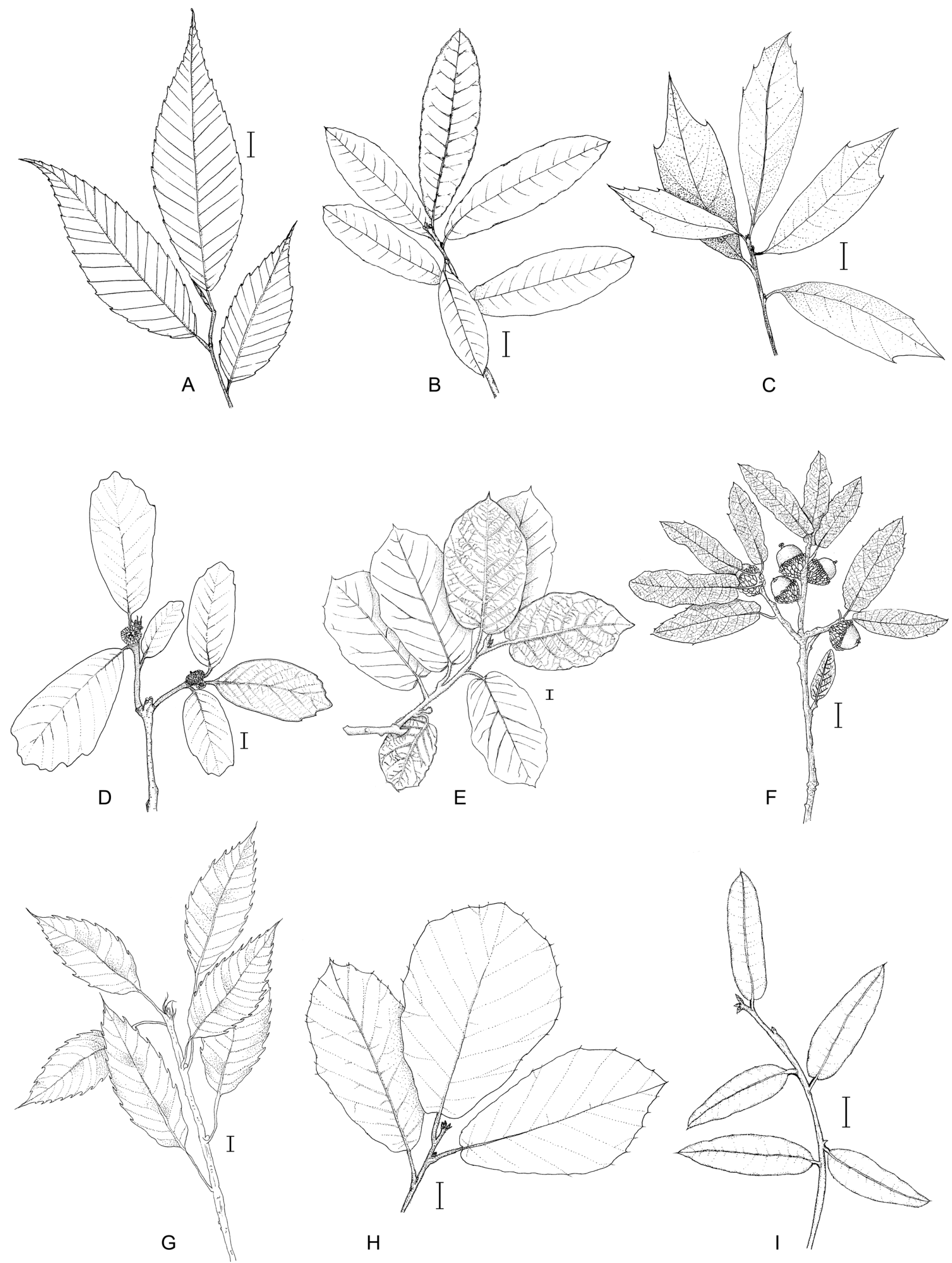

Figure 2. Illustrations of twigs with leaves. A) Fagus grandifolia subsp. mexicana. B) Quercus acherdophylla. C) Q. affinis. D) Q. ariifolia. E) $Q$. candicans. F) $Q$. castanea . G) $Q$. corrugata, H) $Q$. crassifolia. I) $Q$. crassipes. The scale in all cases corresponds to $1 \mathrm{~cm}$. 
neate to acute; margin with 9-15 short teeth on each side of the leaf; apex acuminate; secondary veins 9-15 on each side of the midvein, ascendant, straight and almost parallel; adaxial blade surface dull and glabrous, except for the midvein that preserves appressed acute unicellular trichomes, midvein slightly prominent, secondary veins and veinlets flat; abaxial blade surface glabrous or glabrescent, with appressed acute unicellular trichomes over the midvein and the base of the secondary veins. Fruits annual, cupules 4-valved, solitary at the end of a villous peduncle of 7-13 mm long $\times 1-1.5 \mathrm{~mm}$ wide, cupule valves woody, reddish-brown, lanceolate, 12-14 mm long $\times$ 6-7 mm wide, villous and hirsute, dehiscent at maturity; nuts two per cupule, glabrous, 14-17 mm long $\times 7-8 \mathrm{~mm}$ diameter, 3-angular and glabrous, slightly winged; exserted $1 / 4-1 / 5$ over the bracts (Figures $2 \mathrm{~A}$ and $7 \mathrm{~A}$ ).

Distribution and ecology. Fagus grandifolia subsp. mexicana is distributed in the Sierra Madre Oriental, in the states of Hidalgo, Nuevo León, Puebla, San Luis Potosí, Tamaulipas and Veracruz. Recently, Rodríguez-Ramírez et al. (2013) mentioned that it is extinct in Puebla and San Luis Potosí. It grows in level terrain, but more frequently on steep slopes up to $30^{\circ}$, on slopes with North exposition and obsidian derived, deep soils, with abundant organic matter. In Hidalgo it occurs in cloud forest and Fagus (beech) forest, associated with Magnolia schiedeana, Quercus affinis, Q. delgadoana, Q. hirtifolia, Q. meavei and Pinus sp.; at elevations from 1,800 to 2,050 m. Flowers open February and March; fruits mature in July and August.

Taxonomic comments. This taxon was originally described from Hidalgo as Fagus mexicana (Martínez 1940). The bigger fruits and cuneate base of the leaves were the main features that Martínez (op cit.) used to distinguish it from F. grandifolia. Little (1965) and Murray (1983) considered these features as insufficient to treat it at specific level, the former proposed it as a variety of Fagus grandifolia, while the latter considered it as a subspecies, which is its currently accepted status (Govaerts \& Frodin 1988). After examining the material from the study zone, the mentioned features used by Martínez (op cit.) to distinguish this taxon as a species were found to be not constant and even the fruit is smaller than that reported for $F$. grandifolia in the Flora of North America (Nixon 1997a). Also, the base of the leaves could be cuneate to acute, which coincides with the description of $F$. grandifolia for the same feature in Flora of North America (cuneate to subacute base).

This taxon can be easily distinguished from the rest of the Fagaceae in the study zone by its 4valved cupules, two nuts in each cupule, nuts 3-angular and shortly winged on the vertex, by the papyraceous leaves with parallel veins extending to the finely dentate margin, and the fusiform buds.

Quercus L. Sp. Pl. 2: 999. 1753. Trees or shrubs, evergreen or deciduous; buds globose, ovoid, ellipsoid or conical, scales imbricate; stipules persistent or deciduous. Leaves generally coriaceous or semicoriaceous, rarely papyraceous, the margin entire, lobed, crenate or dentate, mucronate or aristate; secondary veins somewhat parallel, brachydodromous or craspedodromous. Staminate inflorescences spicate (catkins), in axils of leaves. Staminate flowers syntepalous, stamens 6 (12). Pistillate inflorescences rigid. Pistillate flowers one per cupule, syntepalous, carpels and styles 3-6. Fruits maturing in one year (annual) or two years (biennial), cupules hemispheric, pateliform, turbinate or obconic, not valvate, covering the base of the acorn, scales imbricate, fused or not, or reduced to tubercles, acorns one per cup. $x=12$.

Genus of 400 up to 531 species, distributed mainly in the temperate regions of the Northern hemisphere (Nixon 1997b; Govaerts \& Frodin 1998). In Mexico there are more than 161 species (Valencia-A. 2004), with 43 species registered in the state of Hidalgo: 22 from Quercus section and 21 from section Lobatae.

\section{Dichotomous identification key for Quercus species}

1. Leaf blade margin entire ... 2

1. Leaf blade margin crenate, dentate or lobed ... 16

2. Leaf blade glabrous or the abaxial surface with tufts of trichomes in the axils of the secondary veins ... 3 

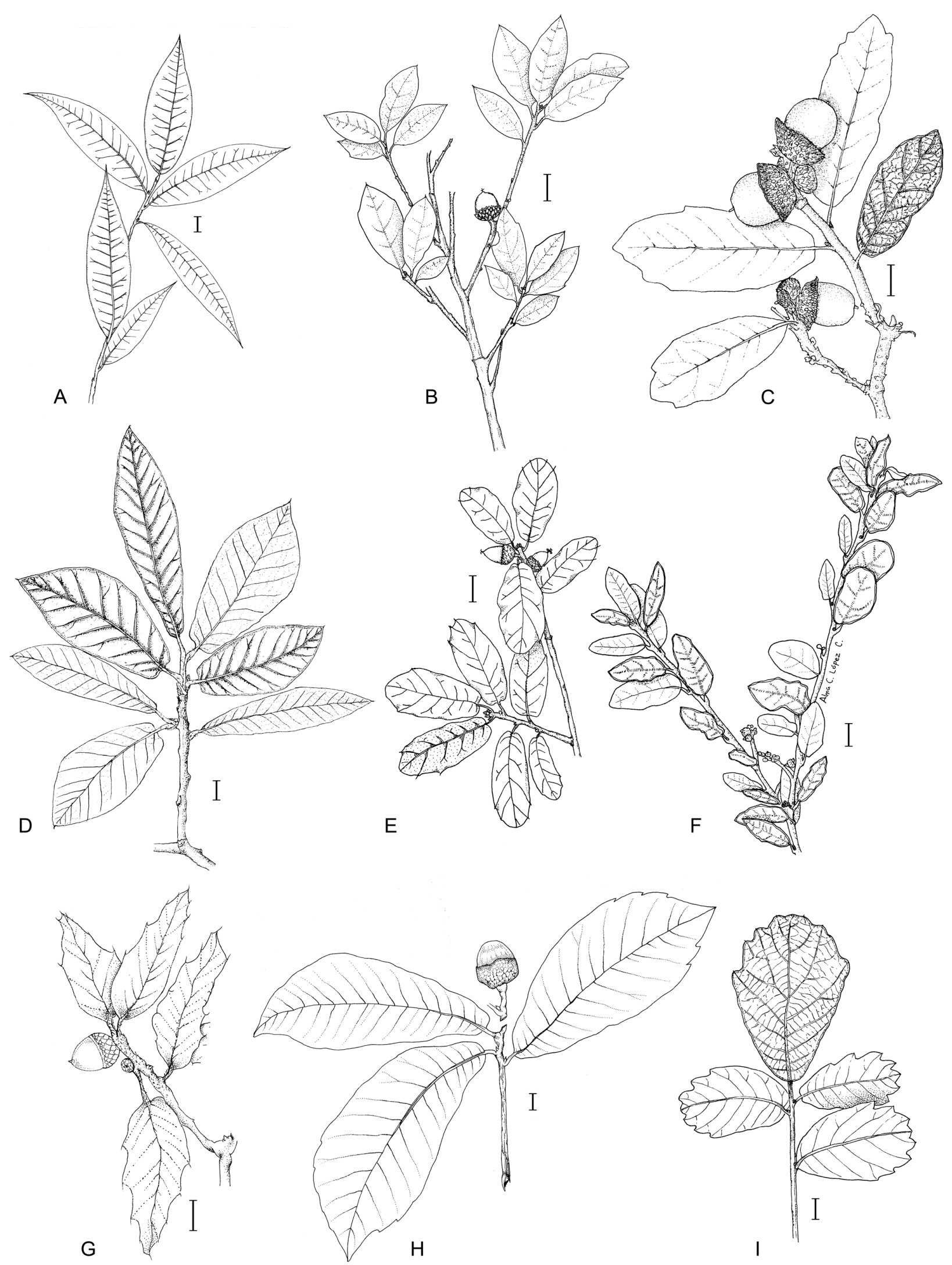

Figure 3. Illustrations of twigs with leaves. A) Quercus delgadoana. B) Q.depressa. C) Q.deserticola. D) Q.× dysophylla. E) Q.eduardi. F) $Q$. frutex. G) $Q$. furfuracea. H) $Q$. germana. I) $Q$. glabrescens. The scale in all cases corresponds to $1 \mathrm{~cm}$. 


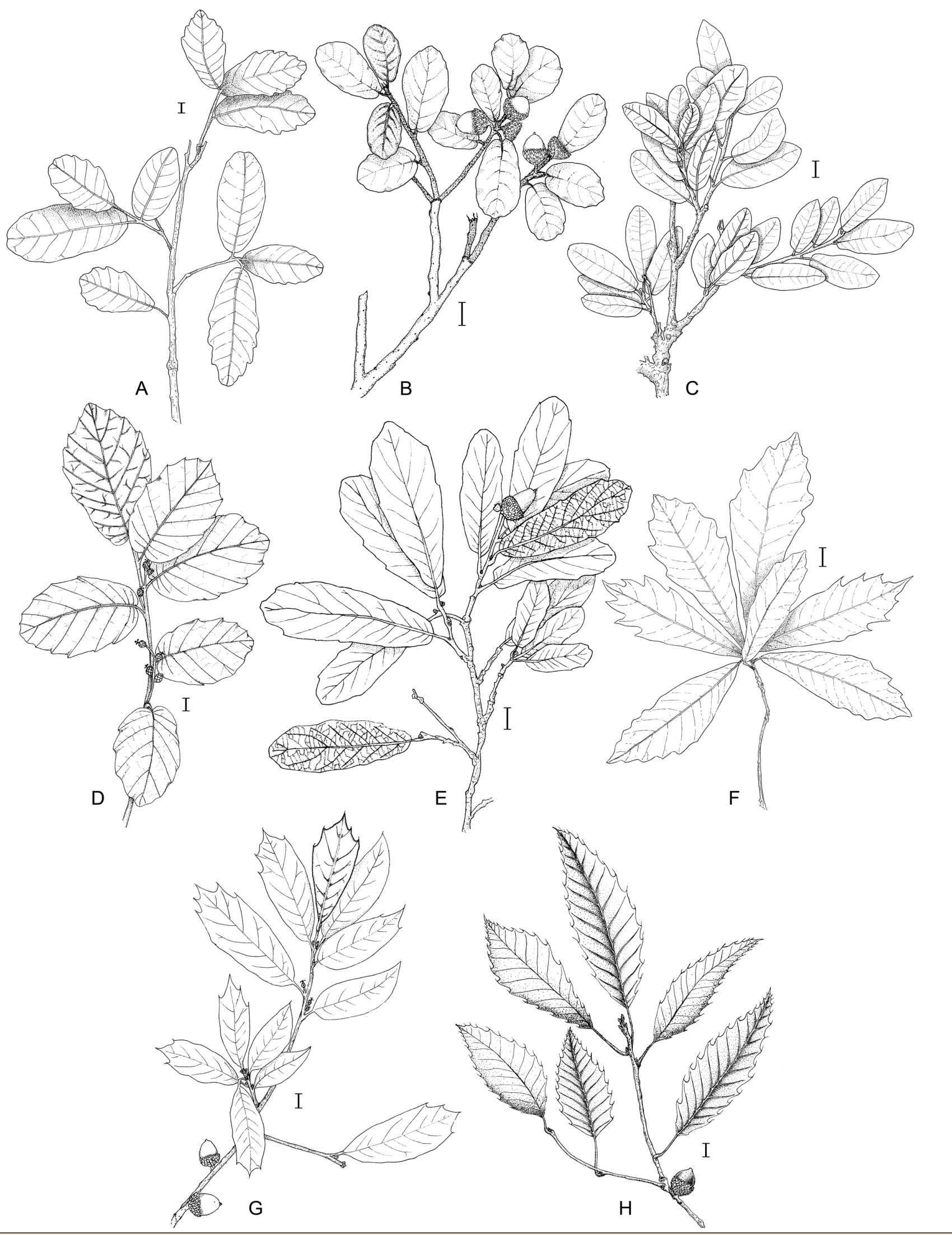

Figure 4. Illustrations of twigs with leaves. A) Quercus glaucoides. B) Q.greggii. C) Q. grisea D) Q. hirtifolia. E) Q. laeta. F) Q. lancifolia. G) Q. laurina. H) $Q$. meavei. The scale in all cases corresponds to $1 \mathrm{~cm}$. 
2. Leaf blade tomentose, at least the abaxial surface with trichomes uniformly covering the surface ... 11

3. Shrubs of 1.5-3 m, or small trees less than $6 \mathrm{~m} \mathrm{\ldots .} 4$

3. Trees of more than $10 \mathrm{~m} \mathrm{\ldots ..6}$

4. Leaves lustrous at least on the adaxial blade surface ... 5

4. Leaves dull on both surfaces ... Q. opaca

5. Leaves elliptic or elliptic-oblong; both surfaces lustrous. In temperate pine-oak forests. Elevations from 2,700 to $3,100 \mathrm{~m}$.... Q. depressa

5. Leaves oblong to lanceolate or narrowly elliptic; adaxial blade surface shiny; dull abaxially. Xerophilic shrubs from arid climates. Elevations from 1,800 to 2,200 m...Q. pringlei

6 . Mature leaf blades thick coriaceous or coriaceous; blade margin revolute ... 7

6. Mature leaf blades coriaceous, subcoriaceous or chartaceous; blade margin flat or almost flat ... 8

7. Leaf blades glaucous or grayish green; secondary veins from 9 to 20 on each side of the midvein; fruits biennial; acorns 18.3-22.9 mm long $\times 10.8-13 \mathrm{~mm}$ diameter. Elevations from 1,400 to $1,940 \mathrm{~m}$.... Q. delgadoana

7. Leaf blades not glaucous, green or yellowish green; secondary veins from 8 to 14 on each side of the midvein; fruits annual; acorns 8-12 mm long $\times 7-8.5 \mathrm{~mm}$ diameter. Elevations from 710 to $1,000 \mathrm{~m}$.... Q. sapotifolia

8. Secondary veins only slightly evident on the adaxial blade surface; blades subcoriaceous to chartaceous; leaf upperside lustrous... 9

8. Secondary veins evident on the adaxial blade surface; blades coriaceous; leaf adaxial surface not lustruous or slightly lustrous ... 10

9. Fruits annual (ripening in less than a year); twigs glabrescent to pubescent; leaf blade margin crispate; acorns ovoid to subspherical, 6-7(10) $\mathrm{mm}$ long $\times$ ca. $6 \mathrm{~mm}$ diameter $\ldots Q$. acherdophylla

9. Fruits biennial (ripening in two years); twigs glabrous; leaf blade margin flat (not crispate); acorns ovoid, 14-19 $\mathrm{mm}$ long $\times$ 8.6-9.6 $\mathrm{mm}$ diameter ... Q. pinnativenulosa

10. Secondary veins 7-10 on each side of the midvein; leaf base rounded, obtuse or truncate; apex acute or obtuse ... Q. laurina

10. Secondary veins $9-16$ on each side of the midvein; leaf base rounded, cuneate or decurrent; apex acute or acuminate and slightly curved towards one side ... Q. trinitatis

11. Shrubs of $0.3-3 \mathrm{~m} \ldots 12$

11. Trees of $5-20 \mathrm{~m} \mathrm{\ldots .} 14$

12. Abaxial blade surface without glandular trichomes ... 13

12. Abaxial blade surface with glandular trichomes ... Q. repanda

13. Abaxial blade surface with fasciculate stipitate trichomes ... Q. frutex

13. Abaxial blade surface with fasciculate sessile trichomes ... Q. microphylla

14. Leaves not glaucous, margin revolute; secondary veins impressed adaxially; abaxial blade surface covered with fasciculate trichomes ... 15

14. Leaves glaucous with flat margin; secondary veins smooth (not impressed) adaxially; abaxial blade surface covered with appressed stellate trichomes ... Q. grisea

15. Cupules with involute margin; abaxial blade surface with stipitate fasciculate trichomes, crispate $\ldots Q$. crassipes

15. Cupules with erect margin; abaxial blade surface with sessile, contorted, fasciculate trichomes ... Q. mexicana

16. Leaf blade margin toothed-aristate ... 17

16. Leaf blade margin toothed mucronate ... 30

17. Abaxial blade surface glabrous or with few trichomes in the axils of the secondary veins, or in the midvein vicinity ... 18

17. Abaxial blade surface with trichomes that cover the epidermis, densely or loosely ... 25

18. Leaf blade margin with 1-3 (5) aristate teeth on each side of the leaf, distributed towards the apex ... 19

18. Leaf blade margin with 5-7 aristate teeth on each side of the leaf, distributed towards the base or in the distal $2 / 3 \ldots 22$ 
19. Adaxial blade surface rugose, the veins impressed ... 20

19. Adaxial blade surface not rugose, smooth or almost so... 21

20. Fruits annual; cupules 3-7(8) mm high; acorns 9-12 $\times$ 8-11 mm; secondary veins 8-13 on each side of the midvein; abaxial blade surface with bullate epidermis ... Q. castanea

20. Fruits biennial; cupules 9.5-11.5 mm high; acorns 13-17.5 × 10.6-12 mm; secondary veins 11-16 on each side of the midvein; abaxial blade surface with papillose epidermis ... Q. rysophylla

21. Abaxial blade surface without glandular trichomes; leaf base cuneate to acute, secondary veins straight ...Q. affinis

21. Abaxial blade surface with glandular trichomes; leaf base rounded, obtuse or truncate; secondary veins curved ... Q. laurina

22. Secondary veins impressed adaxially, 13-17 on each side of the midvein; cupules (13)18-23 mm diameter; fruits biennial ... Q. meavei

22. Secondary veins smooth or slightly prominent adaxially, 6-12 on each side of the midvein; cupules 8.5-18 mm diameter; fruits annual ... 23

23. Adaxial blade surface scarcely shiny, or dull; blade margin with (3) 6-8 short teeth; cupules hemispheric or obconic; acorns 8.5-13 ×6.2-10 mm ... 24

23. Adaxial blade surface shiny; blade margin with 9-12 large teeth; cupules turbinate; acorns $12.5-18 \times 10-13.5 \mathrm{~mm} \ldots$.. Q paxtalensis

24. Twigs and petioles pubescent to tomentose, acorns $10.5-12 \mathrm{~mm}$ diameter ... Q. furfuracea

24. Twigs and petiololes glabrate, acorns 6.2-9.9 mm diameter ... Q. sartorii

25 . Abaxial blade surface velutinous, with appressed stellate trichomes ... Q. candicans

25 . Abaxial blade surface pubescent or lanuginose, with fasciculate trichomes ... 26

26. Adaxial blade surface with impressed veins giving a rugose appearance; abaxial blade surface lanuginose ... 27

26. Adaxial blade surface with smooth or convex veins, without rugose appearance; the underside pubescent ... 29

27. Abaxial blade surface with fasciculate sessile trichomes, glandular trichomes present or absent; fruits annual ... Q. castanea

27. Abaxial blade surface with fasciculate stipitate trichomes, glandular trichomes present; fruits biennial ... 28

28. Leaves 1.4-1.8 times longer than wide; secondary veins 7-10 on each side of the midvein; peduncle of fruit 10.4-16.9 mm long; cupules hemispheric; acorns 6.6-10.7 mm diameter ... $Q$. crassifolia

28. Leaves 2.5-3.5 times longer than wider; secondary veins 9-16 on each side of the midvein; peduncle 1-5 mm long; cupules turbinate; acorns 10-14 mm diameter $\ldots Q . \times$ dysophylla

29. Abaxial blade surface with fasciculate sessile, contorted trichomes; cupules 7-10 mm diameter ... Q. eduardi

29. Abaxial blade surface with fasciculate stipitate trichomes, crispate; cupules $12-13 \mathrm{~mm}$ diameter ... Q. hirtifolia

30. Abaxial blade surface glabrous or with few loosely distributed trichomes; epidermis exposed ... 31

30. Abaxial blade surface tomentose; epidermis hidden by the trichomes ... 38

31. Leaf blade margin with teeth distributed from above the base; on distal half or $3 / 4 \ldots 32$

31. Leaf blade margin with teeth distributed only on the distal $1 / 4$ or towards the apex ... 33

32. Trees 15-30 m; leaves 7-17.5 cm long; blade margin with 8-16 teeth on each side of the leaf; cupules $15-22 \times 4-10 \mathrm{~mm}$; acorns $20-23 \times 15-20 \mathrm{~mm} \ldots$... corrugata

32. Shrubs of 15-75 cm; leaves 2.5-4.2 cm long; blade margin with 2-5 teeth on each side of the leaf; cupules 12-14 × 4-6 mm; acorns 13-16 × 9-11 mm ... Q. tinkhamii

33. Abaxial blade surface glaucous; epidermis waxy ... 34

33. Abaxial blade surface not glaucous; epidermis nor waxy ... 36

34. Shrubs or small trees 1.5-3 m; acorns 9-15 ×6-9 mm ... Q. sebifera

34. Trees more than $3 \mathrm{~m}$; acorns $17-40 \times 9.28 \mathrm{~mm} \ldots 35$

35. Petioles 14-20 mm long; acorns 17-18 mm long; fruits commonly on peduncles located axillary to the leaves ... Q. polymorpha 


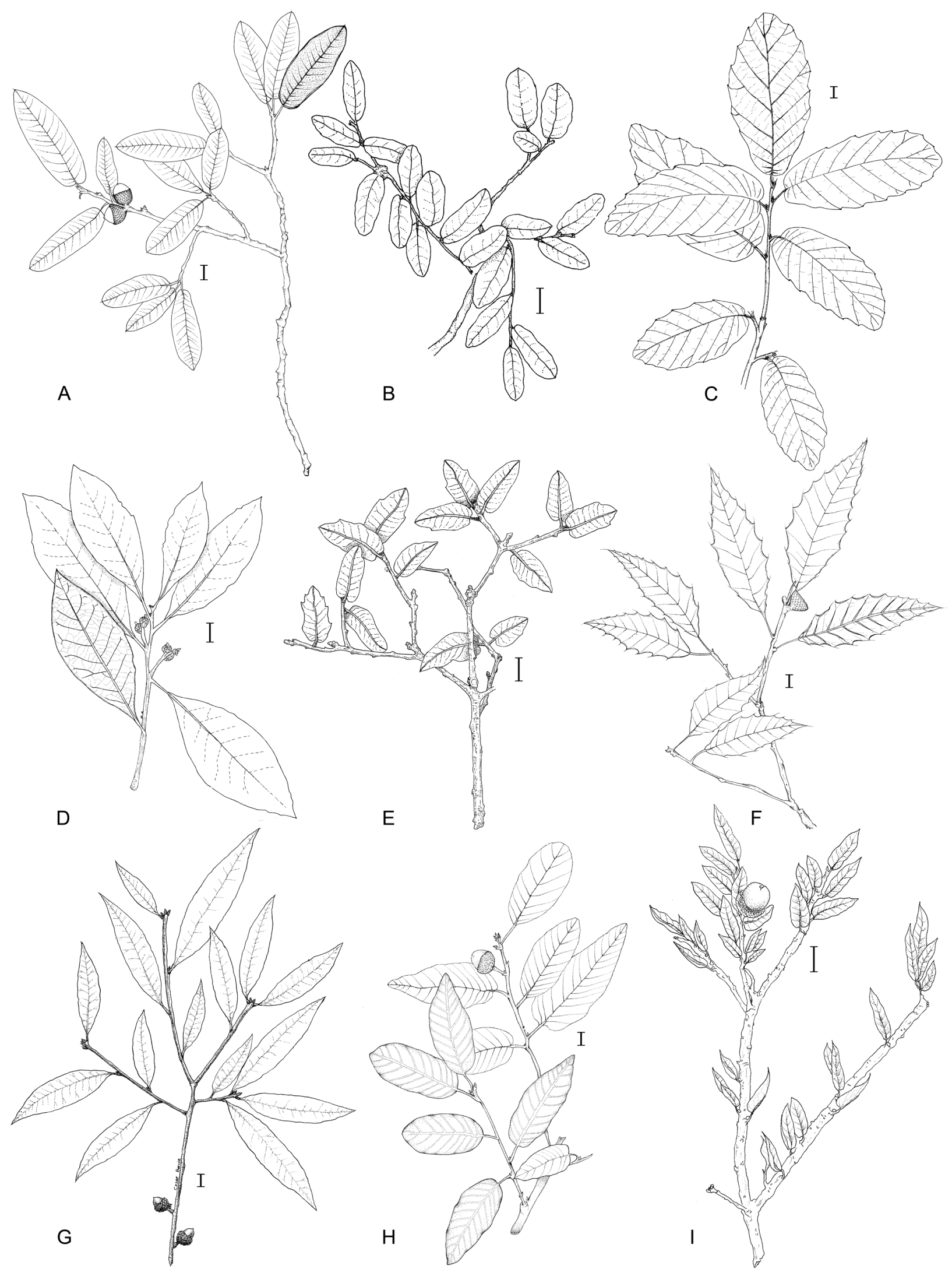

Figure 5. Illustrations of twigs with leaves. A) Quercus mexicana. B) $Q$. microphylla. C) $Q$. obtusata. D) $Q$. oleoides. E) $Q$. opaca. F) $Q$. paxtalensis. G) $Q$. pinnativenulosa. H) $Q$. polymorpha. I) $Q$. pringlei. The scale in all cases corresponds to $1 \mathrm{~cm}$. 


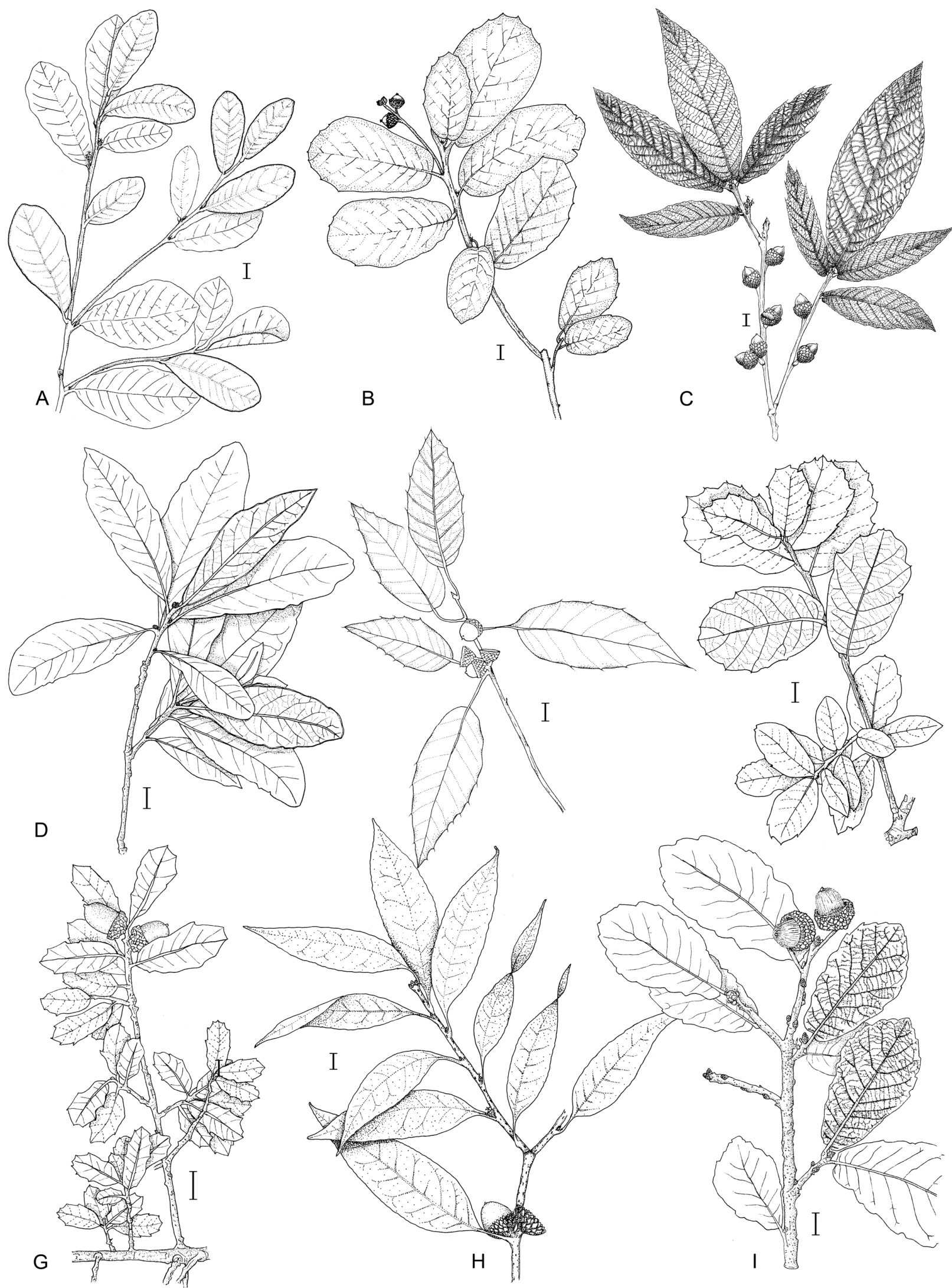

Figure 6. Illustrations of twigs with leaves. A) Quercus repanda. B) $Q$. rugosa. C) $Q$. rysophylla. D) $Q$. sapotifolia. E) $Q$. sartorii. F) $Q$. sebifera. G) Q. tinkhamii. H) Q. trinitatis. I) Q.xylina. The scale in all cases corresponds to $1 \mathrm{~cm}$. 
35. Petioles 3-6 mm long; acorns $28-40 \mathrm{~mm}$ long; fruits commonly on peduncles located at the apex of the last twigs ... Q. germana

36. Adaxial blade surface glaucous, slightly lustrous, midvein and secondary veins impressed; abaxial blade surface with fasciculate sessile trichomes, contorted and acute unicellular trichomes appressed over the midvein; blade margin revolute ... 37

36. Adaxial blade surface glaucous and dull, midvein and secondary veins at the same level as the leaf surface; abaxial blade surface with few stellate trichomes, unicellular trichomes absent, blade margin not revolute ... Q. glaucoides

37. Leaves oblanceolate to elliptic; secondary veins 10-14 on each side of the midvein; adaxial blade surface not rugose $\ldots Q$. lancifolia

37. Leaves broadly elliptic, broadly oblong or elliptic-oblong; secondary veins 6-10 on each side of the midvein; adaxial blade surface rugose $\ldots Q$. glabrescens

38. Adaxial blade surface not rugose, with smooth or prominent veins; abaxial blade surface with stellate trichomes ... 39

38. Adaxial blade surface rugose with impressed veins; abaxial blade surface with fasciculate trichomes ... 40

39. Shrubs $15-70 \mathrm{~cm}$; abaxial blade surface with stellate trichomes, lax or lightly distributed; the teeth with acute mucro similar to a small tip; blade 1.5-3.5 times longer than wide ... $Q$. tinkhamii

39. Trees 15-25 m; abaxial blade surface with stellate appressed trichomes covering the whole surface, appearently glabrous at first sight; the teeth with soft or slightly pointed mucro; blade 1.9-2.5 times longer than wide ... Q. oleoides

40. Abaxial blade surface without glandular trichomes ... 41

40. Abaxial blade surface with glandular trichomes ... 42

41. Abaxial and adaxial blade surfaces with fasciculate stipitate trichomes ... Q. deserticola 41. Adaxial blade surface lacking trichomes or only preserving limited sessile fasciculate trichomes towards the base of the midvein and margin; abaxial blade surface with sessile fasciculated trichomes ... Q. laeta

42. Leaves considerably rugose and rigid; teeth of the margin with acute mucro; abaxial blade surface covered with fasciculate trichomes, overlapping and covering the epidermis; glandular trichomes present or absent ... 43

42. Leaves slightly rugose; teeth of the margin with small mucro; abaxial blade surface covered with fasciculate and glandular trichomes ... 45

43. Abaxial blade surface pubescent to glabrescent; teeth of leaves with acute mucro resembling a tip; leaves convex ... Q. rugosa

43. Abaxial blade surface lanuginous, teeth of leaves rhombic with thick mucro; leaves with revolute margin, but not convex ... 44

44. Trees of 7-20 m; blades coriaceous; blade margin revolute or slightly revolute; blades of 6.5$12 \mathrm{~cm}$ long; secondary veins $7-12$ on each side of the midvein ... Q. ariifolia

44. Shrubs or trees up to $6 \mathrm{~m}$; blades rigid-coriaceous; blade margin strongly revolute and broadly crispate; blades $2.5-6.5 \mathrm{~cm}$ long; secondary veins $5-8$ on each side of the midvein ... Q. greggi

45. Twigs glabrous to glabrescent; abaxial blade surface glabrescent; blade margin not revolute, blade coriaceous or subcoriaceous; fruits in groups of 3-5 ... Q. obtusata

45. Twigs tomentose; abaxial blade surfaces pubescent; blade margin slightly revolute; blade coriaceous; fruits in groups of 1-5 ... Q.xylina

Quercus acherdophylla Trel., Mem. Natl. Acad. Sci. 20: 183. 1924. Type: Mexico. Puebla, Honey Station, Pringle 1008 (isotypes: ENCB, MEXU!).

Trees $15-20 \mathrm{~m}$ tall; twigs $0.8-1.5 \mathrm{~mm}$ in diam., glabrescent to puberulent, gray to brown, with tiny multiradiate stellate trichomes, lenticels inconspicuous; buds ovoid, 1.5-2.8 (4) mm long, scales broadly ovate, glabrate, amber to gray, margin ciliate; stipules deciduous. Mature leaves with petioles $2-7 \times 0.5-1.5 \mathrm{~mm}$, glabrescent with some tiny multiradiate stellate trichomes; blades chartaceous to subcoriaceus, elliptic, elliptic-lanceolate or oblong, 2.8-6.6 (-9) $\times(0.8) 1.3$ $2.7(3.7) \mathrm{cm}, 2.5-4.4$ times longer than wider; base rounded, obtuse or cuneate; margin entire, 

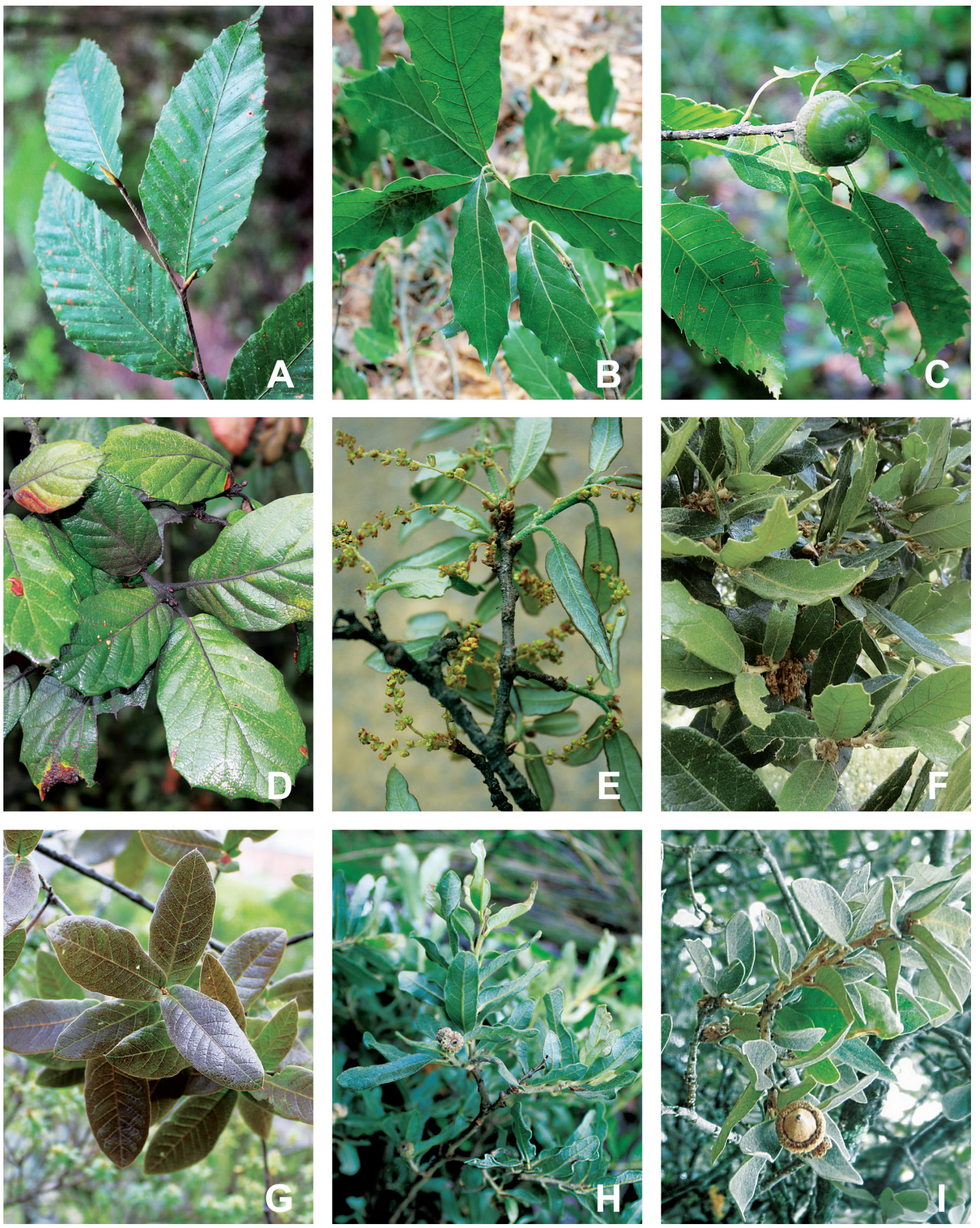

Figure 7. A) Fagus grandifolia subsp. mexicana. B) Quercus affinis. C) Q. corrugata. D) Q.crassifolia. E) Q. crassipes. F) Q. deserticola. G) $Q . \times$ dysopylla. H) $Q$.frutex. I) $Q$. grisea. 

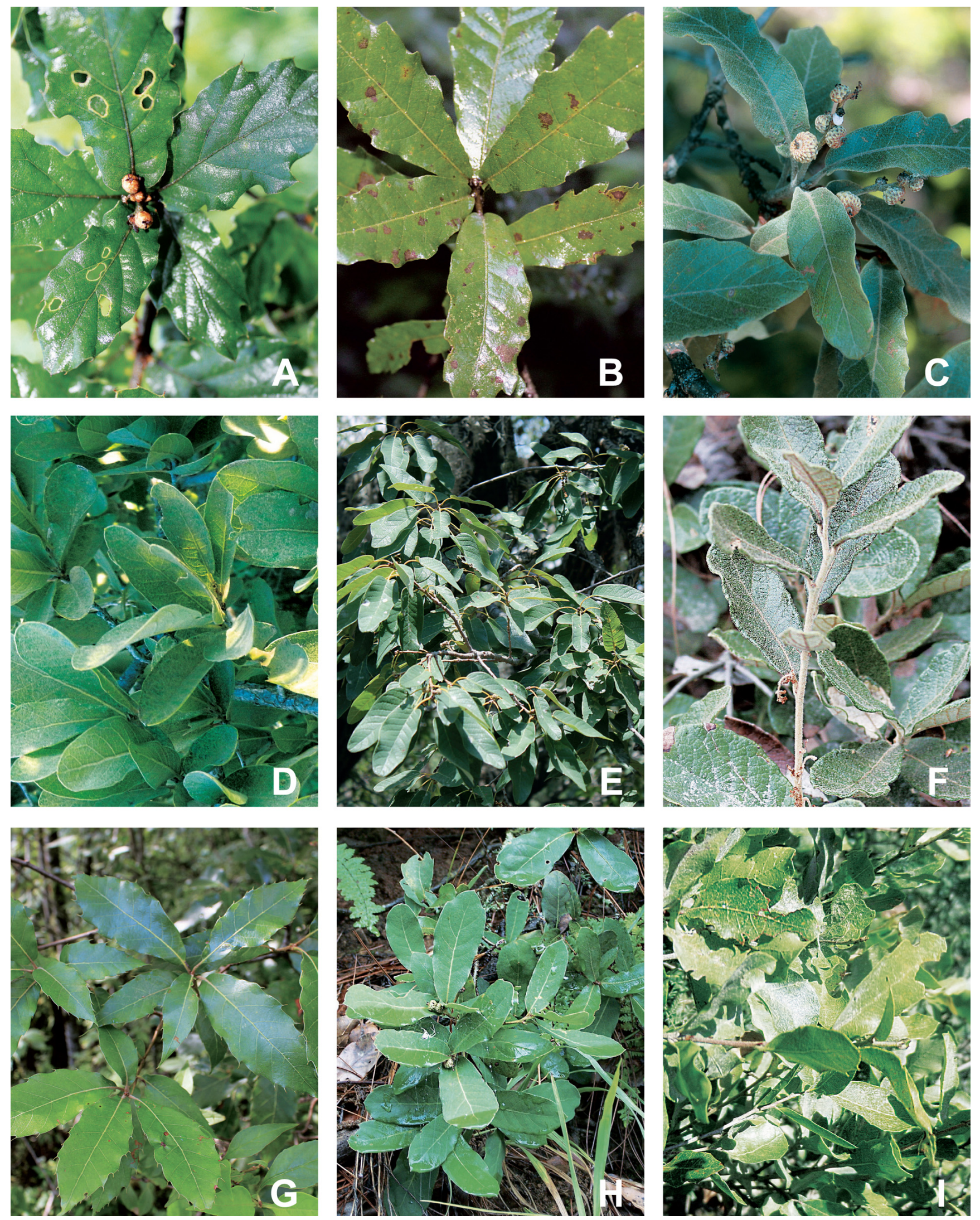

Figure 8. A) Quercus hirtifolia. B) $Q$. lancifolia. C) $Q$. xylina. D) $Q$. opaca. E) $Q$. polymorpha. F) $Q$. repanda. G) $Q$. sartorii. H) $Q$. sebifera. I) Q. tinkhamii. 
slightly crispate or flat; apex acute to rounded, tip aristate; secondary veins 8-16 on each side of the midvein, ascending and moderately curved, branching and anastomosing in the distal third; adaxial blade surface mostly glabrous but retaining few stellate and multiradiate trichomes near the midvein, secondary and tertiary veins flat or slightly impressed; abaxial blade surface glabrous to glabrescent with tufts of fasciculate stipitate trichomes in the axils of the secondary veins and scarce multiradiate trichomes on the flanks of midvein and secondary veins, epidermis slightly papillose, veins prominent, pale to slightly yellowish. Fruits annual, solitary on a glabrescent peduncle 3-11 mm long; cupules hemispheric to slightly turbinate, 7-11 mm diam. $\times$ 4-8 mm tall, margin erect, scales smooth, appressed, apex rounded, tomentose; acorns ovoid to globose, 6-7 (10) $\mathrm{mm}$ long $\times$ ca. $6 \mathrm{~mm}$ diam., included $1 / 2$ to $1 / 3$ of their total length in the cupule (Figure 2B).

Distribution and ecology. Endemic to Mexico, in the Sierra Madre Oriental; in the states of Hidalgo, Oaxaca, Puebla and Veracruz. In Southeastern Hidalgo state, Quercus acherdophylla occurs in moist oak forests, cloud forests and riparian forests. Associated with Quercus affinis; at elevations from 2,100 to 2,200 m. Flowering time for Hidalgo state is unknown; Fruits mature in October and November.

Taxonomic comments. Quercus acherdophylla can be confused with $Q$. laurina Bonpl. and $Q$. affinis Scheidw., especially when they lack fruits, as they all present lanceolate and glabrescent leaves; however $Q$. acherdophylla can be easily separated based on its annual fruits, chartaceous to semicoriaceus blades, entire blade margin and acute to rounded apex; whereas that $Q$. laurina and $Q$. affinis have fruits that mature in two years, coriaceous blades, the blade margin commonly is aristate-dentate near the apex, and the apex usually is acute.

Quercus affinis Scheidw., Hort. Belge 4:321. 1837. pl. 17. Syntype: Mexico. [Hidalgo], cést aux environs de Regla et de Istula, á cinq lieues de Real-del-Monte.

= Quercus nitens M. Martens et Galeotti. Q. nitens var. subintegra A. DC.Q.affinis f. subintegra Trel. Q. commutata Liebm. Q. affinis f. commutata Trel.

Trees 11-18 m tall; twigs 1-2.5 mm diam., terete, sometimes furrowed, glabrous or glabrate, brown, lenticels inconspicuous; buds conical or ovoid, 2-4 (5.5) mm long, scales ovate to slightly triangular, glabrous, amber, margin ciliate; stipules deciduous. Mature leaves with petioles 5-13 × 0.5-1 (1.5) mm, glabrous to glabrescent; blades coriaceus, lanceolate, elliptic or ellipticlanceolate, $3-13 \times 1-3 \mathrm{~cm}, 3.1-3.5$ times longer than wider; base acute or cuneate; margin with 1-3 (5) aristate teeth located in the distal half of the blade, slightly thick; apex acute, aristate; secondary veins 5-9 on each side of the midvein, ascending, straight, the central veins with an angle of divergence more acute than the lower and upper, branching and anastomosing in the distal third or those ending in a tooth continuing towards the arista; adaxial blade surface glabrous or puberulent, shiny, with scarce tiny stellate trichomes towards the base of the midvein, primary, secondary and tertiary veins flat or slightly prominent; abaxial blade surface glabrous or with tufs of fasciculate stipitate trichomes in the axils of the secondary veins, midvein and secondary veins slightly prominent, epidermis flat. Fruits biennial, 1-3 on a glabrous peduncle 5-12 mm long; cupules hemispheric, 10-13 mm diam. $\times 7-9 \mathrm{~mm}$ tall, margin erect, scales smooth, appressed, sparingly pubescent; acorns ovoid, glabrous 13-18 mm long $\times$ ca. $12 \mathrm{~mm}$ diam., included $1 / 2$ to $1 / 3$ of their total length in the cupule (Figures $2 \mathrm{C}$ and $7 \mathrm{~B}$ ).

Distribution and ecology. Endemic to Mexico, in the Sierra Madre Oriental and at the eastern of the Transmexican Volcanic Belt; in the states of Guanajuato, Hidalgo, Nuevo León, Oaxaca, Puebla, Queretaro, San Luis Potosi, Tamaulipas and Veracruz. Abundant and widely distributed in southeastern Hidalgo, in oak-pine forests, humid oak forests, juniper forests and cloud forests, on river banks. Associated with Abies sp., Alnus sp., Juniperus sp., Quercus candicans, $Q$. castanea, $Q$. crassifolia, $Q$. glabrescens, $Q$. mexicana, $Q$. laeta, $Q$. laurina, $Q$. polymorpha, $Q$. meavei and Pinus patula; at elevations from 1,200 to 2,720 (2,991) m. Flowering in February and March; fruits mature from August to November.

Taxonomic comments. Quercus affinis can be confused with $Q$. acherdophylla, Q. laurina and $Q$. depressa Bonpl., but it is distinguished from $Q$. laurina by its conic buds, rounded, acute or cuneate base of the blades, the straight secondary veins and the lack of amber glandular trichomes on the abaxial blade surface; $Q$. laurina has globose to ovoid buds, leaves with 
a rounded, obtuse or truncate base, moderately curved secondary veins and amber glandular trichomes on the abaxial blade surface; $Q$. depressa has a shrubby habit and has smaller and brighter leaves compared with $Q$. affinis. Differences from Q. acherdophylla are recorded in the taxonomic comments of that species.

Quercus ariifolia Trel., Mem. Nat. Acad. Sci. 20:74, pl. 97. 1924. Type: Mexico. San Luis Potosi, Alvarez, sept. 1902, Palmer 82 (holotype: MO; isotype: US!).

Trees 7-15 (-21) $\mathrm{m}$ tall; twigs 2-3.9 $\mathrm{mm}$ in diam., gray, tomentose to glabrescent with fasciculate sessile trichomes, lenticels inconspicuous and pale; buds ovoid, sometimes conical, 2.23.14 (5) mm long, scales ovate to broadly ovate, glabrous or glabrescent, amber to brown, margin ciliate; stipules deltoid to narrowly lanceole, (3.29) 5.14-7.42 mm long, strigose, persisting at the apex of the twigs. Mature leaves with petioles (4.6) $6.11-10.31 \times 1.2-2.47 \mathrm{~mm}$, tomentose to glabrescent, with fasciculate sessile trichomes, the rays crispate; blades coriaceus, obovate, elliptic, rarely ovate, (4) 6.5-12 × 3-5.7 (8) cm, 1.5-2.4 times longer than wider; base rounded to subcordate; margin revolute, with 2-4 mucronate teeth on each side of the blade; apex obtuse to rounded; secondary veins 7-9 (12) on each side of the midvein, ascending, straight or moderately curved, branching and anastomosing near of margin, otherwise continuing into the tooth if present until the mucro; adaxial blade surface prominently rugose, dull or somewhat shiny, glabrous or glabrate with fasciculate sessile trichomes along the midvein, primary, secondary veins and veinlets impressed; abaxial blade surface tomentose to lanuginous, with whitish fasciculate sessile trichomes, the rays long, crispate and intertwined, hiding the epidermis bullate and papillose, with or without hyaline or yellowish glandular trichomes, midvein and secondary veins prominent, yellowish or slightly brown. Fruits annual, 1-5 (9) on a peduncle (6) 20-70 mm long, sparingly covered with fasciculate sessile trichomes; cupules hemispheric 12-13 (15) mm diam. $\times$ 6-8.5 mm tall, margin erect, scales smooth, loosely appressed, triangular, apex acute, slightly canescent; acorns ovoid to globose, glabrous, $10-15 \mathrm{~mm}$ long $\times 9-15 \mathrm{~mm}$ diam., included $1 / 2$ to $1 / 4$ of their total length in the cupule (Figure 2D).

Distribution and ecology. Endemic to Mexico, in the Sierra Madre Oriental; in the states of Hidalgo, Nuevo León, Puebla, Queretaro, San Luis Potosi and Veracruz. In Hidalgo in oak forest, in the border of cloud forests, oak-pine forest, and arid tropical scrub. Associated with Abies religiosa, Juniperus sp., Quercus crassipes, $Q$. crassifolia, $Q$. affinis and Pinus patula; at elevations from 1,900 to 2,890 m. Flowering in April and May; fruits mature in September and October.

Taxonomic comments. Quercus ariifolia can be confused with $Q$. rugosa and $Q$. greggii. However it can be distinguished by its whitish-lanuginous abaxial blade surface and because it generally lacks amber glandular trichomes, while $Q$. rugosa and $Q$. greggii always have abundant amber glandular trichomes on the abaxial blade surface. Additionally the leaves of $Q$. rugosa are usually concave abaxially, while those of Q. ariifolia are not. Quercus greggii can be distinguished by its coriaceous-rigid leaves and the yellowish-tomentose abaxial blade surface. Q. ariifolia was proposed as a synonym of Q. rugosa (Muller 1997, Nixon \& Muller 1997, Valencia-A. 2004, Valencia \& Flores-Franco 2006), but there are differences such as those above described, that allow us to recognize these as two distinct species. Also we point out that the species was validly published as $Q$. ariaefolia Trel., but the orthographically correct spelling is Q. ariifolia Trel.

Quercus candicans Née, Anales Ci. Nat: 3: 277(1801). Type: Mexico. Guerrero, Cerca de Tixtla, Née s.n. (syntype: MA!).

$=$ Quercus calophylla Schltdl. et Cham. Q. alamo Benth. Q. calophylla f. alamo (Benth.) Trel. Q.acuminata M. Martens et Galeotti. Q. calophylla f. acuminata (M. Martens et Galeotti) Seem. ex Trel. Q. intermedia M. Martens et Galeotti. Q. calophylla f. intermedia (M. Martens et Galeotti) Seem. ex Trel. Q. umbrosa Endl. Q. flavida Liebm. Q. calopylla f. flavida (Liebm.) Trel. Q. candicans f. michoacana Trel. Q. calophylla f. schiedeana Trel. Q. calophylla f. willdenowii Trel. $Q$. candicans f. incurva Trel. $Q$. candicans var. alligata Trel.

Trees 15-25 (30) m tall; twigs (1.6) 2-3.5 mm in diam., furrowed, densely pubescent, indument yellowish, with stellate trichomes and fasciculate sessile trichomes, lenticels not visible; buds ovoid to long-ovoid, (2.3) 3-5 (7) mm long, scales broadly ovate, the basal scales reddish 
to brown, almost glabrous, margin entire, the superior scales golden and strigulose with margin ciliate; stipules deciduous or not, linear to narrowly lanceolate 10-15 mm long. Mature leaves with petioles $17.3-43.3 \times 1.2-1.8(2.3) \mathrm{mm}$, densely pubescent, indument slightly yellowish to pale with stellate and fasciculate sessile trichomes; blades coriaceus to subcoriaceus, obovate, (5) 8-20 (27) $\times(2.5)$ 4-12 (16) cm, 1.5-2.5 times longer than wider; base subcordate, subtruncate, rounded or sometimes decurrent; margin slightly thick, flat, with 5-8 aristate teeth on each side of the blade, located in the distal half or distal quarter of the blade, teeth sometimes very short and sometimes with two aristae to each tooth, otherwise only aristate (without teeth); apex obtuse or apiculate, aristate; secondary veins (6) 8-12 (15) on each side of the midvein, ascending and straight continuing directly into the tooth and arista if present, otherwise bifurcating near the margin; adaxial blade surface dark-green, shiny, glabrous or glabrate with persistent stellate trichomes along the midvein, primary, secondary veins and veinlets barely impressed and pale; abaxial blade surface densely pubescent, indument whitish to pale, with stellate appressed trichomes, secondary veins and veinlets prominent, yellowish, contrasting with surface, epidermis bullate and papillose. Fruits biennial, 1-3 on a puberulent peduncle 6.5-15.5 mm long; cupules hemispheric, 15.5-23.5 mm diam. $\times$ 9.2-15 mm high, scales smooth, canescent; acorns ovoid to broadly ovoid, 15.3-21.5 mm long $\times 12.8-19 \mathrm{~mm}$ diam., with sparse whitish tomentum at the apex, almost glabrous towards the base, included $1 / 2$ to $3 / 4$ of their total length in the cupule (Figure $2 \mathrm{E}$ ).

Distribution and ecology. Widely distributed in Mexico, in the Sierra Madre Oriental, Transmexican Volcanic Belt, Sierra Madre Occidental and the Sierra Madre del Sur; in the states of Chiapas, Ciudad de México, Colima, Durango, Guanajuato, Guerrero, Hidalgo, Jalisco, Mexico, Michoacán, Morelos, Nayarit, Oaxaca, Puebla, San Luis Potosí, Sinaloa, Sonora, Tlaxcala and Veracruz; reaching Guatemala. In Hidalgo state in cloud forests, pine-oak forests, oak forests, pine forest. Asociated with Baccharis sp., Buddleja sp., Pinus teocote, Prunus sp., Quercus affinis and $Q$. furfuracea, in deep red soils, slightly sandy, preferably near streams or in ravines; at elevations from 1,710 to 2,400 m. Flowering in March and April; fruits mature from July to September.

Taxonomic comments. Quercus candicans has leaves widely variable in form; however it can be distinguished easily by its constant and fundamental characters: the blades are coriaceous to subcoriaceous, with appressed stellate trichomes on the abaxial blade surface, the leaves present a bifacial appearance with dark-green adaxial surface and whitish to pale abaxial surface, the buds are ovoid to long-ovoid with golden and strigulose superior scales, as well as a robust fruit.

Quercus castanea Née, Anales Ci. Nat. 3: 276. 1801. Type: Mexico. Hidalgo. De Hidalgo a Guanajuato, Née s.n. (syntypes: MA!).

= Quercus mucronata Willd. Q. pulchella Bonpl. Q. lanigera M. Martens et Galeotti. $Q$. axillaris Fourn. ex Trel. Q. subcrispata Trel. Q. circummontana Trel. Q. serrulata Trel. $Q$. alamosensis Trel. Q. rossii Trel. Q. tepoxuchilensis Trel. Q. impressa Trel. Q. seleri Trel. $Q$. crassivenosa Trel. $Q$. spathulistipula Trel. $Q$. verrugosirana Trel.

Trees 8-15 m tall; twigs 1-2 (4) mm in diam., brown, glabrous or glabrescent with some fasciculate sessile trichomes, with few, small and pale lenticels, sometimes inconspicuous; buds ovoid, ellipsoid to conical, 1.8-3.6 mm long, scales broadly ovate, amber, margin fimbriate; stipules deciduous. Mature leaves with petioles 3-12.5 (15) $\times 0.4-0.7$ (1.5) mm, glabrous to glabrescent; blades coriaceous, oblanceolate, obovate, elliptic or oblong, 4-12.5 × 1.5-4.5 cm, 2-2.5 times longer than wide; base obtuse, subcordate, truncate or slightly oblique; margin thickened, sometimes broadly crispate, with 2-5 (6) short aristate teeth located in the distal half or distal third of the blade, sometimes only aristate (without teeth); apex acute to obtuse, tip with a short arista; secondary veins (5) 8-13 on each side of the midvein, ascending, straight or moderately curved, branching and anastomosing toward the margin, the upper continuing into the tooth and the arista; adaxial blade surface slightly rugose, slightly shiny or sometimes dull, glabrous, secondary veins and veinlets impressed, midvein slightly prominent and pale; abaxial blade surface glabrescent or densely pubescent with fasciculate sessile trichomes, the rays crispate, with or more usually without glandular trichomes, midvein, secondary veins and veinlets pale and prominent; epidermis bullate. Fruits annual, 1-2 sessile or on a glabrous or glabrescent 
peduncle 2-3 (7) mm long; cupules hemispheric or slightly obconical, 7-12.5 (13) mm diam. $\times$ 3-7 (8) mm tall, margin erect, scales smooth, deltoid, canescent, margin brown-reddish; acorns ovoid, glabrous or rarely sparingly canescent toward the apex, 9-12 mm long $\times 8-11 \mathrm{~mm}$ diam., included $1 / 3$ of their total length in the cupule (Figure $2 \mathrm{~F}$ ).

Distribution and ecology. Widely distributed in Mexico, in the Sierra Madre Occidental, Transmexican Volcanic Belt, Sierra Madre Oriental and the Sierra Madre del Sur; in the states of Chiapas, Ciudad de Mexico, Colima, Durango, Guanajuato, Guerrero, Hidalgo, Jalisco, Mexico, Michoacan, Morelos, Nayarit, Oaxaca, Puebla, Queretaro, San Luis Potosi, Sinaloa, Sonora and Veracruz; reaching Guatemala. In Hidalgo state, Q. castanea can be found in pine-oak forests, oak forests, juniper forests, cloud forest and border of arid tropical scrub. Associated with Cupressus sp., Juniperus flaccida, Bouteloua gracilis, Prunus sp., Quercus affinis, Q. crassifolia, Q. laeta, $Q$. mexicana and $Q$. meavei; in red, rocky or shallow soils, in ravines or open areas; at elevations from 1,600 to 2,490 m. Flowering in March and April; fruits mature from September to January.

Taxonomic comments. Quercus castanea has often been confused with Quercus eduardi and $Q$.crassipes; however it can be distinguished by its abaxial blade surface with fasciculate sessile trichomes with crispate rays and bullate epidermis, adaxial blade surface rugose, blade margin dentate, and cupules with erect margin. $Q$. eduardi differs in its flat epidermis and fasciculate sessile contorted trichomes uniformly scattered on the abaxial blade surface, as well as a flat adaxial blade surface. On the other hand, $Q$. crassipes has fasciculate stipitate trichomes on the abaxial blade surface, the blade margin is entire, and the cupules present an involute rim.

It is controversial to consider $Q$.tristis as synonym of $Q$. castanea (Muller 1942, Valencia-A. 2004, Valencia \& Flores-Franco 2006, Villaseñor 2016). Specimens collected in Chiapas and Guatemala, show constant differences from those collected in the central of Mexico, such as: completely glabrous abaxial blade surface, with prominents veins and veinlets, and the shape of the leaves is oblong to oblanceolate. These characters are how we could differentiate these as two species, however additional studies, mainly in field and with molecular characters should be done to make the best decision.

Quercus corrugata Hook., Icones Plantarum 5: pl. 403-404. 1842. Type: Guatemala. Cerro del Tambor, Skinner 5; 1840 (holotype: K!).

= Quercus corrugata var. granulifera Trel. Q. corrugata var. ipalensis Trel. Q. corrugata var. microcarpa Wenz. Q. cyclobalanoides Trel. Q. pilgeriana Seem. Q. reevesii Trel.

Trees $15-30 \mathrm{~m}$ tall; twigs $1.2-3.5 \mathrm{~mm}$ in diam., glabrous to slightly puberulent, brown, lenticels whitish to pale, raised and conspicuous; buds globose or ovoid, 2.4-4 mm long, scales broadly ovate, glabrous, amber, margin lacerate and whitish; stipules linear, strigose, ca. 7.3 $\mathrm{mm}$ long, deciduous or persisting in the apical buds. Mature leaves with petioles (12) 16-31 $\times$ 0.5-1.2 mm, glabrous, thickened and dark basally; blades subcoriaceus, elliptic, elliptic-lanceolate, sometimes oblanceolate or oblong, 7-17.5 × 2.8-4.5 (6.5) cm, 2.2-3.5 times longer than wider; base rounded, decurrent or cuneate, sometimes asymmetric; margin slightly revolute or not, crispate, with 8-16 mucronate and ascending teeth; apex acute; secundary veins (9) 11-18 on each side of the midvein, parallel, ascending and straight, passing into the teeth and continuing towards the mucro; adaxial blade surface glabrous, shiny, primary, secondary veins and veinlets slightly prominent; abaxial blade surface glabrous or glabrate, with a few appressed acute unicellular trichomes on the midvein and secondary veins, with or without some tiny stellate trichomes at the base of the blade, primary and secondary veins prominent, veinlets barely prominent, epidermis papillose. Fruits annual, solitary, sessile or on a short peduncle ca. $5.6 \mathrm{~mm}$ long; cupules hemispheric to patelliform, 15-22 mm diam. $\times 4-10 \mathrm{~mm}$ tall, margin erect, scales thickened basally and slightly tomentose; acorns ovoid, glabrous, 20-23 mm long $\times 15-20 \mathrm{~mm}$ diam., included $1 / 3$ of their total length in the cupule (Figures $2 \mathrm{G}$ and $7 \mathrm{C}$ ).

Distribution and ecology. Southern Sierra Madre Oriental, Sierra Madre del Sur and mountains of Chiapas; in the states of Chiapas, Guerrero, Hidalgo, Oaxaca, Puebla and Veracruz; reaching Costa Rica. In Hidalgo state it is restricted to the eastern and wettest region, in the cloud forest. Associated with Clethra sp., Fagus grandifolia subsp. mexicana, Magnolia schiedeana, Pinus patula, Quercus delgadoana and Q. meavei; at elevations from 1,750 to 1,928 $\mathrm{m}$. Flowering time for Hidalgo unknown; fruits mature from August to October. 
Taxonomic comments. Quercus corrugata can be confused with $Q$. lancifolia, but it is readily distinguished by its glabrous or glabrate leaves, elliptic, elliptic-lanceolate, oblanceolate or oblong, subcoriaceous blades; the blade margin is toothed above the base, the blades have a greater number of secondary veins (11-18 on each side of midvein). Additionally it presents larger fruits, and cupules with basally thickened scales. Shorter petioles (4-10 mm long), and cuneate bases can be present in young plants or in sprouts.

Quercus crassifolia Bonpl. Pl. Aequinoct. 2: (43) 49, pl. 91. 1801. Type: Mexico. Guerrero, Chilpancingo, Bonpland s.n. (holotype: P).

$=$ Quercus stipularis Bonpl. Q. brachystachys Benth. Q. spinulosa M. Martens et Galeotti. Q. splendens var. pallidior A. DC. Q. felipensis Trel. Q. moreliana Trel. Q. errans Trel. Q. chicamolensis Trel. Q. orbiculata Trel.

Trees 4-15 (23) m tall; twigs 2.3-4.5 (6) $\mathrm{mm}$ in diam., furrowed, densely tomentose, indument yellowish to amber, with fasciculate estipitate trichomes, lenticels not visible; buds ovoid to long-ovoid, (3)4-10 mm long, scales ovate, slightly sericeus, margin fimbriate, the superior scales golden and pilose; stipules deciduous or persisting in the apical buds, oblanceolate, strigose, 8.7-13.5 mm long. Mature leaves with petioles (3) 7-30 (35) × 1.9-3.5 $\mathrm{mm}$, tomentose, slightly yelowish, with fasciculate sessile trichomes; blades thick and coriaceous, obovate, (7) 10-17.5 $\times 4.1-11.5 \mathrm{~cm}, 1.4-1.8$ times longer than wider; base cordate, subcordate, truncate, rounded or slightly decurrent; margin thick, slightly revolute, with 3-8 aristate teeth on each side of the blade located on the distal middle or distal fourth part of the blades, sometimes only aristate (without teeth); apex obtuse to rounded; secondary veins (6) 7-10 on each side of the midvein, ascending, moderately curved, sometimes almost straight, branching or not near the margin, the upper continuing directly into the teeth and the arista; adaxial blade surface prominently rugose, somewhat shiny or dull, green-gray or dark-green, glabrous or glabrate with some fasciculate stipitate trichomes along the midvein, secondary veins and veinlets impressed; abaxial blade surface with yellowish indument, densely tomentose to woolly, with fasciculate stipitate trichomes, the rays crispate, intertwined and hiding the amber glandular trichomes and the bullate epidermis. Fruits biennial, 1-4 on a yellowish to gray, glabrescent to tomentose peduncle, 10.4-16.9 (20) mm long; cupules hemispheric, 9.815.6 diam $\times 6.4-10 \mathrm{~mm}$ tall, margin erect, scales smooth, slightly canescent; acorns ovoid, glabrous 10.5-13.5 mm long $\times 6.6-10.7 \mathrm{~mm}$ diam., included $1 / 4-1 / 3$ of their total length in the cupule (Figures $2 \mathrm{H}$ and $7 \mathrm{D}$ ).

Distribution and ecology. Widely distributed in Mexico, in the Sierra Madre Occidental, Sierra Madre Oriental, Transmexican Volcanic Belt, Sierra Madre del Sur, mountains of Chiapas and Central America; in the states of Chihuahua, Durango, Guanajuato, Guerrero, Hidalgo, Jalisco, Mexico, Michoacán, Oaxaca, Puebla, Querétaro, San Luis Potosí, Tlaxcala, Veracruz and Zacatecas; reaching Guatemala. In Hidalgo state in deep soils, in arid tropical scrub, oak forests, pine-oak forests, and cloud forest. Associated with Liquidambar styraciflua, Dalbergia sp., Quercus affinis, Q. laurina, Q. crassipes, Q. mexicana and Q. rugosa; at elevations from 1,533 to 2,850 m. Flowering in April and May; fruits mature in October.

Taxonomic comments. Quercus crassifolia can be easily distinguished by its blades, which are coriaceous, rugose adaxially, abaxial blade surface with yellowish and densely tomentose to woolly indument. $Q$. crassifolia hybridizes with $Q$. crassipes Bonpl. (Tovar-Sánchez \& Oyama 2004) and the hybrids are known as $Q . \times$ dysophylla Benth.

Quercus crassipes Bonpl. Pl. Aequinoct 2: 37. pl. 83. 1809. Type: Mexico. Guanajuato. Santa Rosa, Bonpland s.n. (isolectotype: P!).

$=$ Quercus colimae f. zaucillo Trel. $Q$. colimae Trel. $Q$. confertifolia Bonpl. $Q$. mexicana var. confertifolia (Bonpl.) Wenzig. Q. mexicana f. confertifolia (Bonpl.) Trel. Q. crassipes var. angustifolia Bonpl. Q. mexicana f. angustifolia (Bonpl.) Trel. Q. cuajimalpana Trel. Q. imbricariaefolia Trel. Q. malifolia Trel. Q. mexicana var. glabrata Liebm. ex Seem. Q. castanea var. glabrata (Liebm. ex Seem.) A. DC. Q. obovalifolia E. Fourn. ex Trel.

Trees (8) 10-20 m tall; twigs 1-2 (4) mm diam., tomentose to glabrescent, brown, yellow 
or whitish, stellate trichomes intermixed with fasciculate trichomes, lenticels inconspicuous; buds ovoid 1.5-3.7 (4.5) mm long, scales broadly ovate, brown-reddish, margin ciliate; stipules deciduous or persistent on the apical buds, linear-lanceolate, slightly pilose, 6-8 $\mathrm{mm}$ long. Mature leaves with petioles 2-7 (10) $\times 0.5-1 \mathrm{~mm}$, tomentose to glabrescent, with stellate trichomes intermixed with fasciculate trichomes; blades coriaceous, elliptic, oblong, lanceolate or oblanceolate, 4-9 (11) × 1-3 (3.5) cm, (3) 3.4-4 times longer than wide; base rounded to subcordate; margin entire and revolute; apex rounded or subacute, aristate; secondary veins 10-19 on each side of the midvein, straight or moderately curved towards the margin, often arising at almost a right angle from the midvein, branching and anastomosing near the margin; adaxial blade surface rugose, slightly shiny, dark green or grayish green, glabrous or with scarce stellate trichomes towards the base and margin of the blade and along the midvein, primary and secondary veins impressed; abaxial blade surface glabrescent or densely pubescent with fasciculate stipitate trichomes, the rays crispate, if densely pubescent the rays intertwined and hide the amber glandular trichomes, epidermis bullate. Fruits biennial, 1-2 on a peduncle 5-12 mm long; cupules hemispheric $12-20 \mathrm{~mm}$ diam. $\times 8-12 \mathrm{~mm}$ tall, margin frequently involute, scales thickened basally and slightly tomentose; acorns ovoid, 10-16 mm long $\times 10-12 \mathrm{~mm}$ diam, glabrous, included $1 / 3$ of their total length in the cupule (Figures $2 \mathrm{I}$ and 7E).

Distribution and ecology. Endemic to Mexico, in the Transmexican Volcanic Belt and the southern part of the Sierra Madre Oriental; in the states of Colima, Mexico City, Guanajuato, Hidalgo, Jalisco, Mexico, Michoacan, Morelos, Puebla, Queretaro and Tlaxcala. In Hidalgo state it occurs in oak and pine-oak forests. Associated with Quercus crassifolia and $Q . \times$ dysophylla; at elevations from 2,190 to 2,678 m. Flowering from March to May; fruits mature from September to November.

Taxonomic comments. Quercus crassipes can be confused with $Q$. mexicana and $Q$. castanea; but it can be distinguished from Q. mexicana by its cupules with an involute rim, the secondary veins arising at an angle almost erect with respect to the midvein and the fasciculate stipitate trichomes on the abaxial blade surface; Q. mexicana has a cupule with an erect margin, secondary veins arising at an angle of less than $90^{\circ}$, and fasciculate sessile contorted trichomes on the abaxial blade surface. On the other hand, $Q$. castanea has annual fruits, fasciculate sessile trichomes on the abaxial surface, and a blade margin with usually 2-3 teeth located toward the apex, while $Q$. crassipes has biennial fruits, fasciculate stipitate trichomes on the abaxial blade surface, and the blade margin is entire and slightly revolute.

Quercus delgadoana S. Valencia, Nixon et L.M. Kelly. Novon. 21 (2): 274-277. 2011. Type: Mexico. Hidalgo. Municipio Tlanchinol: Km 165 de la carr. Tlanchinol-Tampico, ca. $5 \mathrm{~km}$ al sur de la desviación de Lontla, $21^{\circ} 00^{\prime}$ N y $98^{\circ} 39^{\prime}$ W, 1540. 23 Oct. 2008, S. Valencia A., A. Coombes y K. Vega 3748 (holotype: FCME!; isotypes: HUAP!, MEXU!).

Trees 20-25 (30) m tall; twigs 1-2 (3) mm in diam., glabrous, lenticels inconspicuous; buds conical, glabrous, (0.6) 1-6 (6.5) mm long, scales ovate or long ovate, glabrous, margin ciliate; stipules deciduous. Mature leaves with petioles 2-10 × 1-2 mm, glabrous, dark basally; blades coriaceous or thick coriaceous, narrowly oblong, elliptic or lanceolate, (3.1) 4-12.5 (15.4) $\times$ (0.9-) 3.8-5.3 cm, 2.6-4.5 (6) times longer than wider, base cuneate or rounded; margin entire, slightly thick and revolute; apex acute to acuminate, tip aristate; secondary veins 9-20 on each side of the midvein, ascending, straight or moderately curved towards the margin, branching and anastomosing in the distal third, occasional evanescent intermediates are present; adaxial blade surface green-grayish or glaucous, somewhat shiny or dull, glabrous, midvein and secondary veins impressed; abaxial blade surface slightly paler than adaxial surface, glabrous or with tufts of fasciculate stipitate trichomes in the axils of the secondary veins, epidermis slightly papillose, midvein and secondary veins prominent, veinlets smooth or barely prominent. Fruits biennial, 1-2 on a glabrous peduncle 1-1.5 mm long; cupules obconic to slightly turbinate, 6-15 mm diam. $\times 3-8 \mathrm{~mm}$ tall, margin erect, scales smooth, ovate and canescent; acorns ovoid, glabrous, $18.3-22.9 \mathrm{~mm}$ long $\times 10.8-13 \mathrm{~mm}$ diam., included $1 / 2$ to $1 / 3$ of their total length in the cupule (Figure 3A). 
Distribution and ecology. Endemic to Mexico, in the Sierra Madre Oriental; in the states of Hidalgo, Puebla and Veracruz. In Hidalgo state it occurs in moist oak forests and cloud forests. Associated with Fagus grandifolia subsp. mexicana, Quercus affinis, Q. corrugata, Q. meavei; at elevations from 1,400 to 1,940 m. Flowering time for Hidalgo state is unknown; fruits mature in September and October.

Taxonomic comments. Quercus delgadoana is distinguished from Quercus sapotifolia by its biennial fruits, the secondary veins are impressed adaxially, and its leaves are slightly glaucous to green-gray with an acute to acuminate apex. It can also be confused with $Q$. trinitatis however $Q$. delgadoana can be distinguished by its narrowly oblong, elliptic or lanceolate and coriaceous blades, and its leaves with 9-20 secondary veins, which are impressed adaxially, while $Q$. trinitatis has lanceolate blades, and fewer secondary veins, rarely impressed.

Quercus depressa Bonpl. Plant. Aequinoct., 2:50, pl. 92. 1809. Type: Mexico. Hidalgo. El Jacal, Morán, Bonpland 4145 (holotype: B!).

= Quercus subavenia Trel.

Shrubs 30-50 (120) cm tall, clonal, rhizomatous growth; twigs 0.9-1.5 mm in diam., furrowed, glabrescent with stellate trichomes, lenticels inconspicuous; buds ovoid, 1.7-3 mm long, brown, scales ovate, near glabrous, margin ciliate; stipules deciduous. Mature leaves with petioles 2-5 $\times 0.5-2 \mathrm{~mm}$, glabrescent with some stellate trichomes; blades coriaceous, elliptic to elliptic-oblong, 2-4 × 1-2 cm, 1.7-2.2 times longer than wider; base cuneate or slightly rounded; margin slightly revolute, entire or with 1-2 short aristate teeth towards the apex; apex acute to obtuse; secondary veins 5-8 on each side of the midvein, ascending and moderately curved; adaxial blade surface shiny, green-yellowish, generally glabrous or with scarse and scattered stellate trichomes towards the base, midvein, secondary veins and veinlets slightly prominent or flat; abaxial blade surface glabrous or with some stellate trichomes near the base of the blade, epidermis slightly papillose or flat, midvein, secondary veins and veinlets slightly prominent and pale. Fruits biennial, 1-2 subsessiles; cupules hemispheric to slightly turbinate, margin erect, 8-11 mm diam. $\times 5-7 \mathrm{~mm}$ tall, scales smooth, triangular or ovate-triangular, scarcely pubescent; acorns globose-ovoid, 9-13 mm long $\times 7-10 \mathrm{~mm}$ diam., included 1/2 to $1 / 4$ of their total length in the cupule (Figure 3B).

Distribution and ecology. Endemic to Mexico, in the Sierra Madre Oriental; in the states of Hidalgo, Oaxaca, Puebla and Veracruz. It is a very rare species in Hidalgo, found in oak forest and oak-pine forests. Associated with $Q$. repanda, Q. laurina, $Q$. crassifolia and Pinus sp.; at elavations from 2,700 to $3,140 \mathrm{~m}$. Flowering time for Hidalgo state is unknown; fruits mature from August to November.

Taxonomic comments. In Hidalgo state, this species is restricted to the highlands and the top of the Cerro de Las Navajas. Quercus depressa can be confused with Q. affinis and Q. laurina, however $Q$. depressa is a shrub.

Quercus deserticola Trel. Mem. Natl. Acad. Sci.20: 79, pl. 113. 1924. Type: Mexico. Desierto, Querétaro, Uhde 309 (holotype: B).

= Quercus alveolata Trel. Q. texcocana Trel.

Trees 6-9 m tall; twigs 1.5-2.7 (3.5) $\mathrm{mm}$ in diam., densely tomentose, indument yelowish to gray, fasciculate shortly stipitate trichomes hide the whitish fasciculate sessile trichomes, lenticels not visible; buds ovoid to globose-ovoid, 2.4-3.5 mm long, scales broadly ovate, brown, slightly strigulose-canescent, margin ciliate; stipules linear, sericeous-canescent, 4-9 mm long. Mature leaves with petioles $3-8(12) \times 0.8-1.5 \mathrm{~mm}$, yellowish to gray tomentose, with the same aspect and trichomes as the twigs; blade coriaceous, oblanceolate, elliptic or oblong (3) 4-8.5 (10) $\times 1.5-3 \mathrm{~cm}$, 2-2.7 times longer than wider; base subcordate, rounded or obtuse, margin thick, conspicuously revolute, entire, sinuate or with 1-3 (5) mucron, apex obtuse to rounded, tip mucronate, secondary veins 6-9 (12) on each side of the midvein, ascending, straight or slightly curved, branching and anastomosing near the margin, the distal veins extend to the teeth into the mucros; adaxial blade 
surface rugose, somewhat gray-yellowish, dull, pilose with fasciculate stipitate trichomes especially near the midvein and secondary veins, the midvein, secondary veins and veinlets impressed; abaxial blade surface lanuginous, with fasciculate stipitate trichomes, the rays intertwined, epidermis bullate. Fruits annual, 1-2 sessile or on a yellowish tomentose peduncle 1.0-2.5 cm long; cupules hemispheric to deeply hemispheric, $15-20 \mathrm{~mm}$ diam. $\times 10-16 \mathrm{~mm}$ tall, margin erect, scales sligthly thickened basally and canescent; acorns ovoid, $12-18 \mathrm{~mm}$ long $\times 11-15 \mathrm{~mm}$ diam., included $1 / 3$ to $1 / 2$ of their total length in the cupule (Figures $3 \mathrm{C}$ and $7 \mathrm{~F}$ ).

Distribution and ecology. Endemic to Mexico, in the Transmexican Volcanic Belt, the southern part of the Sierra Madre Occidental and the Sierra Madre Oriental; in the states of Ciudad de Mexico, Guanajuato, Hidalgo, Jalisco, Mexico, Michoacan, Oaxaca, Puebla and Queretaro. In Hidalgo in arid tropical scrub and in oak forests. Associated with Eysenhardtia polystachya, Agave sp., Opuntia sp. and Fraxinus greggii, on basalt soils; at elevations from 2,000 to 2,700 m. Flowering in April; fruits mature in August and September.

Taxonomic comments. Quercus deserticola, can be confused with $Q$. laeta but can be distinguished by its yellow-tomentose twigs; revolute blade margin, the adaxial and abaxial blade surfaces are tomentose with fasciculate stipitate trichomes; $Q$. laeta has glabrescent twigs and a scarcely revolute or only slightly thickened blade margin; the adaxial blade surface is glabrous or glabrescent; the abaxial blade surface has fasciculate sessile trichomes loosely located on the papillose epidermis.

Quercus × dysophylla Benth., Pl. Hartweg. 55. 1840. Type: Mexico. Huasca, Hartweg 421 (holotype: K).

$=$ Quercus hahnii Trel. Q. esperanzae Trel. Q. fournieri Trel. Q. sagata E. F. Warb.

Trees 5-15 m tall; twigs 1-3 (4) mm in diam., furrowed, glabrescent, tomentose or densely tomentose, with reddish brown, fasciculate stipitate trichomes, lenticels not visible; buds ovoid, 2$4.5 \mathrm{~mm}$ long, scales broadly ovate, pilose, brown, margin ciliate; stipules deciduous, sometimes the apical are present and linear to long oblanceolate, $4-9 \mathrm{~mm}$ long, pubescent. Mature leaves with petioles (2) 4-7 (15) $\times 1-2.5 \mathrm{~mm}$, densely tomentose with fasciculate sessile trichomes; blades coriaceous, ovate, lancolate, elliptic, elliptic-oblong or obovate, (3) 5-13 (16) $\times$ (1) 2-5 (6.5) $\mathrm{cm}, 2.5-3.5$ times longer than wider, base rounded to cordate, margin revolute, entire or undulate, sometimes with 1-2 aristate teeth or with only aristae towards the apex; apex obtuse to acute, tip aristate, secondary veins (7) 9-16 on each side of the midvein, ascending, straight or moderately curved, branching and anastomosing in the distal third or near the margin; adaxial blade surface pale green to olive-green, rugose, slightly shiny, glabrous or with fasciculate sessile trichomes along the veins and veinlets, midvein, secondary veins and veinlets impressed; abaxial blade surface tomentose to lanuginous, yellowish, with fasciculate stipitate trichomes, the rays intertwined and hiding the amber glandular trichomes and the bullate epidermis. Fruits biennial, 1-2 sessile or on a pubescent peduncle 1-5 mm long; cupules turbinate 10-15 mm diam. $\times 8-12 \mathrm{~mm}$ tall, margin erect or incurved; scales smooth, canescent; acorns ovoid, glabrous or sparsely puberulent, $12-19 \mathrm{~mm}$ long $\times 10-14 \mathrm{~mm}$ diam., included for about $1 / 3$ to $1 / 2$ of their total length in the cupule (Figures 3D and 7G).

Distribution and ecology. Endemic to Mexico and Guatemala, in the Sierra Madre Oriental and the eastern part of the Transmexican Volcanic Belt; in the states of Chiapas, Guanajuato, Hidalgo, Ciudad de Mexico, Mexico, Michoacan, Oaxaca, Puebla, Queretaro, San Luis Potosi, Tlaxcala and Veracruz. In Hidalgo state it is scarce in pine-oak forests and oak forests. Associated with Quercus castanea, Q. crassifolia, Q. crassipes, Q. laeta, Q. rugosa, Pinus sp., Prunus sp., Agave sp., Arbutus sp. and Buddleja sp.; at elevations from 2,220 to 2,714 m. Flowering in April; fruits mature from August to October.

Taxonomic comments. Quercus dysophylla was described by Bentham (1840), but later studies (Tovar-Sánchez \& Oyama 2004) showed that it is the result of hybridization between Q.crassifolia and $Q$. crassipes. Due to its hybrid condition, the morphology varies between individuals similar to $Q$. crassifolia to those similar to $Q$. crassipes. 
Quercus eduardi Trel., Contr. U. S. Natl. Herb. 23:189. 1922. Type: Mexico. Durango, Palmer 956; April-November 1896 (holotype: B).

= Quercus oligodonta Seemen ex Loes. not Q. oligodonta Saporta. Q. eduardi f. cespitifera Trel. Q. nitidissima Trel.

Trees 5-9 (18) $\mathrm{m}$ tall, or shrubs 2-6 m tall; twigs 1-2.6 mm in diam., green to brown, glabrescent or slightly pubescent with fasciculate sessile trichomes, lenticels inconspicuous; buds ovoid, acute, 1.5-4.3 mm long, brown, scales broadly ovate, shiny, glabrous, margin ciliate; stipules deciduous. Mature leaves with petioles 2-5 (8) $\times 0.8-1.5 \mathrm{~mm}$, reddish to greenish, finely tomentose to glabrescent; blades coriaceous, oblong-elliptic, ovate-lanceolate, oblanceolate or obovate, 2-5.5 (7) $\times(0.6) 1-2(4.6) \mathrm{cm}, 1.5-3.5$ times longer than wider; base cordate, subcordate or rounded, sometimes truncate; margin thick, flat or sligthly revolute, with 1-6 aristate teeth on each side of the blade, located in the distal half of the blade, rarely entire; apex acute or subacute, sometimes obtuse or rounded; secondary veins 5-8 on each side of the midvein, ascending, straight or moderately curved, branching and anastomosing towards the margin; adaxial blade surface shiny, dark green or grayish green, with stellate trichomes near the base, secondary veins and veinlets prominent or flat, slightly yellowish or green; abaxial blade surface with fasciculate sessile contorted trichomes, uniformly scattered on the surface, epidermis flat. Fruits annual, 1-3 subsessile or on peduncle ca. $10 \mathrm{~mm}$ long; cupules hemispheric to infundibuliform, 7-10 mm diam. $\times$ 5-7 mm tall, margin erect, scales smooth, apex rounded, slightly canescent; acorns ovoid 6-12 mm long $\times$ 6.9-7.3 mm diam., with scarce trichomes towards the apex; included ca. $1 / 2$ of their total length in the cupule (Figure 3E).

Distribution and ecology. Endemic to Mexico, in the Sierra Madre Occidental, Sierra Madre Oriental and Mexican Plateau; in the states of Aguascalientes, Durango, Guanajuato, Hidalgo, Jalisco, Nayarit, Nuevo Leon, Queretaro, San Luis Potosi, Tamaulipas, Veracruz and Zacatecas. In Hidalgo state it occurs in pine-oak forests, oak forests and arid tropical scrub. Associated with Juniperus sp., Pinus teocote, Quercus crassifolia, Q. deserticola, Q. xylina, $Q$. mexicana and Q. repanda; on limestone soils; at elevations of 1,700 to 2,550 m. Flowering time unknown for Hidalgo state; fruits mature from August to November.

Taxonomic comments. Quercus eduardi can be confused with Quercus mexicana because both have fasciculate stipitate contorted trichomes; however $Q$. eduardi can be distinguished by its oblong-elipitic, ovate-lanceolate, oblanceolate or ovate leaves; aristate-toothed blade margin and flat epidermis; while in Q. mexicana the leaves are elliptic, lanceolate to oblong, with an entire and slightly revolute margin, and bullate and papillose epidermis. It can also be confused with $Q$. tinkhamii, but that is a white oak and lacks aristate teeth. Additionally $Q$. tinkhamii has stellate trichomes on both surfaces of the blade.

Quercus frutex Trel. Mem. Natl. Acad. Sci. 20:82. pl. 120. 1924. Type: Mexico. Mexico; Valley of Mexico, Guautepec, Bourgeau 68 (holotype: P).

Shrubs 0.3-2 m tall; twigs 1-2.2 mm in diam., densely tomentose, yellowish when young, blackish with age, with fasciculate shortly stipitate trichomes, lenticels not visible; buds globose-ovoid, (0.5) $0.8-2 \mathrm{~mm}$ long, scales broadly ovate, brown to amber, glabrescent, margin ciliate; stipules deciduous or not before the leaves reach maturity, linear or filiform 4-5.6 mm long, sparsely pubescent. Mature leaves with petioles $1-7 \times(0.2) 0.5-1(-2) \mathrm{mm}$, tomentose to glabrescent, indument yellowish to gray, with fasciculate shortly stipitate trichomes; blades subcoriaceous to thick, elliptic, elliptic-oblong or oblong, 1.2-4.8 × 0.7-1.5 (3.8) cm, 2-3.3 (4) times longer tan wider; base rounded to subcordate, sometimes cuneate; margin slightly thick, revolute, entire, sometimes crenate; apex obtuse to rounded, tip shortly mucronate; secondary veins 5-8 (10) on each side of the midvein, ascending, straight to moderately curved, branching and anastomosing near the margin; adaxial blade surface sligthly gray-green and slightly rugose, pubescent with fasciculate shortly stipitate trichomes, scattered on the surface; midvein and secondary veins impressed; abaxial blade surface pale green to whitish, tomentose, with fasciculate stipitate trichomes, the rays curved or crispate and intertwined hiding the epidermis which is bullate and papillose; scarce appressed acute unicellular trichomes along the midvein. 
Fruits annual, 1-2 sessile or on a peduncle ca. $2 \mathrm{~cm}$ long; cupules hemispheric, (8) 10-15 mm diam. $\times 5-9 \mathrm{~mm}$ tall, margin erect, scales appressed, the basal scales slightly thickened towards the base; acorns ovoid to broadly ovoid, 9-14 $\mathrm{mm}$ long $\times 7-12 \mathrm{~mm}$ diam., included for about 1/3 to $1 / 2$ of their total length in the cupule (Figure $3 \mathrm{~F}$ and $7 \mathrm{H}$ ).

Distribution and ecology. Endemic to Mexico, in the Transmexican Volcanic Belt and southern part of the Sierra Madre Oriental; in the states of Ciudad de Mexico, Hidalgo, Mexico, Michoacan, Oaxaca, Puebla, Queretaro, Tlaxcala and Veracruz. In Hidalgo state it occurs in oak forests, pine forests, Abies forests, Cupressus forests and arid tropical scrub. Associated with Abies religiosa, Quercus mexicana and Cupressus sp.; at elevations of 2,170 to 3,000 m. Flowering in April; fruits mature from July to September.

Taxonomic comments. Quercus frutex can be confused with the shrubby species Quercus microphylla; however $Q$. frutex can be distinguished by its slightly thick blades with revolute margins and stipitate trichomes on the abaxial blade surface; while $Q$. microphylla has subchartaceous leaves with a flat or slightly revolute margin, and fasciculate sessile trichomes on the abaxial blade surface.

Quercus furfuracea Liebm. Overs. Kongel. Danske Vidensk. Selsk. Forh. Medlemmers Arbeider. 1854: 189. 1854. Type: Mexico. Puebla, Chinautla, Liebmann 3438 (holotype: C!).

Trees 8-15 m tall; twigs 1.6-2.4 (3) $\mathrm{mm}$ in diam., slightly furrowed, brown, floccose with yellowish stellate trichomes, lenticels incospicuous; buds ovoid, 2.5-4.1 mm long, scales ovate to broadly ovate, reddish brown to amber, glabrous or with acicular appressed trichomes, margin ciliate; stipules deciduous. Mature leaves with petioles 0.8-22 $\times 0.7-1 \mathrm{~mm}$, yellowish floccose to glabrescent; blade coriaceous, elliptic, ovate or lanceolate, (4) $5-13.5 \times(1.5) 2.5-5.5 \mathrm{~cm}, 1.8$ 2.8 times longer tan wider; base rounded, cuneate or truncate; margin with (3) 5-8 aristate short teeth located in the distal 2/3 - 3/4 of the blade, slightly crispate or flat; apex acute to acuminate, tip aristate; secondary veins 6-9 on each side of de midvein, ascending, straight to moderately curved, the superior veins continuing directly into the tooth and towards the arista if present, otherwise branching and anastomosing near the margin; adaxial blade surface glabrous or glabrescent with stellate multiradiated trichomes specialy towards the base of midvein, slightly shiny, secondary veins and veinlets flat or barely prominent; abaxial blade surface with scattered stellate multiradiated trichomes, crowded towards the midvein, with tufts of fasciculed stipitate trichomes in the axils of the secondary veins and near these, epidermis papillose or smooth. Fruits annual, 1-2 subsessile or on a peduncle 2-5 mm long; cupules hemispheric to slightly turbinate, $11-13 \mathrm{~mm}$ diam. $\times 7-10 \mathrm{~mm}$ tall, margin erect, scales smooth and appressed, apex acute to obtuse, base slightly pubescent; acorns ovoid, glabrous 12.6-13.5 mm long $\times$ 10.6-12 $\mathrm{mm}$ diam., included $1 / 2$ to $1 / 3$ of their total length in the cupule (Figure $3 \mathrm{G}$ ).

Distribution and ecology. Endemic to Mexico, in the Sierra Madre Oriental; in the states of Hidalgo, Puebla and San Luis Potosi. It is a scarce species in Hidalgo state, found in oak forests, pine-oak forests and cloud forests. Associated with Quercus affinis, Q. candicans, Q. germana, Q. mexicana, $Q$. polymorpha and Pinus patula; in limestone soils; at elevations from 710 to $1,975 \mathrm{~m}$. Flowering time for Hidalgo state is unknown; fruits mature in September.

Taxonomic comments. Quercus furfuracea resembles $Q$. sartorii in leaf characters, especially the form and dimension of blades which can be similar; however $Q$. furfuracea can be distinguished by its floccose twigs, petiole and veins, while in $Q$. sartorii the twigs, petiole and veins are glabrous or glabrescent.

Quercus germana Schltdl. et Cham. Linnaea 5: 78. 1830. Type: Mexico, (Veracruz), Jalapa, Schiede 21 (holotype: HAL).

= Quercus galeottii M. Martens. Q. germana var. echinata Trel. Q. germana subsp. subsquarrosa A. Camus.

Trees 8-16 (20) $\mathrm{m}$ tall; twigs 2-3.5 mm in diam., glabrous or with scarce stellate trichomes, 
lenticels pale to gray, prominent; buds ovoid to globose, 1-4.5 $\mathrm{mm}$ long, scales ovate, margin ciliate, pilose; stipules oblanceolate, 3.3-10 mm long, pilose, scarious or rigid, generally deciduous, sometimes persistent on apical buds. Mature leaves with petioles 3-6 $61-3 \mathrm{~mm}$, glabrous or with scarce stellate trichomes; blades coriaceous, elliptic, obovate or oblanceolate, 13-19 (26) $\times$ (3.5) 6-8.2 (12.5) cm, 1.9-2.6 times longer than wider; base rounded to subcordate, occasionally cordate; margin slightly revolute, entire, undulate or with 1-7 short mucronate teeth or lobes towards the distal half of the blade; apex obtuse, acute or acuminate, tip mucronate; secondary veins 10-17 on each side of the midvein, ascending, straight or moderately curved, continuing towards the teeth if present, otherwise branching and anastomosing near the margin; adaxial blade surface glabrous, shiny or scarcely shiny, midvein and secondary veins slightly impressed, veinlets slightly prominent; abaxial blade surface glabrescent with scarce and scattered hyaline glandular trichomes, epidermis waxy-glaucous, papillose and barely bullate. Fruits annual, 1-3 on a glabrous peduncle, $12-45 \mathrm{~mm}$ long, frequently the peduncles are located towards the apex of the ultimate twigs, not in the leaf axils; cupules hemispheric or cupuliform, 28-35 mm diam. $\times 13-21 \mathrm{~mm}$ tall, margin erect, scales triangular, thickened basally, gray canescent; acorns ovoid to oblong-ovoid, glabrous or scarcely pubescent on the apex, 28-40 mm long $\times 18-28 \mathrm{~mm}$ diam., included $1 / 2$ to $1 / 4$ of their total length in the cupule (Figure $3 \mathrm{H}$ ).

Distribution and ecology. Endemic to Mexico, in the Sierra Madre Oriental; in the states of Hidalgo, Oaxaca, Puebla, San Luis Potosí, Tamaulipas and Veracruz. In Hidalgo state it occurs in cloud forests and moist oak forests. Associated with Quercus lancifolia, Q.pinnativenulosa, Platanus sp. and Alnus sp.; at elevations from 500 to 1,500 m. Flowering in April; fruits mature from September to November.

Taxonomic comments. This species can be identified readily. Its elliptic, obovate or oblanceolate, glabrate or almost glabrous leaves, with waxy-glaucous abaxial blade surface, large fruits on a peduncle which usually is at the apex of the ultimate twigs, clearly distinguishes it from the other species of Hidalgo state.

Quercus glabrescens Benth. Pl. Hartweg. 56: 348 1840. Type: Mexico; Hidalgo, Real del Monte, Hartweg 428 (isotype K!).

Tress 8-10 m tall; twigs 1-3 (4) $\mathrm{mm}$ in diam., glabrous or glabrescent with scarce and scattered fasciculate sessile trichomes, light brown to slightly yellowish, lenticels inconspicuous; buds ovoid to globose, 1-3 (4) mm long, glabrous or pubescent towards the base, scales ovate to broadly ovate, amber, margin ciliate; stipules linear, subulate or oblanceolate, (3.5) 5-6.5 (11) $\mathrm{mm}$ long, pilose-puberulent, strigose, deciduous, but a few are persistent on the apical buds. Mature leaves with petioles 1.5-8 (13) $\times 0.8-2 \mathrm{~mm}$, dark basally, glabrous, glabrescent or pubescent with fasciculate sessile trichomes and acicular unicellular trichomes, appressed; blades subcoriaceous, oblong, elliptic-oblong, oblanceolate or obovate, (2) 5-13.5 × 3-6 cm, 1.9-2.6 times longer than wider; base rounded, subcordate or cordate, sometimes cuneate; margin revolute, with 1-8 mucronate teeth located on the distal half or distal third of the blade, rarely slightly crispate; apex acute or obtuse, sometimes rounded, short mucronate tip; secondary veins (4) 6-11 on each side of the midvein, ascending, straight, continuing directly into the tooth if present, otherwise branching and anastomosing near the margin; adaxial blade surface dark green, scarcely shiny, rugose, glabrous, except the midvein which has scarce stellate trichomes, secondary veins and veinlets impressed; abaxial blade surface glabrous or glabrescent, with scattered fasciculate sessile trichomes, rays crispate, with some appressed acute unicellular trichomes along the midvein, epidermis slightly bullate and papillose, rarely flat. Fruits annual, 1-2 on a glabrous or glabrescent peduncle 14-32 mm long; cupules hemispheric, 14-17 mm diam. $\times$ 6-9 mm tall, margin erect, scales smooth, loosely appressed, ovate, apex slightly acuminate, glabrous and reddish, brown and canescent basally; acorns ovoid to oblong-ovoid, glabrous, 16-21 mm long $\times 13-19$ mm diam., included $1 / 3$ of their total length in the cupule (Figure 3I).

Distribution and ecology. Endemic to Mexico, in the Sierra Madre Oriental, the eastern part of the Transmexican Volcanic Belt and Sierra Norte of Oaxaca; in the states of Ciudad de Mexico, 
Hidalgo, Mexico, Oaxaca, Queretaro, Puebla, Tlaxcala and Veracruz. In Hidalgo it is found scarcely in the southeast of state, in oak forests, pine-oak forests and Abies forests; on river banks. Associated with Abies religiosa, Quercus affinis, Q. crassifolia and Q. rugosa; at elevations from 2,270 to $3,000 \mathrm{~m}$. Flowering time for Hidalgo state is unknown; fruits mature in September and October.

Taxonomic comments. Quercus glabrescens can be confused with Quercus ariifolia and Q. lancifolia, but it can be distinguished from the former by its glabrous or glabrescent abaxial blade surface, and the appressed acute unicellular trichomes located abaxially along the midvein; $Q$. ariifolia has the abaxial blade surface whitish-lanuginous and lacks acute unicellular trichomes. From $Q$. lancifolia it can be distinguished by its wider leaves (1.9-2.6 times longer than wider), and leaves with a rugose adaxial surface, while $Q$. lancifolia has narrower leaves (2.3-3.7 times longer than wider), and the adaxial surface is not rugose.

Quercus glaucoides M. Martens et Galeotti Bull. Acad. Roy. Sci. Brux. 10, pt. 1:209. 1843. Type: Mexico. Oaxaca, Mixteca Alta, Galeotti 103 (holotype: BR).

$=$ Quercus cordata M. Martens et Galeotti. $Q$. glaucophylla Seemen $Q$. baldoquinae Trel. $Q$. cancellata Trel. Q. harmsiana Trel. Q. conjungens Trel.

Trees 4-10 m tall; twigs 1-1.5 mm in diam., slightly furrowed, glabrous or with scarce stellate trichomes in the furrows, brown or slightly greenish to gray, lenticels inconspicuous; buds ovoid 1.5-2.8 mm long, scales broadly ovate, margin ciliate, brown, amber, to greyish; stipules linear or lanceolate, persistent or deciduous, 3.4-4.6 mm long, strigulose. Mature leaves with petioles (1.1) 1.9-7.5 $\times 0.8-2.2 \mathrm{~mm}$, glabrous or glabrescent with scarce stellate trichomes towards the base; blade coriaceous, obovate, elliptic, oblong to oblanceolate $5-11 \times 2.5-5 \mathrm{~cm}, 2.1-2.5$ times longer than wider; base rounded or subcordate sometimes cuneate; margin entire, crenate or with 1-5 mucronate teeth located above the base or in the distal half or distal third of the blade, not revolute; apex obtuse to rounded, tip mucronate, rarely emarginate; secondary veins (6) 7-9 on each side of the midvein, ascending, branching and anastomosing toward the margin, otherwise passing into the teeth if present; adaxial blade surface grayish green, dull, glabrous or glabrate with some scattered stellate trichomes, primary, secondary veins and veinlets barely prominent and slightly yellowish; abaxial blade surface glabrous or rarely with scarce and scattered stellate trichomes and hyaline glandular trichomes, epidermis papillose, dull, primary, secondary veins and veinlets more prominent than adaxially. Fruits annual, 1-4 on a glabrous peduncle ca. $44 \mathrm{~mm}$ long (Figure 4A).

Distribution and ecology. Endemic to Mexico, in the Sierra Madre del Sur and Transmexican Volcanic Belt; in the states of Guanajuato, Guerrero, Hidalgo, Jalisco, Mexico, Michoacan, Morelos, Nayarit, Puebla, Oaxaca, Queretaro and Zacatecas. Scarce and only distributed in the southwest of Hidalgo; in riparian gallery forests in transition with dry oak forests and in arid tropical scrub in transition with oak forests; asociated with Myrtillocactus geometrizans, Dodonaea viscosa and Calliandra sp.; at elevations from 1,721 to 2,150 m. Flowering time for Hidalgo state is unknown; fruits mature possibly in July.

Taxonomic comments. Quercus glaucoides can be recognaized easely by its glaucous, dull, and glabrous blades, the blade margin is entire, crenate or with 1-5 mucronate teeth. The fruits in the specimen revised are inmature, and so were not described.

Quercus greggii (A. DC.) Trel. Contributions from the United States National Herbarium 23(2): 185. 1922. Type: Mexico. Coahuila. San Antonio near Saltillo, $25^{\circ} 25^{\prime} 48^{\prime \prime} \mathrm{N}$ y $101^{\circ} 00^{\prime}$ 00" W, 31 aug- 1848. J. Gregg 380. (Isotype: MO). Basionym: Q. reticulata var. greggii A. DC. Prodromus Systematis Naturalis Regni Vegetabilis 16(2):34. 1864.

= Quercus aculcingensis Trel. Q. reticulata var. crassifolia Oerst. Q. loeseneri Trel.

Shrubs $4 \mathrm{~m}$ tall, rarely trees 4-6 $\mathrm{m}$ tall; twigs $1.5-4 \mathrm{~mm}$ in diam., densely pubescent, indument yellowish, with fasciculate sessile or shortly stipitate trichomes and some appressed acute unicellular trichomes, lenticels not visible; buds ovoid, 1-3.5 mm long, scales ovate to broadly 
ovate, pubescent, amber, margin ciliate; stipules lanceolate to linear, 5-7.5 mm long, tomentose, persistent. Mature leaves with petioles 3-8 $\times 1.5-3 \mathrm{~mm}$, pubescent with fasciculate sessile trichomes, brown to yellowish brown; blade markedly coriaceous and somewhat rigid, sometimes abaxially concave, obovate, oblong, elliptic to broadly ovate, sometimes suborbicular, (1.4) 2.5$5.3(6.5) \times(0.8-)$ 2.4-3.8 (4.5) cm, 1.2-1.7 (2) times longer than wider; base cordate, subcordate or rounded, margin markedly revolute, broadly crispate, entire, crenate or with 2-4 teeth located toward the apex; apex obtuse to rounded, tip mucronate or not; secondary veins 5-8 (10) on each side of the midvein which is sometimes zigzag and bifurcates towards the apex; adaxial blade surface dull, glaucous or yellowish, rugose, glabrescent with minute stellate trichomes towards the base of blade, along the midvein, secondary veins and towards the margin, veins impressed; abaxial blade surface densely tomentose or lanuginous, with fasciculate sessile or shortly stipitate trichomes, the rays intertwined and hiding the amber or reddish glandular trichomes, and the bullate and white-papillose epidermis; secondary veins and veinlets slightly prominent. Fruits annual, 1-3 sessile or on a tomentose peduncle 15-46 mm long, cupules hemispheric (11) 16-20 mm diam. $\times$ 6-7 (9) $\mathrm{mm}$ tall, margin erect, scales smooth, loosely appressed, lanceolatetriangular, slightly canescent; acorns ovoid, glabrous, 12-17 (22) mm long $\times 10-15 \mathrm{~mm}$ diam., included $1 / 3$ a $1 / 2$ of their total length in the cupule (Figure 4B).

Distribution and ecology. Endemic to Mexico, in the Sierra Madre Oriental and Mexican Plateau; in the states of Coahuila, Hidalgo, Nuevo Leon, Oaxaca, Puebla, Queretaro, San Luis Potosi, Tamaulipas, Veracruz and Zacatecas. In Hidalgo it is found in the center of the state, in oak forests and arid tropical scrub. Associated with Quercus ariifolia, $Q$. frutex, $Q$. mexicana and Q. rugosa; at elevations from 2,200 to 3,206 m. Flowering time for Hidalgo state is unknown; fruits mature from August to October.

Taxonomic comments. Quercus greggii can be confused with $Q$. ariifolia, especially when the latter is a sprout and looks like a shrub. However $Q$. greggii can be distinguished by its oblong to broadly obovate, coriaceous and rigid leaves, with a revolute and broadly crispate margin, the midvein is zigzag, the abaxial blade surface is densely tomentose, and because it is usually shrubby or sometimes a small tree (see also the taxonomic comments under Q. ariifolia).

Quercus grisea Liebm. Overs. Kongel. Danske Vidensk. Selsk. Forh. Medlemmers Arbeider 171. 1854. Type: USA. Western Texas, C. Wright 665, 1849, (isotype: MO).

$=$ Quercus undulata var. grisea $($ Liebm.) Engelm.

Trees 5-9 m tall; twigs 1.4-2 mm diam., barely furrowed, yellowish, densely velutinous, with stellate trichomes and fasciculate sessile trichomes, lenticels not visible; buds ovoid, subglobose or globose 2-2.7 mm long, scales ovate to broadly ovate, reddish, slightly canescent, margin ciliate; stipules persistent, lanceolate to linear or subulate 3.4-3.7 mm long, strigose. Mature leaves with petioles (2) 5-9 $\times 0.7-1.2 \mathrm{~mm}$, yellowish, densely velutinous with fasciculate sessile trichomes; blades subcoriaceous, oblong, elliptic, obovate, rarely ovate, (2) $4.5-7 \times 1-3 \mathrm{~cm}, 2.3$ 2.9 times longer than wider, base cordate, subcordate or rounded; margin slightly thick, entire, crenate or with 1-3 teeth towards the apex; apex obtuse to rounded; secondary veins 7-12 on each side of the midvein, ascending, straight or moderately curved, branching and anastomosing near the margin; adaxial blade surface dull, glaucous, wholly covered with scattered stellate trichomes, midvein, secondary veins and veinlets pale, flat or barely prominent, abaxial blade surface densely velutinous with two size stellate and appresed trichomes, the rays intertwined and hiding tiny and hyaline stellate trichomes, epidermis slightly bullate and waxy, secondary veins and veinlets prominent. Fruits annual, 1-2 on a peduncle 9-13 mm long; cupules hemispheric 8-15 mm diam. $\times$ (4) 7.5-8.9 mm tall, margin erect, scales thickened basally, appressed, canescent; acorns ovoid, glabrous, 10-16.5 (18) mm long $\times$ 7-12 mm diam., brown, included 1/2 to $1 / 3$ of their total length in the cupule (Figures $4 \mathrm{C}$ and $7 \mathrm{I}$ ).

Distribution and ecology. In northern and central Mexico; in the states of Aguascalientes, Chihuahua, Coahuila, Durango, Guanajuato, Hidalgo, Jalisco, Nuevo Leon, Puebla, Queretaro, San Luis Potosi, Sinaloa, Sonora, Veracruz and Zacatecas, reaching USA. In Hidalgo state it occurs 
in oak forests, pine forests, oak-pine forests and arid tropical scrub. Associated with Agave sp., Arbutus sp., Buddleja sp., Eysenhardtia sp. Karwinskia humboldtiana, Leonotis nepetifolia, Mimosa sp., Salvia sp. and Opuntia sp.; at elevations from 1,822 to 2,700 m. Flowering in April; fruits mature in September and October.

Taxonomic comments. Quercus grisea can be confused with Quercus microphylla and $Q$. frutex; however $Q$. grisea can be distinguished from both species by its tree habit, and densely velutinous leaves with appressed stellate trichomes which completely cover both surfaces. $Q$. microphylla and $Q$. frutex are shrubs and have leaves with fasciculate trichomes on the abaxial blade surface. Additionally $Q$. frutex has leaves with revolute margins while those of $Q$. grisea have flat margins.

Quercus hirtifolia Vázquez, Valencia et Nixon, Brittonia 56(2): 137. 2004. Type: Mexico. Puebla: Municipio Huauchinango. Venta Grande, on the rd. Huauchinango-Tulancingo, M. L. Vázquez Villagrán \& V. Vázquez Gordillo 3069 (holotype: MEXU; isotype: BH).

Shrubs 3-5 m or trees 7-15 m tall; twigs 1.6-3.5 in diam, furrowed, pale, pubescent becoming glabrescent, with stellate trichomes hiding the inconspicuous lenticels; buds ovoid or slightly conic 2.5-5 mm long, scales broadly ovate, amber, margin ciliate; stipules deciduous. Mature leaves with petioles $4-8 \times 1.17-2.5 \mathrm{~mm}$, pubescent to glabrescent, with stellate trichomes; blade coriaceous to subcoriaceous, obovate, elliptic, rarely ovate, (4) 6-8.5 (12) $\times 3.5-6.5(7.5) \mathrm{cm}$, 1.5-2 times longer than wider; base cordate to subcordate; margin with 2-4 aristate teeth located in the distal half or above base, rarely only aristate (without teeth), broadly crispate; apex obtuse or rounded, the tip aristate; secondary veins 7-9 (12) on each side of midvein, ascending, straight, branching and anastomosing towards the margin, otherwise passing into the teeth if present; adaxial blade surface dark green, slightly shiny, glabrous or glabrate, with scarce stellate trichomes along the midvein and secondary veins, which are impressed; abaxial blade surface with scattered fasciculate shortly stipitate trichomes, crowded towards the midvein and secondary veins, rarely glabrescent, epidermis slightly papillose. Fruits annual, 1-3 on a puberulent to tomentose peduncle 9-19 mm long; cupules hemispheric $12-13 \mathrm{~mm}$ diam. $\times$ ca. $6.4 \mathrm{~mm}$ tall, margin erect, scales smooth, closely appressed, pale tomentose; acorns ovoid, glabrous, 13 $14 \mathrm{~mm}$ long $\times 11-13 \mathrm{~mm}$ diam., included for about $1 / 2$ of their total length in the cupule (Figures $4 \mathrm{D}$ and $8 \mathrm{~A})$.

Distribution and ecology . Endemic to Mexico, in the southern part of the Sierra Madre Oriental; in the states of Hidalgo, Puebla and Veracruz. It occurs in southeastern Hidalgo state, usually in temperate and moist sites, in oak-pine forests and cloud forests. Associated with Fagus grandifolia subsp. mexicana, $Q$. corrugate, $Q$. delgadoana and $Q$. meavei; at elevations from 1,880 to 2,450 m. Flowering in April and May; fruits mature in September and October.

Taxonomic comments. Sometimes Quercus hirtifolia can be confused with Quercus laurina and $Q$. crassifolia, however $Q$. hirtifolia can be distinguished, by its annual fruits. Additionally $Q$. hirtifolia has scattered fasciculate shortly stipitate trichomes on the abaxial surface and lacks glandular trichomes; $Q$. laurina has fasciculate stipitate trichomes in the axils of the secondary veins, and in $Q$. crassifolia the abaxial blade surface is densely tomentose to woolly with fasciculate stipitate trichomes that intertwine and hide the epidermis. The latter two species have glandular trichomes on the abaxial surface.

Quercus laeta Liebm. Overs. Kongel. Danske Vidensk. Selsk. Forh. Medlemmers Arbeider, 179. 1854. Type: Mexico, Casa Grande, Hartweg 419 (holotype: B).

$=$ Quercus prinopsis Trel. $Q$. centralis Trel. $Q$. obscura Trel. $Q$. transmontana Trel. $Q$. pallescens Trel. Q. bipedalis Trel. Q. clivicola Trel. et C. H. Mull.

Trees 8-15 (25) m tall; twigs 1.5-2.3 (4) $\mathrm{mm}$ in diam., barely furrowed, floccose, indument slightly yellowish, with scattered fasciculate, sessile, appressed trichomes, lenticels not visible; buds ovoid (2) $2.7-4 \mathrm{~mm}$ long, scales broadly ovate, glabrous or tomentose, margin ciliate; stipules lanceolate and strigose, 2.2-5.4 mm long, deciduous, sometimes persisting on the apical 
buds. Mature leaves with petioles 6-8.7 (10) $\times$ 0.9-2 $\mathrm{mm}$, pubescent to glabrescent with fasciculate sessile appressed trichomes; blade coriaceous, oblong, oblanceolate to obovate (5.2) 6.5-9 (15) $\times(1.6) 2.4-3.7(4.5) \mathrm{cm},(1.7)$ 2.1-2.8 (3.8) times longer than wider; base cordate to subcordate; margin slightly thick and barely revolute, crenate or with 2-5 (8) mucronate short teeth located on the distal half or distal quarter of the blade; apex obtuse or rounded, occasionally acute; secondary veins 7-10 on each side of midvein, ascending, straight or moderately curved, branching and anastomosing towards the margin, otherwise passing into the teeth if present, adaxial blade surface dull, slightly rugose, glabrous or glabrate with scarce and scattered tiny stellate trichomes crowded towards the midvein and the margin, midvein and secondary veins impressed; abaxial blade surface pubescent, with fasciculate sessile trichomes, the rays crispate and sometimes slightly contorted, crowded near the midvein and secondary veins, epidermis white-papillose, visible through the trichomes, veins and veinlets prominent, slightly pale to yellowish, midvein with or without appressed acute unicellular trichomes. Fruits annual, 1-6 on a glabrous to glabrescent peduncle 14-18 mm long; cupules hemispheric 11-12 mm diam. $\times$ 6.6-7.5 mm tall, margin erect, scales triangular, canescent and strigose, basal scales moderately tuberculate and broader than the upper; acorns ovoid 12-12.5 mm diam. $\times 11.2-15 \mathrm{~mm}$ long, glabrous, yellowish, included $1 / 2$ to $1 / 3$ of their total length in the cupule (Figure 4E).

Distribution and ecology. Endemic to Mexico, widely distributed in north and central Mexico; in the states of Aguascalientes, Ciudad de Mexico, Coahuila, Colima, Durango, Guanajuato, Guerrero, Hidalgo, Jalisco, Mexico, Michoacan, Morelos, Nayarit, Nuevo Leon, Oaxaca, Puebla, Queretaro, San Luis Potosi, Sinaloa, Tamaulipas, Tlaxcala and Zacatecas. In Hidalgo state it occurs in oak forests, cloud forests, pine forests, pine-oak forests and bordering the arid tropical scrub. Associated with Acacia sp., Alnus sp., Fraxinus sp., Juniperus sp., Quercus castanea, Q. crassipes, $Q$. $\times$ dysophylla, $Q$. polymorpha, $Q$. rugosa, $Q$. sebifera, $Q$. sartorii and Salix sp.; at elevations from 1,250 to $2,780 \mathrm{~m}$. Flowering time for Hidalgo state is unknown; fruits mature in October.

Taxonomic comments. Quercus laeta shows extensive morphological variation throughout its distribution, which makes it a problematic species. In Hidalgo state Q. laeta can be distinguished by its abaxial blade surface which is covered with fasciculate sessile trichomes, lacks amber glandular trichomes, and usually has appressed acute unicellular trichomes along the midvein; the abaxial epidermis is white-papillose and appears glaucous; additionally the twigs are floccose.

Quercus lancifolia Schltdl. et Cham. Linnaea 5: 78. 1830. Syntypes: Mexico. Veracruz. Jalapa, Schiede 15, May (B); Mexico. Veracruz. Jalapa, Schiede 22, Oct; (B).

= Quercus leiophylla A. DC. Q. boqueronae Trel.

Trees 8-15 (20) m tall; twigs 1-2.5 mm in diam., slightly furrowed, pale to reddish, glabrous or scarcely puberulent with scarce and scattered fasciculate, stellate trichomes and acicular trichomes, lenticels pale; buds conic to ovoid, 2-3.5 mm long, scales broadly ovate, amber, glabrous, margin shortly ciliate or not; stipules deciduous or persistent on the apical buds, linear, lanceolate to filiform, strigose, 3.8-6.6 mm long. Mature blades with petioles (2.5) 3.1-6.0 (9) $\times 0.8-1.9 \mathrm{~mm}$, glabrous or glabrate with scarce and scattered fasciculate sessile trichomes and stellate trichomes; blades subcoriaceous, oblanceolate, elliptic, rarely oblong 4.4.-12.3 $\times(1.5)$ 2.8-4.7 cm, 2.3-3.7 times longer than wider; base cuneate, rounded or slightly subcordate; margin some crispate and revolute, with 3-7 mucronate teeth located in the distal half or third of the blade; apex acute or obtuse; secondary veins 10-14 on each side of midvein, ascending, straight or curved before the margin, passing into the teeth if present; adaxial blade surface slightly shiny, glabrous or with scarce fasciculate sessile trichomes and appressed acute unicellular trichomes along the midvein or at least towards the base, primary and secondary veins slightly impressed, veinlets barely notorious; abaxial blade surface glabrous or with scarce and scattered appressed acute unicellular trichomes along the midvein, epidermis slightly papillose, midvein and secondary veins prominent. Fruits annual, 1-2 on a glabrous or glabrescent peduncle 2.4-12 $\mathrm{mm}$ long; cupules hemispheric, $10.2-18 \mathrm{~mm}$ diam $\times$ 5.2-9 mm tall, margin erect, scales tuberculate, closely appressed, canescent; acorns ovoid to ellipsoid, glabrous to slightly pubescent 
towards the apex, 12.6-20 mm long $\times 9.5-12.7 \mathrm{~mm}$ diam., included $1 / 2$ to $1 / 3$ of their total length in the cupule (Figures $4 \mathrm{~F}$ and $8 \mathrm{~B}$ ).

Distribution and ecology. Quercus lancifolia is found in the Sierra Madre Oriental and southern Mexico; in the states of Hidalgo, Oaxaca, Puebla, Veracruz and Chiapas, reaching Guatemala, Costa Rica and Honduras. In Hidalgo state it occurs in pine-oak forests, moist oak forests, cloud forests and bordering pine forests. Associated with Alnus sp., Carpinus sp., Clethra sp., Fagus grandifolia subsp. mexicana, Liquidambar styraciflua, Quercus affinis, Q. delgadoana, Q. hirtifolia and Pinus patula; at elevations from 1,540 to 2,390 m. Flowering time for Hidalgo state is unknown; fruits mature in September and October.

Taxonomic comments. Quercus lancifolia can be distinguished from Q. corrugata, which it most resembles, by its oblanceolate leaves, fewer (10-14) secondary veins with 3-7 mucronate teeth located toward the apex, and small fruits (12.6-20 mm long $\times$ 9.5-12.7 mm diam.); Q. corrugata has elliptic or elliptic-lanceolate leaves with 11-18 secondary veins, and 8-16 mucronate teeth on each side of the blade located above the base, the fruits are up to $20-23 \mathrm{~mm}$ long $\times 15-20 \mathrm{~mm}$ diam. Linares (2003) and Berendsohn et al. (2009) consider these two as the same species under Quercus lancifolia Schltdl. et Cham.; however the differences mentioned above distinguish them; we therefore recognize these as two species.

Quercus laurina Bonpl., Pl. Aequinoct. 2, pt 10:32 pl. 80 . 1809. Type: Novae Hispaniae, [Mexico, Hidalgo], sur une montagne connue sous le nom de Cerro de las Nab[sic]ajas (montagne des Rasoirs), juxta Moran. eleve 800 toises [1,600 m snm], Bonpland 4143 (holotype: P!).

= Quercus lanceolata Bonpl. Q. chrysophylla Bonpl. Q.tridens Bonpl. Q. castanea var. tridens (Bonpl.) A. DC. Q. laurina var. barbinervis (Benth.) Wenzig. Q. tlapuxahuensis A. DC. Q. salicifolia var. tlapuxahuensis (A. DC.) Wenzig. $Q$. tlapuxahuensis var. obconica Trel. $Q$. caeruleocarpa Trel. Q. bourgaei Trel. Q. roseovenulosa Trel. Q. treleasana Camus. Q. nitens var. major A. DC. Q. laurina var. major (A. DC.) Wenzig. Q. major (A. DC.) Trel. Q. malinaltepecana Trel.

Trees 10-25 (30) m tall; twigs 1-2.5 (5) $\mathrm{mm}$ in diam., glabrescent with multiradiate stellate trichomes, lenticels pale and inconspicuous; buds globose to ovoid, 1.9-3.5 mm long, scales broadly ovate, amber, glabrous with a fimbriate margin; stipules deciduous. Mature leaves with petioles 6-17 $(20) \times 0.8-1.5 \mathrm{~mm}$, glabrescent with some stellate trichomes; blades coriaceous, dark-green, lanceolate, elliptic to oblanceolate 3.5-12.5 × 1.3-5.5 cm, 2-3.3 times longer than wider; base rounded, obtuse, occasionally truncate; margin entire or more frequently with 14 aristate teeth on each side of the blade located towards the apex; apex acute to obtuse, tip aristate; secondary veins 7-10 on each side of the midvein, moderately curved, branching and anastomosing near the margin, otherwise continuing directly into the tooth, if present, and continuing until the aristae; adaxial blade surface slightly dull or somewhat shining, glabrous or with scarce and scattered tiny multiradiate stellate trichomes towards the base of the midvein, secondary veins and veinlets flat or barely impressed; abaxial blade surface glabrescent, with tufts of fasciculate stipitate trichomes in the axils of the secondary veins and some scarce and scattered tiny multiradiate stellate trichomes and amber glandular trichomes towards the base of the blade, epidermis papillose, secondary veins and veinlets slightly prominent and yellowish. Fruits biennial, (1) 2-3 on a glabrous or glabrescent peduncle 5.4-8 mm long; cupules hemispheric, $10-17 \mathrm{~mm}$ diam. $\times 7-10 \mathrm{~mm}$ tall, margin erect, scales closely appressed, triangular, thickened basally; acorns ovoid, glabrous, 10-21 mm long $\times$ 0.8-15 mm diam., included ca. 1/3 of their total length in the cupule (Figure 4G).

Distribution and ecology. Endemic to Mexico, in the Transmexican Volcanic Belt and in the Sierra Madre del Sur; in the states of Aguascalientes, Ciudad de Mexico, Colima, Guanajuato, Guerrero, Hidalgo, Jalisco, Mexico, Michoacan, Morelos, Oaxaca, Puebla, Queretaro, Tlaxcala and Veracruz. In Hidalgo state it occurs in oak forests, pine-oak forests, pine forests and cloud forests. Associated with Abies religiosa, Arbutus sp., Quercus depressa, Q. frutex and Pinus sp.; at elevations from $(1,220) 1,600$ to 3,000 m. Flowering in February and March; fruits mature from September to November. 
Taxonomic comments. Quercus laurina shows a high morphological variation, but is constant in its amber glandular trichomes on the abaxiual leaf surface, tufts of fascicular stipitate trichomes in the axils of secondary veins, dull and dark-green leaves and the aristate teeth towards the apex of the blade. In some cases, Q. laurina can be confused with Quercus affinis (see taxonomic comments under $Q$. affinis) and with $Q$. trinitatis which has an entire blade margin, frequently presents leaves which are slightly asymmetric and slightly curved toward the apex.

Quercus meavei Valencia-A., Sabás and Soto. Phytotaxa 269(2): 120-126. 2016. Type: Mexico. Hidalgo, San Bartolo Tutotepec: $3 \mathrm{~km}$ al N de El Fresno, 98 $11^{\circ}$ N, 20 26'W, elev. 1,754 m, 25-ago-2012 (fr), Valencia \& Flores 5286b (holotype: FCME! isotype HUAP!).

Trees 20-30 m tall; twigs 2.2-2.5 (3) $\mathrm{mm}$ in diam., slightly fluted, glabrate or more frequently fulvo-tomentose, with fasciculate shortly stipitate trichomes towards the apex of twigs and the base of petioles, lenticels slightly pale, inconspicuous; buds long-ovoid, (4.5) 5.6-8.5 mm long, scales ovate, gray-yellowish to brown-yellowish, glabrate and shiny, margin irregularly ciliate, the upper scales golden and pilose; stipules deciduous or sometimes persisting at the apex of the twigs, linear to narrowly linear or oblanceolate, 6.5-8 (10) $\mathrm{mm}$ long, puberulent. Mature leaves with petioles (10) 23-36 (50) $\times$ 0.9-1.2 mm, glabrescent or more frequently fulvo-tomentose towards the base; blades coriaceous, lanceolate, oblong-lanceolate, oblanceolate, rarely elliptic, 13-18 × 4.5-7.5 cm, 2.4-3.5 times longer than wider; base obtuse or cuneate, sometimes slightly asymmetric; margin slightly thickened, crispate, with 11-16 long-aristate teeth on each side distributed from just above the base; apex acute or apiculate, tip aristate; secondary veins 14-17 (19) on each side of the midvein, parallel, ascending, almost straight, continuing into the tooth and until the arista; adaxial blade surface dull, glabrous or glabrate with scarce stellate trichomes towards the base of the midvein, primary and secondary veins impressed, veinlets flat; abaxial blade surface glabrous or glabrate with tufts of fasciculate stipitate trichomes in the axils of secondary veins, epidermis slightly papillose, primary and secondary veins prominent and pale yellow. Fruits biennial, 1-2 on a glabrous peduncle 6-13 mm long; cupules hemispheric, margin erect, (13) $18-23 \mathrm{~mm}$ diam $\times(8.5)$ 9.5-16.5 mm tall, scales lanceolate, sericeous, smooth and closely appressed; acorns ovoid, glabrous, $12-16.5 \mathrm{~mm}$ de tall $\times 11-16 \mathrm{~mm}$ diam., included $1 / 2$ to $1 / 3$ of their total length in the cupule (Figure $4 \mathrm{H}$ ).

Distribution and ecology. Endemic to Mexico, in the Sierra Madre Oriental, in the states of Hidalgo, Puebla, San Luis Potosi and Veracruz. In Hidalgo it occurs in cloud forest and moist oak forest; in very wet woodlands, along rivers and streams. Associated with Carpinus caroliniana, Clethra sp., Fagus grandifolia subsp. mexicana, Liquidambar styraciflua, Quercus corrugata, Q. delgadoana and Q. sartorii; in elevations from 1,230 to 2,160 m. Flowering in March; fruits mature from September to November.

Taxonomic comments. Quercus meavei is easily confused with $Q$. sartorii and $Q$.paxtalensis because all these species have glabrous or glabrate blades with dentate-aristate margins. However, its characteristic fruits maturing in two years and blades with a greater number of secondary veins (14-19) on each side of the midvein, separate it from related species in Hidalgo. Q. meavei was described recently; Valencia-A. et al. (2016) mentioned additional differences between $Q$. meavei and $Q$. sartorii, $Q$.xalapensis, $Q$. skinneri and $Q$. uxoris.

Quercus mexicana Bonpl., Pl. Aequinoct. 2: 35. 1809. Type: Mexico: Guanajuato, Santa Rosa, Bonpland 4218 (holotype: B).

$=$ Quercus castanea var. mexicana (Bonpl.) A. DC. Q. rugulosa M. Martens et Galeotti. $Q$. castanea var. integra Oersted. Q. imbricariifolia Trel. Q. malifolia Trel. Q. mexicana f. lanulosa Trel. Q. mexicana f. perfertilis Trel.

Trees (10) 12-15 m tall; twigs 1.5-2 mm in diam., brown to gray, glabrescent, with scarce stellate trichomes, lenticels inconspicuous; buds ovoid, 2-3 (6) mm long, scales broadly ovate, glabrous, margin ciliate; stipules deciduous or persistent on the apical buds, then linear, strigose, 3-5 mm long. Mature leaves with petioles 3-8 $\times 1-1.5 \mathrm{~mm}$, pubescent to glabrescent, with scarce fasciculate sessile trichomes; blades coriaceous, elliptic, lanceolate or oblong, 4-9 (12) 
$\times(0.9)$ 1.5-3.5 (4.2) cm, 2.5-3.5 times longer than wider; base cordate, subcordate or rounded, sometimes oblique; margin entire, slightly revolute; apex obtuse to rounded, tip aristate; secondary veins 10-13 (16) on each side of midvein, ascending, slightly curved or near straight, branching and anastomosing near the margin; adaxial blade surface dark green and slightly shiny, with some scattered stellate trichomes towards the base of the blade and the midvein; primary and secondary veins barely impressed, veinlets flat; abaxial blade surface paler than adaxial surface, glabrescent with fasciculate sessile contorted trichomes like dusty dots, rarely with some glandular trichomes, veins and veinlets prominent, epidermis papillose and slightly bullate. Fruits biennial, 1-2 sessile or on a glabrous peduncle 2-10 mm long; cupules hemispheric, $10-14.5 \mathrm{~mm}$ diam. $\times 8.3-10 \mathrm{~mm}$ tall, margin erect, scales smooth or thickened basally, pubescent, appressed, apex acute to rounded; acorns ovoid, glabrous or with scarce trichomes towards the apex, 9-15 mm long $\times 8-11 \mathrm{~mm}$ diam., included $1 / 3$ to $1 / 2$ of their total length in the cupule (Figure 5A).

Distribution and ecology. Endemic to Mexico, abundant in the central and eastern Transmexican Volcanic Belt and in the Sierra Madre Oriental; in the states of Ciudad de Mexico, Coahuila, Guanajuato, Hidalgo, Nuevo Leon, Mexico, Puebla, Queretaro, San Luis Potosi, Tamaulipas, Tlaxcala and Veracruz. In Hidalgo state it occurs in oak forests, pine forests, cloud forests, pineoak forests and thorn scrub. Associated with Alnus sp., Calliandra sp., Cupressus sp., Juniperus sp., Quercus affinis, Q. castanea, Q. crassifolia, Q. laeta, Q. laurina, Q. rugosa, Q. sebifera and Roldana sp.; at elevations from 1,250 to 2,859 m. Flowering in March and April; fruits mature from September to January.

Taxonomic comments. Quercus mexicana can be confused with $Q$. crassipes, but it can be distinguished by its fasciculate sessile contorted trichomes like dusty dots on the abaxial blade surface and the erect margin of the cupules. Additionally the secondary veins arise at an angle of less than $90^{\circ}$; in $Q$. crassipes the fasciculate trichomes are only crispate and stipitate, but are not contorted, the margin of the cupule is involuted, and the secondary veins arise at an angle near to $90^{\circ}$.

Quercus microphylla Née An. Ci. Nat. 3:264. 1801. Type: Mexico; Guanajuato. Née s.n. (MA!).

Shrubs ca. $1 \mathrm{~m}$ tall; twigs 0.9-1.6 mm in diam., tomentose, indument grayish, with fasciculate sessile trichomes; buds subglobose to broadly globose, 1.1-1.9 (2.5) $\mathrm{mm}$ long, scales ovate to broadly ovate, reddish, glabrate, margin ciliate; stipules deciduous, or persitent in the apical buds, so linear to filiform ca. $3.3 \mathrm{~mm}$ long, glabrous or strigose basally. Mature leaves with petioles (1.8) 2.2-3.4 × 0.6-1.2 (1.5) $\mathrm{mm}$, tomentose with fasciculate sessile trichomes and acicular unicellular trichomes; blade subcoriaceus, oblong to elliptic, $2-4 \times(0.7)$ 1-2.4 cm, 1.4-2.4 (2.8) times longer than wider; base subcordate, truncate or rarely rounded; margin thick or slightly revolute, entire or sometimes with 2-3 mucronate lobes on each side of the blade, towards the apex; apex obtuse or rounded, rarely emarginate; secondary veins 5-7 on each side of midvein, straight or slightly curved, ascending, branching and anastomosing near the margin; adaxial blade surface dull, sligthly rugose, glabrescent, with scattered stellate trichomes, with impressed primary and secondary veins; abaxial blade surface scattered or crowding covered with fasciculate sessile trichomes, the rays frecuently intertwined, veins and veinlets prominent and pale, epidermis papillosa and slightly bullate. Fruits annual, 1-2 on a tomentulose peduncle 8-9 $\mathrm{mm}$ long; cupule hemispheric, $12-14 \mathrm{~mm}$ diam. $\times 6-7 \mathrm{~mm}$ tall, margin erect, scales, triangular, tuberculate and canescent, closely appressed; acorns ovoid, 7-12 mm long $\times$ 7-10 mm diam., included ca. 1/3 of their total length in the cupule (Figure 5B).

Distribution and ecology. Endemic to Mexico, in the Transmexican Volcanic Belt; in the states of Hidalgo, Puebla, Tamaulipas, Tlaxcala, Veracruz and Zacatecas. In Hidalgo state it occurs in arid tropical scrub. Associated with Acacia schaffneri, Baccharis conferta, Dasylirion sp. and Mimosa aculeaticarpa; at elevations 2,440 m. Flowering and fructification time for Hidalgo state unknown. The description of fruits presented here is based on material from adjacent areas. 
Taxonomic comments. Quercus microphylla can be confused with $Q$. frutex, $Q$. grisea and $Q$. repanda; but it can be distinguished principally by its fasciculate sessile trichomes and lacks of glandular trichomes on the abaxial blade surface; being that $Q$. frutex has fasciculate stipitate trichomes on the abaxial blade surface; $Q$. grisea has stellate appressed trichomes covering the complete abaxial epidermis and $Q$. repanda presents fasciculate sessile trichomes and amber glandular trichomes on the abaxial blade surface.

Quercus obtusata Bonpl. Pl. Aequinoct. 2 :23 (26) pl. 76. 1809. Type: Mexico. Ario de Rosales, Bonpland $4329(\mathrm{P})$.

= Quercus pandurata Bonpl. Q. spicata Bonpl. Q. hartwegii Benth. Q. obtusata var. hartwegi (Benth.) A. DC. Q. obtusata var. pandurata (Bonpl.) A. DC. Q. pandurata var. hartwegi (Benth.) Wenz.Q. crenatifolia Trel.Q. panduriformis Trel. Q. rugosa sensu Trel. (not Q. rugosa Née). Q. alvarenzensis Trel. Q. atriglans Warb.

Trees 8-12 (15) m tall; twigs 1.8-2.8 (3.5) $\mathrm{mm}$ in diam., furrowed, glabrescent and slightly puberulent, with fasciculate sessile trichomes, reddish brown, lenticels inconspicuous; buds ovoid 3.3-3.7 mm long, scales broadly ovate, glabrous, margin ciliate, amber; stipules long-lanceolate or linear, sericeus, 5-8 mm long, generally deciduous. Mature leaves with petioles 3.2-11 (12.5) $\times$ 1.2-2 mm, glabrescent, with scattered stellate trichomes and fasciculate sessile trichomes; blade coriaceous or subcoriaceous, obovate or oblong, rarely elliptic, (4) 6-13 (16) $\times(3.5)$ 4-7.5 (9) cm, 1.3-2.5 times long than wide; base cordate, subcordate, rounded or truncate, margin thick, crenate or with 3-8 mucronate teeth in each side of the blade, located in the distal half, rarely entire; apex obtuse to rounded, tip mucronate; secondary veins (7) 9-13 on each side of the midvein, ascending, slightly curved, rarely straight, branching and anastomosing near the margin, otherwise continuing directly into the tooth if present and until the mucro; adaxial blade surface slightly rugose, dull or shiny, glabrous or glabrescens with scattered stellate trichomes and fasciculate sessile trichomes along the midvein, the rays crisped, primary, secondary veins and veinlets impressed; abaxial blade surface glabrescent, with scattered fasciculate sessile trichomes, the rays crispate and intermixed with yellowish to amber glandular trichomes, epidermis papillose and slightly bullate. Fruits annual, 3-5 on a glabrescent peduncle 19-30 mm long; cupules hemispheric, 11-16 mm diam. $\times$ 5-10 mm tall, margin erect, scales thickened and canescent basally; acorns globose, glabrous, 9-15 (16) mm long $\times$ 9-12.6 (13) mm diam., sometimes umbilicate in the apex, base with a black rim, included $1 / 2$ of their total length in the cupule (Figure 5C).

Distribution and ecology. Endemic to Mexico, in southern of Sierra Madre Occidental, in the Transmexican Volcanic Belt and in the Sierra Madre del Sur; in the states of Ciudad de Mexico, Colima, Guerrero, Guanajuato, Jalisco, Mexico, Michoacan, Morelos, Nayarit, Oaxaca, Puebla, Queretaro, San Luis Potosi, Tlaxcala, Veracruz and Zacatecas. In Hidalgo state it occurs in oak forests, pine-oak forest and in transition with arid tropical scrub. Associated with Quercus crassipes, $Q$. crassifolia, $Q$. dysophylla, Q. laeta, Quercus xylina and $Q$. rugosa; at elevations from 1242 to $2630 \mathrm{~m}$. Flowering time for Hidalgo state is unknown; fruits mature from September to November.

Taxonomic comments. In Hidalgo state $Q$. obtusata shows more glandular trichomes on the abaxial blade surface, and more fasciculate sessile trichomes on petioles and twigs in comparison with the specimens collected in central and southwestern Mexico. Quercus obtusata is easily confused with Quercus laeta, $Q$. xylina and $Q$. rugosa; but its glandular trichomes abaxially distributed, and wider blades distinguishe it from the first, from Q. xylina it can be distinguished by its coriaceous or subcoriaceous blades, flat blade margin, shorter peduncle (up to $30 \mathrm{~mm}$ long) and fewer fruits on the peduncle, from $Q$. rugosa it is distinguished by its flat blades (not concave abaxially), and the teeth have a very short apical mucro, never sharp.

Quercus oleoides Schltdl. et Cham., Linnaea 5: 79. 1930. Type: Mexico. Veracruz, near to Jalapa, Hacienda de la Laguna, Schiede 23 (holotype: B).

= Quercus lutescens M. Martens et Galeotti. Q. oleoides var. australis Trel. Q. oleoides $\mathrm{f}$. lutescens Trel. Quercus retusa Liebm. 
Trees 15-25 (30) m tall; twigs 1.6-2.6 (3) $\mathrm{mm}$ in diam., furrowed, tomentose, glabrescent to puberulent, with short stellate trichomes, grayish brown to yellowish brown, lenticels inconspicuous; buds globose or ovoid, 1-2.8 mm long, scales broadly ovate, shortly sericeous or glabrous, margin fimbriate, brown or reddish brown; stipules deciduous. Mature leaves with petioles (4) 6-10 (15) $\times 1.2-2 \mathrm{~mm}$ puberulent, with stellate trichomes; blade coriaceous, obovate to oblanceolate, elliptic or rhombic, 4-8.5 (14) $\times 2-4(7.2) \mathrm{cm},(1.5) 2-3.5$ times longer than wide; base cuneate, obtuse or attenuate; margin slightly revolute, entire, crenate or with 1-3 (5) teeth on each side of the blade, located in the distal half or distributed from just above the base, sometimes the teeth are mucronate; apex rounded, obtuse or rarely acute, tip mucronate; secondary veins 6-10 on each side of midvein, ascending, straight or moderately curved, branching and anastomosing near the margin; adaxial blade surface slightly shiny, olive-green, glaucous, glabrous or with scarce stellate trichomes towards the base of the blade and especially toward the midvein, with impressed primary and secondary veins; abaxial blade surface densely covered with stellate appressed trichomes hiding glandular trichomes, the indument yellowish gray to brownish gray, appearing glabrous to the naked eye, veins prominent, glabrous and brown, epidermis slightly papillose. Fruits annual, 1-2 (8) sessile or on a tomentose or puberulent peduncle 1-4 cm long; cupules turbinate, obconic or rarely hemispheric, $10-15 \mathrm{~mm}$ diam. $\times(8) 11-12 \mathrm{~mm}$ tall, margin erect, scales smooth, loosely appressed, gray, shortly sericeus; acorns ovoid, longovoid or elliptic, glabrous, $18-26 \mathrm{~mm}$ long $\times 9-14 \mathrm{~mm}$ diam., included $1 / 3$ to $1 / 4$ of their total length in the cupule (Figure 5D).

Distribution and ecology. Widely distributed in eastern Mexico, in the Sierra Madre Oriental; in the states of Campeche, Chiapas, Hidalgo, Nuevo Leon, Oaxaca, Puebla, Tamaulipas, San Luis Potosi and Veracruz, reaching Costa Rica. In Hidalgo state it occurs in tropical evergreen forests, semievergreen seasonal forests, cloud forest and oak forests; on yellow and clay soils; at elevations from 180 to 1,250 m. Flowering in May (only female flowers in specimens from Hidalgo state); mature fruits from September to December.

Taxonomic comments. Quercus oleoides is easily distinguished from other Hidalgo oaks by its bicolored leaves (olive-green adaxially, and gray-yellowish to gray-brownish abaxially). Aditionally the abaxial blade surface appears glabrous to the naked eye, but is fully covered with stellate appressed trichomes only observed under a microscope. In general, $Q$. oleoides occurs at lower altitudes than any other species in the genus. It is considered a species of tropical distribution.

Quercus opaca Trel. Mem. Natl. Acad. Sci. 20:92, pl. 148. 1924. Type Mexico, Hidalgo, Ixmiquilpan, R. Painter \& Rose 9030 (holotype: US!; isotype: NYBG!).

Shrubs 1-1.5 m tall; twigs 1-2 mm in diam., glabrescent or puberulent, gray to yellowish brown with stellate appressed trichomes, the rays short and crispate, lenticels inconspicuous; buds globose to rounded-ovoid, 0.8-1.7 mm long, scales broadly ovate, glabrate, brown to amber, margin fimbriate; stipules narrowly-triangular, strigose, $0.8-2.8 \mathrm{~mm}$ long, persistent or deciduous. Mature leaves with petioles 2.1-7.8 $\times 0.8-1 \mathrm{~mm}$, glabrescent with stellate trichomes, the rays crispate, slightly yellowish to reddish towards the base; blade coriaceous, oblong, elliptic or lanceolate, (2) 2.3-3 (4.7) $\times 10-15 \mathrm{~cm}, 1.7-2.7$ (3.3) times longer than wider; base cordate to subcordate, sometimes rounded; margin entire, rarely with 1-3 mucronate short teeth on each side, located towards the ápex; apex acute, obtuse or rounded, tip mucronate; secondary veins 7-10 on each side of midvein, ascending, straight or moderately curved near the margin; adaxial blade surface, dull, glaucous, glabrous or with scarce stellate trichomes towards the base of the blade and especially near the midvein, secondary veins flat and inconspicuous; abaxial blade surface glaucous and glabrous, except towards the base of blade and along the midvein which have scarce stellate trichomes, the rays crispate; midvein slightly yellowish and prominent, secondary veins barely prominent, almost inconspicuous, epidermis papillose and waxy near the midvein. Fruits annual, 1-2 on a glabrescent peduncle ca. $5 \mathrm{~mm}$ long; cupules hemispheric 10-11 mm diam. $\times$ 5.3-7.5 mm tall, margin erect, scales thickened basally, closely appressed, slightly tomentose; acorns ovoid, glabrous, ca. $9 \mathrm{~mm}$ long $\times$ ca. $8 \mathrm{~mm}$ diam., included 1/3 of their total length in the cupule (Figure 5E and 8D). 
Distribution and ecology. Endemic to Mexico, in the Mexican Plateau; in the states of Hidalgo, Nuevo Leon and San Luis Potosi. In Hidalgo state it occurs in arid tropical scrub. Associated with Eysenhardtia sp. and Pinus sp.; on yellow and clay soils; at elevations of 2,000 m. Flowering time for Hidalgo state is unknown; fruits mature in September.

Taxonomic comments. Quercus opaca can be confused with Quercus sebifera and Q.pringlei. It can be deistinguished from $Q$. sebifera by its oblong, elliptic or lanceolate leaves and the abaxial blade surface is not waxy; $Q$. sebifera has obovate leaves and the abaxial blade surface is waxy. $Q$. pringlei differs from $Q$. opaca in having narrower, oblong or narrowly-elliptic and bicolored leaves, the adaxial surface is olive green and shiny, while the abaxial surface is pale and dull.

Quercus paxtalensis C. H. Mull. U.S.D.A. Bur. Pl. Industr. Misc. Publ. 477: 75, pl. 113. 1942. Type: Mexico: Chiapas. Mount Paxtal [Pasitar] m 3-4 Aug. 1937, Matuda 1724 (holotype: MICH [digital image MICH1109345 JSTOR!]).

Trees 12-18 (30) m tall; twigs 1.9-3 mm in diam., glabrous, brown, slightly furrowed, lenticels whitish, conspicuous or inconspicuous; buds conic, ellipsoid or ovate, 3.5-4.9 mm long, scales broadly ovate, glabrous, gray to slightly brown, margin lacerate or entire; stipules deciduous. Mature leaves with petioles 20-40 $\times 0.9-1.1 \mathrm{~mm}$, glabrous; blade subcoriaceous to chartaceous, lanceolate or narrowly-elliptic, sometimes oblong, (7) $12-17$ (20) $\times(2.6) 3.2-5.5 \mathrm{~cm}, 2.7-3.7$ times longer than wider; base cuneate to rounded or truncate and asymmetric; margin with 9-12 long-aristate teeth on each side of the blade, distributed above the base, slightly crispate; apex acute or acuminate, tip aristate; secondary veins 10-12 (13) on each side of the midvein, ascending, straight, continuing into the tooth and until the arista, occasional evanescent intermediate veins are present near the base of the blade; adaxial blade surface glabrous, shiny, primary and secondary veins flat or barely prominent and yellowish or pale; abaxial blade surface glabrous, or rarely with tufts of fascicled stipitate trichomes in the axils of the secondary veins, epidermis slightly papillose or smooth, primary and seconday veins prominent. Fruits annual, 1-2 subsessile or on a glabrous peduncle 2-5 mm long; cupules turbinate 12.5-18 mm diam. $\times 10-13.5$ $\mathrm{mm}$ tall, margin erect, scales smooth, closely appressed, gray-canescent in the middle, margin brown; acorns ovoid, glabrous or with scattered tiny yellow trichomes, 18-20 mm long $\times 12-14$ mm diam., included $1 / 3$ of their total length in the cupule (Figure 5F).

Distribution and ecology. Endemic to Mexico, in the Sierra Madre Oriental and in the mountains of Chiapas; in the states of Chiapas, Hidalgo, Oaxaca, Tamaulipas and Veracruz. In Hidalgo state it occurs in moist oak forests and cloud forests. Associated with Clethra sp., Liquidambar styraciflua, Quercus corrugata, Q. delgadoana, Q. meavei and Podocarpus sp.; at elevations from 1,110 to $1,750 \mathrm{~m}$. Flowering time for Hidalgo state is unknown; fruits mature from August to October.

Taxonomic comments. Quercus paxtalensis can be confused with Quercus sartorii and $Q$. meavei, however it can be distinguished by its turbinate and bigger cupule, shiny leaves and the blade margin presents teeth which are distributed from just above the base; in $Q$. sartorii the leaves are only slightly or scarcely shiny, and the teeth of the margin are located in the distal half or distal $2 / 3$ of the blade. Q. meavei has biennial fruits, a greater number of secondary veins on each side of midvein (13-18) and these are impressed adaxially; whereas $Q$. paxtalensis has annual fruits, and 10-13 secondary veins which are slightly prominent adaxially. The sprout leaves in $Q$. paxtalensis have shorter petioles (0.7-15 $\mathrm{mm}$ long).

Quercus pinnativenulosa C. H. Mull. J. Arn. Arb. 17:171. 1936. Type: Mexico. Nuevo León, municipio De Villa Santiago, Cañon Guajuco above Villa Santiago, Muller 1342 (holotype: A, isotype: MEXU!).

Trees 15-25 m tall; twigs 1.4-2 (3) mm in diam., glabrous, grayish, slightly furrowed, lenticels inconspicuous; buds conic to ovoid, 3-4.5 mm long, scales broadly ovate, grayish, glabrous margin reddish and ciliate; stipules deciduous. Mature leaves with petioles (5) $8-17 \times 1-1.5 \mathrm{~mm}$, glabrous; blade subcoriaceous to chartaceous, elliptic, oblong to oblanceolate (5.2) 7.5-13.5 $\times$ 1.8-3.5 cm, 3.2-4.4 times longer than wider; base cuneate, rarely rounded; margin entire, rarely 
with 1-2 shortly aristate teeth near the apex, slightly and broadly crispate, slightly revolute only in the oldest leaves; apex acute or acuminate, tip aristate; secondary veins (8) 13-18 on each side of midvein, often arising at an angle greater than $45^{\circ}$ respect to midvein, straight or moderately curved, branching and anastomosing before the margin; adaxial blade surface glabrous, shiny, secondary veins and veinlets flat and inconspicuous; abaxial blade surface glabrous, sometimes with scarce stellate trichomes towards the base of the blade, midvein prominent, secondary veins and veinlets almost flat or barely prominent, epidermis slightly papillose or flat-papillose. Fruits biennial, 1-2 on a glabrous peduncle 5.7- $8 \mathrm{~mm}$ long; cupules hemispheric or sometimes turbinate, 7.6-10 mm diam. $\times$ 6.3-9.6 mm tall, margin erect, scales smooth and closely appressed, gray-canescent; acorns ovoid, glabrous, 14-19 mm long × 8.6-9.6 mm diam., included $1 / 3$ of their total length in the cupule (Figure $5 \mathrm{G}$ ).

Distribution and ecology. Endemic to Mexico, in the Sierra Madre Oriental and Sierra Norte of Oaxaca; in the states of Hidalgo, Nuevo Leon, Oaxaca, Puebla, Queretaro, San Luis Potosi, Tamaulipas and Veracruz. In Hidalgo state it is a scarce species, in pine-oak forests, moist oak forests and cloud forests; at elevations from 1,100 to 1,432 m. Fowering time for Hidalgo state unknown; fruits mature in October.

Taxonomic comments. Quercus pinnativenulosa is distinguished from $Q$. delgadoana by its leaves with a flat, not revolute, margin, shiny adaxially and with secondary veins flat (not impressed); Q. delgadoana has leaves with a revolute margin, dull and glaucous adaxially and the veins are impressed on the adaxial blade surface.

Quercus polymorpha Schltdl. et Cham. Linnaea 5: 78. 1830. Type: Mexico, Veracruz, Hacienda de la Laguna, near Jalapa, Schiede 20 (syntype: C!).

$=$ Quercus petiolaris Benth. Q. varians M. Martens et Galeotti. Q. guatimalensis A. DC. $Q$. turbinata Liebm. (not Q. turbinata Blume). Q. germana var. lemmonii Trel. Q. polymorpha $\mathrm{f}$. angustifolia $\mathrm{C}$. H. Mull.

Trees 4-16 (20) m tall; twigs 2-3 (5) mm in diam., furrowed, grayish brown, yellowish or slightly reddish, glabrous or with scarce yellow stellate trichomes which break off easily, lenticels pale, inconspicuous; buds ovoid or conic, 2-3 (7) mm long, scales reddish brown, glabrous or slightly strigose towards the apex; stipules deciduous or persisting on the apical buds, then narrowly-triangular and strigulose, 1-1.5 mm long. Mature leaves with petioles (3.5) 14-26 (30) $\times 1-1.7 \mathrm{~mm}$, yellow to gray, glabrate, with scarce yellow stellate trichomes; blades coriaceous, lanceolate, elliptic, ovate or obovate, (5.5) 7-18 × (2.4) 3-7 (9.2) cm, 1.6-2.8 times longer than wider; base rounded, subcordate, truncate or oblique; margin entire or with 1-5 mucronate teeth or lobes on each side distributed in the distal half or third of the blade, revolute; apex obtuse, rounded, sometimes emarginate; secondary veins (8) 10-14 on each side of the midvein, ascending, moderately curved, branching and anastomosing near the margin; adaxial blade surface, glaucous or gray-green, barely shiny, secondary veins and veinlets impressed; abaxial blade surface glaucous, dull, glabrous or with tufts of fasciculate stipitate trichomes in the axils of the secondary veins and near the midvein, scarce and scattered hyaline glandular trichomes present or not, epidermis with white papillae and slightly waxy, veins and veinlets yellowish. Fruits annual, 1-2 on a axillary glabrous peduncle 10-20 mm long; cupules hemispheric, 12-18 (29) mm diam. $\times$ (7) 8-11 (13) $\mathrm{mm}$ tall, margin erect rarely involute, scales closely appressed, tuberculate basally, gray-canescent; acorns ovoid, glabrous or rarely with scarce golden stellate trichomes towards the apex (12) 17-18 mm long $\times 9-13 \mathrm{~mm}$ diam., included $1 / 2$ of their total length in the cupule (Figure $5 \mathrm{H}$ and $8 \mathrm{E}$ ).

Distribution and ecology. Widely distributed from the southern USA, Mexico and reaching Guatemala; in the states of Chiapas, Hidalgo, Nuevo Leon, Oaxaca, Puebla, Queretaro, San Luis Potosi, Tamaulipas and Veracruz. In Hidalgo state it occurs in cloud forests and dry oak forests in transition with arid tropical scrub, and juniper-oak forests. Associated with Bursera sp., Erythrina sp., Quercus mexicana and Q. laeta; at elevations from 850 to 2,200 m. Flowering time for Hidalgo state is unknown; fruits mature in September and October. 
Taxonomic comments. Quercus polymorpha can be confused with Quercus germana, however it is distinguished by its yellowish and longer petioles (14-30 mm long), the size of acorns (17-18 $\mathrm{mm}$ long), and the fruits which are on a peduncle in the axils of the leaves. On the other hand $Q$. germana has petioles from 3-6 mm long, the acorns are $28-40 \mathrm{~mm}$ long, and the fruits are on a peduncle located at the apex of the twigs.

Quercus pringlei Seemen, Bot. Jahrb. Syst. 20(1): 96. 1900. Type: Mexico. Coahuila, Carneros Pass, limestone hills, Pringle 2382. (isolectotype: MO).

\section{= Quercus filiformis C. H. Mull. Quercus pringlei $\mathrm{f}$. dentata $\mathrm{C} . \mathrm{H}$. Mull.}

Shrubs 1.5-3 m tall or small trees 3-5 m tall; twigs 1-2 mm in diam., slightly furrowed, brown to grayish, glabrous, glabrescent or puberulent with fasciculate sessile appresses trichomes, lenticels inconspicuous; buds globose to ovoid, 1-3 mm long, scales ovate to broadly ovate, brown, glabrous, margin ciliate; stipules tardily deciduous, persistent on the apical buds, filiform, lanceolate or long-triangular, 3-5 mm long, glabrous. Mature leaves with petioles 2.5-5.7 $\times 0.7-1.3 \mathrm{~mm}$, glabrate with scarce and scattered yellowish to reddish stellate trichomes; blades coriaceous and rigid, oblong to lanceolate or narrowly elliptic, (1.1) 2-3.7 × (0.6) 0.8-1.3 (2.8) $\mathrm{cm}, 1.6-2.5$ (3.4) times longer than wider; base subcordate to rounded; margin slightly thick, entire; apex obtuse or rounded, tip mucronate; secondary veins (6) 7-9 (10) on each side of the midvein, ascending, straight or moderately curved near the margin, branching and anastomosing near the margin; adaxial blade surface shiny, sometimes sparsely stellate-pubescent along the midvein, secondary veins almost flat, only evident near the midvein, midvein slightly impressed towards the base; abaxial blade surface dull, glaucous, glabrous or with scarce stellate trichomes scattered near the midvein and base of the blade, primary, secondary veins and veinlets paleyellowish, barely prominent and inconspicuous. Fruits annual, 1-4 subsessile or on a glabrous peduncle 5-23 mm long; cupules hemispheric, 8-10 $\mathrm{mm}$ de diam. $\times 4-6 \mathrm{~mm}$ tall, margin erect, scales tuberculate, closely appressed, canescent, apex dark-brown; acorns elliptic 8-12 mm long $\times 9-10 \mathrm{~mm}$ diam., glabrous, light brown, barely grooved, included $1 / 2$ of their total length in the cupule (Figure 5I).

Distribution and ecology. Endemic to Mexico, in the Sierra Madre Oriental and in the southern part of the Mexican Plateau; in the states of Coahuila, Durango, Hidalgo, Nuevo Leon, Queretaro, San Luis Potosi, Tamaulipas and Zacatecas. In Hidalgo state it occurs in arid tropical scrub, xerophilic scrub, and in juniper-oak forests; at elevations from 1,800 to 2,200 m. Flowering time for Hidalgo state is unknown; fruits mature in October and November.

Taxonomic comments. Quercus pringlei can be confused with Quercus opaca (see taxonomic comments under Q. opaca).

Quercus repanda Bonpl. Pl. Aequinoct. 2:31, pl. 79. 1809. Type: Mexico, Real del Monte to Moran, at 2516, Bonpland 4081 (holotype: P).

= Quercus revoluta Trel. Q. lecompteana Trel. Q. subtriloba Trel..

Shrubs 0.2-1.5 (3) m tall; twigs 1.7-2.5 (3.5) $\mathrm{mm}$ in diam., tomentose with short stellate trichomes intermixed with fasciculate sessile trichomes, glabrescent in the second year, then with pale inconspicuous lenticels; buds ovoid to globose (0.6) 1-1.3 (3) mm long, sometimes inconspicuous, scales ovate to broadly ovate, reddish, glabrate, margin ciliate; stipules persistent, linear to long-lanceolate or long-oblanceolate, 3.6-6 mm long, strigose, rigid. Mature leaves with petioles 3.5-7 $\times 0.8-1.8 \mathrm{~mm}$, tomentose with stellate trichomes and fasciculate sessile trichomes; blade coriaceous, oblanceolate to obovate, elliptic or oblong, 2.8-6 (10) $\times 1.0-2.1(4.5) \mathrm{cm}, 2.1$ 2.6 (3.3) times longer than wider, base cuneate to rounded, margin revolute, entire, repand, crenate or sometimes with 2-3 teeth on each side of the blade near the apex; apex obtuse or rounded, tip mucronate; secondary veins 5-9 on each side of the midvein, straight or moderately curved, ascending, branching and anastomosing towards the margin; adaxial blade surface dull, rugose, grayish green, glabrate with scattered stellate trichomes towards and along the midvein, primary and secondary veins impressed; abaxial blade surface densely tomentose to lanuginous, indument yellowish to light brown, with fasciculate sessile trichomes, the rays intertwined and in- 
termixed with amber glandular trichomes, veins and veinlets prominent and slightly brown, epidermis bullate and papillose. Fruits annual, 2-3 on a tomentose peduncle 1-2.5 cm long; cupules hemispheric, $10-15 \mathrm{~mm}$ diam. $\times 5-8 \mathrm{~mm}$ tall, margin erect, scales tuberculate, closely appressed, amber, canescent basally, margin fimbriate; acorns ovoid to broadly ovoid, 12-14 mm long $\times 9$-11 mm diam., glabrous, included $1 / 2$ of their total length in the cupule (Figure $6 \mathrm{~A}$ and $8 \mathrm{~F}$ ).

Distribution and ecology. Endemic to Mexico, in the Sierra Madre Oriental and Transmexican Volcanic Belt; in the states of Guanajuato, Hidalgo, Michoacan, Puebla, Queretaro, San Luis Potosi and Veracruz. Widely distributed in Hidalgo state; forming large patches in the pine forests, pine-oak forests, oak forests and arid tropical scrub. Associated with Agave sp., Arbutus sp. Baccharis sp., Cupressus sp., Opuntia sp., Pinus sp., Quercus depressa, Q. eduardi, Q. laurina and $Q$. mexicana; at elevations from $(1,100) 2,100$ to 3,140 m. Flowering in May; fruits mature in September and October.

Taxonomic comments. Specimens of Quercus repanda can be confused with Quercus greggii and $Q$. frutex. However it is easily distinguished by its coriaceous, oblanceolate to obovate, elliptic or oblong leaves, revolute blade margin, and cuneate to rounded base; $Q$. greggi has markedly coriaceous and somewhat rigid leaves, additionally these are obovate, oblong, elliptic to broadly ovate, sometimes suborbicular, concave abaxially with broadly crispate margin, and subcordate, cordate or sometimes rounded base. From $Q$. frutex, it is distinguished by its yellowish abaxial blade surface with amber glandular trichomes and fasciculate sessile trichomes; $Q$. frutex has the abaxial blade surface whitish, without glandular trichomes, and has fasciculate stipitate trichomes on the abaxial surface.

Quercus rugosa Née Anales Ci. Nat. 3: 275. 1801. Type: Mexico. Estado de Mexico. Huixquilucan y Ocuilan de Arteaga, Née s.n. (Syntypes: MA!).

$=$ Quercus reticulata Bonpl. Q. decipiens M. Martens et Galeotti. Q. vellifera Trel. Q.durangensis Trel. Q. diversicolor Trel. Q. rhodophlebia Trel. Q. reticulata f. dugesi Trel. Q. reticulata f. squarrosa Trel. Q. reticulata f. longa Trel. Q. uhdeana Trel. Q. conglomerata Trel. Q. purpusii Trel. Q. innuncupata Trel. Q. suchiensis Warb.

Trees 12-18 (25) m tall; twigs (1.5) 2-3.8 (4.4) $\mathrm{mm}$ in diam, slightly furrowed, glabrate or glabrescent with fasciculate sessile trichomes, yellowish brown to reddish brown, lenticels pale, conspicuous or hidden by the indument; buds ovoid 1.2-3.6 mm long, scales very broadly ovate, glabrous or glabrescent, amber, margin ciliate; stipules narrowly triangular to long-lanceolate, 2.5-6 (9) mm long, glabrescent or strigose. Mature leaves with petioles (4.5) 6-10.5 mm long $\times 1.4-2.7 \mathrm{~mm}$ diam., reddish brown basally, glabrescent, with fasciculate sessile trichomes, the rays crispate; blades coriaceous, slightly rigid, concave abaxially and convex adaxially, obovate, panduriform or elliptic, rarely suborbicular (4.3) 7-15 (-18) × (1.4) 3.2-11.5 (13) cm, 1.4-2 times longer than wider; base cordate or subcordate; margin revolute, crenate or with 4-7 sharply mucronate teeth on each side of the blade, sometimes only mucronate (without teeth); apex obtuse or rounded, sometimes retuse; secondary veins 7-16 on each side of the midvein, ascending and moderately curved, branching and anastomosing near the margin, the upper continuing directly into the tooth and until the mucro, occasionally some veins evanescent and intermediates are present; adaxial blade surface glaucous or dark-green, somewhat shiny, prominently rugose, glabrate or glabrescent, sometimes with sparsely fasciculate sessile trichomes along the midvein, with primary, secondary veins and veinlets impressed; abaxial blade surface dull, glaucous, slightly pubescent to glabrescent, with scattered fasciculate sessile trichomes, the rays crispate, intermixed with amber glandular trichomes, veins and veinlets prominent, epidermis bullate and papillose. Fruits annual, 2-13 on a glabrescent or glabrate peduncle (10) $16-180 \mathrm{~mm}$ long; cupules hemispheric 10-17 mm diam. $\times 5-6$ (9) mm tall, scales triangular, apex acute, smooth and appressed, slightly canescent; acorns ovoid, glabrous $15-16 \mathrm{~mm}$ long $\times$ 7.5-13.5 $\mathrm{mm}$ diam., included $1 / 4$ to $1 / 3$ of their total length in the cupule (Figure $6 \mathrm{~B}$ ).

Distribution and ecology. Widely distributed from the southern United States of America to Central America; in the states of Aguascalientes, Chiapas, Chihuahua, Ciudad de Mexico, Coa- 
huila, Colima, Durango, Guanajuato, Hidalgo, Jalisco, Mexico, Michoacan, Morelos, Oaxaca, Puebla, Queretaro, Sonora, Sinaloa, Tlaxcala, Veracruz and Zacatecas. In Hidalgo state it occurs in pine forests, oak forests, pine-oak forests, cloud forests, and oak forests in transition with arid tropical scrub. Associated with Abies sp., Eysenhardtia sp., Mimosa sp., Opuntia sp., Pinus oocarpa, P. teocote, P. engelmannii, Prunus sp. Pseudotsuga sp., Quercus affinis, Q. glabrescens, $Q$. castanea, $Q$.crassipes, $Q$. crassifolia, $Q$.laurina, $Q$. mexicana and Yucca sp.; at elevations from $(2,177) 2,410$ to $2,949 \mathrm{~m}$. Flowering time for Hidalgo state is unknown; fruits mature from September to November.

Taxonomic comments. Quercus rugosa is one of the more polymorphic species of Mexico. In Hidalgo $Q$. rugosa can be confused with $Q$. ariifolia and $Q$. greggii. Diagnostic features of $Q$. rugosa include the presence of a glaucous, bullate and papillose epidermis on the abaxial blade surface; obovate, elliptic or suborbicular leaves which are concave abaxially, and the blade margin with sharply mucronate teeth.

Quercus rysophylla Weath., Proc. Amer. Acad. Arts 45(17): 423-424. 1910. Type: Mexico, Nuevo León: Sierra Madre above Monterrey, Pringle 10225, mar 1906 (lectotype: GH).

Trees 12-20 m tall; twigs 2.1-3.7 mm in diam., slightly furrowed, brown, glabrate with scarce and scattered stellate trichomes in the furrows, lenticels inconspicuous; buds ovoid, 2.8-3.5 mm long, scales broadly ovate, almost glabrous or strigulose, amber, margin ciliate; stipules persistent, narrowly lanceolate to oblanceolate, 3.5-7.4 mm long, strigose. Mature leaves with petioles (1.7) 3.3-6.2 $\times 1.6-2.3 \mathrm{~mm}$, brown to brown-yellowish, adaxially with scarce stellate trichomes; blades subcoriaceous or chartaceous, elliptic, oblanceolate or obovate, (6.5) $10.5-18.5 \times(2.5) 3.5-7 \mathrm{~cm}$, 2.6-3 times longer than wider; base cordate to subcordate; margin thickened or revolute, entire or sometimes with 2-4 aristate teeth on each side of the blade, distributed towards the apex or distal forth of the blade, sometimes only aristate (without teeth); apex acute to obtuse, sometimes acuminate; secondary veins 11-16 on each side of the midvein, ascending and moderately curved near the margin, branching and anastomosing before the margin; adaxial blade surface shiny, prominently rugose, glabrous or glabrate with scarce stellate trichomes towards the base of the blade and near the midvein, midvein, secondary veins and veinlets markedly impressed; abaxial blade surface, glabrate with tufts of fasciculate shortly stipitate trichomes in the axils of secondary veins, sometimes with scarce and scattered glandular trichomes, veins and veinlets prominent and yellowish, epidermis papillose, abaxially less shiny than adaxially. Fruits biennial, 1-3 sessile or on a glabrous and short peduncle 3-6.5 mm long; cupules hemispheric, $10.5-13.5 \mathrm{~mm}$ diam. $\times$ 9.5$11.5 \mathrm{~mm}$ tall, margin erect, scales rounded, smooth, slightly canescent, closely appressed; acorns ovoid to elliptic, 13-17.5 mm long $\times 10.6-12 \mathrm{~mm}$ diam., glabrescent, with scarce and tiny golden trichomes, included $1 / 3$ to $1 / 2$ of their total length in the cupule (Figure 6C).

Distribution and ecology. Endemic to Mexico, in the Sierra Madre Oriental; in the states of Hidalgo, Queretaro, Nuevo Leon, San Luis Potosi, Tamaulipas and Veracruz. In Hidalgo state it occurs in cloud forests and oak forests. Associated with Clethra sp., Dodonaea viscosa, Juniperus flacida, J. monosperma, Karwinskia latifolia, Pinus cembroides and Pistacia mexicana; at elevations from 820 to 1,965 m. Flowering in May; fruits mature in October and November.

Taxonomic comments. Quercus rysophylla can be confused with Quercus castanea, however it can be distinguished by its shiny adaxial blade surface, veins and veinlets markedly impressed adaxially (with prominently rugose appearance), the abaxial blade surface is glabrous except for tufts of fasciculate stipitate trichomes in the axils of the secondary veins, the epidermis is papillose and the fruits are biennial; $Q$. castanea has a dull or scarcely shiny adaxial blade surface, veins and veinlets slightly impressed adaxially, the abaxial blade surface is glabrescent or densely pubescent with fasciculate sesile trichomes, the abaxial epidermis is bullate and the fruits are annual.

Quercus sapotifolia Liebm., Overs. Kongel. Danske Vidensk. Selsk. Forh. Medlemmers Arbeider. 185. 1854. Type: Costa Rica, Skinner 6. 
= Quercus microcarpa Liebm. (Not Q. microcarpa Lapeyrouse). Q. elliptica $\beta$ microcarpa A. DC. (pro part). Q. guatimalensis A. DC (pro part). Q. parviglans Trel $Q$. parviglans f. polycarpa Trel. Q. parviglans f. tejadana Trel. Q. apanecana Trel. $Q$. donnell-smithii Trel. (pro part). $Q$. wesmaeli Trel. (pro part). Q. siguatepequeana Trel. Q. amissaeloba Trel. Q. perseaefolia var. achoteana Trel.

Trees ca. $15 \mathrm{~m}$ tall; twigs 2-3.5 $\mathrm{mm}$ in diam., furrowed, glabrous, reddish brown, lenticels inconspicuous; buds ovoid, 1.8-3 mm long, brown to yellowish or amber, scales broadly ovate, glabrous, margin fimbriate; stipules deciduous. Mature leaves with petioles 3.4-6 $\times 1.7-2.5 \mathrm{~mm}$, glabrous or glabrate adaxially with stellate trichomes; blades coriaceous or thick-coriaceous, oblanceolate, oblong, or elliptic, 8-12.5 (24.5) × 2.1-4 (9) cm, 2.5- 3.4 times longer than wider; base cuneate, sometimes rounded; margin entire and revolute, broadly crispate or not; apex obtuse to rounded, tip aristate or not; secondary veins 8-11 (14) on each side of the midvein, ascending and curved, branching and anastomosing before the margin; adaxial blade surface glabrous, shiny, veins and veinlets flat or barely impressed and slightly yellowish; abaxial blade surface shiny, glabrous or glabrate, with tufts of fasciculate stipitate trichomes in the axils of the secondary veins, primary and secondary veins yellowish and prominent, epidermis flat or barely papillose. Fruits annual, 1-3 on a glabrous peduncle 2-10 mm long, cupules hemispheric to slightly turbinate, $8-10 \mathrm{~mm}$ diam. $\times 5-6 \mathrm{~mm}$ tall, scales broadly ovate, smooth and closely appressed; acorns ovoid to long-ovoid, barely pubescent or glabrous, $8-12 \mathrm{~mm}$ long $\times 7-8.5 \mathrm{~mm}$ diam., included $1 / 3$ to $1 / 4$ of their total length in the cupules (Figure 6D).

Distribution and ecology. Found in southern Mexico, in the Sierra Madre Oriental; in the states of Chiapas, Hidalgo, Oaxaca, Puebla, San Luis Potosi and Veracruz; also in Central America, in Belize, Costa Rica, El Salvador, Guatemala, Honduras and Panama. In Hidalgo state it is scarce, in moist oak forests and cloud forests; at elevations from 710 to $1,000 \mathrm{~m}$. Flowering in November; fructification time for Hidalgo state unknown (description of fruits taken from Muller, 1942). The flowering in Hidalgo is atypical, because most Quercus species flower from February to May.

Taxonomic comments. Quercus sapotifolia can be confused with Quercus delgadoana, but can be distinguished by its annual fruits; the leaves are shiny, green or yellowish green, oblanceolate, oblong or elliptic, with 8-14 secondary veins on each side of midvein; $Q$. delgadoana has biennial fruits, the leaves are grayish green or glaucous, narrowly oblong, lanceolate or elliptic, and have 9 to 20 secondary veins on each side of midvein.

Quercus sartorii Liebm., Overs. Kongel. Danske Vidensk. Selsk. Forh. Medlemmers Arbeider. 177. 1854. Type: Mexico. Veracruz, Totutla, Liebmann 3554, Aug 1841, 4000’ (isolectotype $\mathrm{C}$ !).

= Quercus sartorii f. magna Trel.

Trees 10-25 m tall; twigs 1.2-2.5 mm in diam., slightly furrowed or terete, greyish to brown, glabrous or slightly puberulent with scarce and tiny stellate trichomes, lenticels inconspicuous; buds conic, ovoid or elliptic, (2) 3.3-4.8 mm long, scales broadly ovate, glabrous, margin ciliate, amber; stipules deciduous. Mature leaves with petioles (6) 11.4-18 (24) $\times 1.2-2 \mathrm{~mm}$, glabrous or with scarce yellowish stellate trichomes; blades coriaceous, elliptic, ovate or lanceolate, (6) 8.8-14 × 2.2-4.4 (5.4) cm, (1.9-) 2.2-2.5 (2.9) times longer than wider; base rounded or truncate, rarely cuneate, sometimes asymmetric, margin thick, flat or barely crispate, with (3) 6-8 aristate short teeth, sometimes only aristate (without teeth), distributed above the base or in the distal 2/3; ápex acute, tip aristate; secondary veins 7-12 on each side of the midvein, ascending, straight, branching before reaching the margin or continuing towards the tooth and until the arista if it is present; adaxial blade surface scarcely shiny or dull, glabrous or glabrate with stellate trichomes over the base of the midvein, secondary veins flat or barely impressed; abaxial blade surface glabrous or glabrate, with tufts of fasciculate stipitate trichomes in the axils of the secondary veins and scarce stellate multiradiate trichomes near the midvein, epidermis papillose, primary, secondary veins and veinlets prominent and slightly yellowish. Fruits annual, 1-2 subsessile or on a glabrous peduncle 2-10 mm long; cupules hemispheric or slightly obconic, 
8.6-12 mm diam. $\times 6-10 \mathrm{~mm}$ tall, margin erect, scales smooth and closely appressed, triangular, canescent; acorns ovoid, glabrous, 11.5-13 mm long $\times 7.8-10 \mathrm{~mm}$ diam., included 1/3 of their total length in the cupule (Figures $6 \mathrm{E}$ and $8 \mathrm{G}$ ).

Distribution and ecology. Endemic to eastern Mexico, in the Sierra Madre Oriental, in the states of Hidalgo, Oaxaca, Puebla, San Luis Potosi, Tamaulipas and Veracruz. In Hidalgo state it occurs in cloud forests and moist oak forests. Associated with Alnus sp., Clethra sp., Liquidambar sp., Pinus sp., Quercus castanea, Q. laeta and Q. sebifera; at elevations from 1,230 to 1,765 m. Flowering in February; fruits mature in September and November.

Taxonomic comments. $Q$. sartorii is often confused with $Q$. meavei and $Q$. paxtalensis mainly in the vegetative state; however it can be distinguished by its barely shiny leaves with scarcely marked teeth and the hemispheric to obconic cupule, the fruits are annual; $Q$. paxtalensis (also with annual fruits) has a shiny blade, larger teeth and a turbinate and larger cupule. Q. meavei has biennial fruits, wider leaves, larger teeth and a greater number of secondary veins in comparison with the other two species.

Quercus sebifera Trel., Mem. Natl. Acad. Sci. 20: 93. pl. 149. 1924. Type. Mexico: Chiapas. Comitán: Cook 79. Alt. 1620 m, 6 jun 1906 (holotype: US!).

=Q. schenckiana Trel. Quercus ceripes Trel. Quercus chuhuichupensis C. H. Mull. Quercus sebifera f. comitanensis Trel.

Shrubs 10-30 (60) cm tall or small trees 1.5-2 (3) m tall; twigs 1-2.5 mm in diam., gray, slightly furrowed, glabrous or scarcely puberulent with stellate trichomes, lenticels inconspicuous; buds globose to ovoid 1-2.6 mm long, scales broadly ovate, glabrous, slightly shiny, reddish to black-brown, margin shortly ciliate; stipules persistent, long-lanceolate to long-oblanceolate, 2.4-4 mm long. Mature leaves with petioles 1.9-3 (5) × 1.1-2.4 mm, glabrescent, with scarce and scattered acicular trichomes and stellate trichomes; blades coriaceous, obovate, oblong, elliptic or oblanceolate, (2.4) 3.5-7 (9.3) × (1) 1.4-3.5 (4.5) cm, 1.4-2.7 times longer than wide; base rounded or cordate; margin thickened, entire or with 1-5 mucronate short teeth or lobes on each side, located in the distal half of the blade; apex obtuse or rounded, tip mucronate or not; secondary veins 7-11 on each side of the midvein, ascending and moderately curved, branching and anastomosing near the margin; adaxial blade surface glabrous, dull, sometimes with scarce and scattered stellate trichomes towards the base of the midvein; midvein and veinlets flat or barely prominent, secondary veins flat or slightly impressed; abaxial blade surface glabrous, epidermis whitish-papillose, slightly or markedly waxy, veins and veinlets prominent, sometimes yellowish. Fruits annual, 1-3 on a glabrous peduncle 1-2 cm long; cupules hemispheric (0.7) 10-12 mm diam. $\times 4-7 \mathrm{~mm}$ tall, margin erect, scales thickened basally, closely appressed, ovate or deltoid, pubescent; acorns ovoid, 9-15 $\mathrm{mm}$ long $\times 6-9 \mathrm{~mm}$ diam., included $1 / 4$ of their total length in the cupule (Figures $6 \mathrm{~F}$ and $8 \mathrm{H}$ ).

Distribution and ecology. Endemic to Mexico, in the Sierra Madre Oriental and mountains of Chiapas; in the states of Chiapas, Hidalgo, Nuevo Leon, Oaxaca, Puebla, San Luis Potosi, Tamaulipas and Veracruz. In Hidalgo state it occurs in oak forests and pine forests. Associated with Juniperus sp., Pinus sp., Quercus mexicana and Roldana sp.; at elevations from 1,730 to 2,513 $\mathrm{m}$. Flowering time for Hidalgo state is unknown; fruits mature in November.

Taxonomic comments. In Hidalgo state this species has been observed as both shrubs and small trees, 1.5-2 (3) $\mathrm{m}$ tall; the trees are rare and have sprouts growing from the roots. In Hidalgo it is known as Carrasco oak. It can be confused with the shrub species Quercus tinkhamii and $Q$. opaca, but it can be distinguished by its leaves which are waxy abaxially. (See taxonomic comments under $Q$. tinkhamii).

Quercus tinkhamii C. H. Mull. American Midland Naturalist 27: 481. 1942. Type: Mexico. Nuevo León, near Doctor Arroyo, F. Shreve and E. R. Tinkham 9686, 25-Aug- 1940 (holotype: AA). 
Shrubs 15-70 cm tall; twigs (1) 1.5-2.5 mm in diam., slightly furrowed, greyish, tomentose to glabrescent, with stellate trichomes, the rays crispate; buds 1-2 mm long, globose to ovoid, scales ovate, brown or amber, slightly pubescent, margin ciliate; stipules filiform 2-3 mm long. Mature leaves with petioles (2) 3.5-4.6 $\times 0.8-1.2 \mathrm{~mm}$, puberulent, with fasciculate sessile trichomes; blades coriaceous or subcoriaceous, obovate, oblanceolate, elliptic or oblong, 2.5-4.2 $\times 1.3-2.7 \mathrm{~cm}, 1.9-2.5$ times longer than wider; base subcordate or subtruncate, rounded, rarely acute; margin thickened, broadly crispate, entire or with 2-5 mucronate-acute teeth or lobes on each side, located in the distal half or $3 / 4$ of the blade; apex obtuse to rounded; secondary veins (5) 6-9 on each side of the midvein, ascending, straight or the upper moderately curved, continuing directly into the tooth and until the mucro if present, otherwise branching and anastomosing near the margin, evanescent intermediate can also be present; adaxial blade surface shiny, glabrous or glabrate with scarce stellate trichomes towards the base of the midvein; primary and secondary veins flat or slightly promient; abaxial blade surface with scattered or crowded stellate trichomes, intermixed or not with hyaline glandular trichomes, epidermis slightly papillose, veins and veinlets slightly prominent. Fruits annual, 1-2 sessile or on a glabrescent peduncle ca. $5 \mathrm{~mm}$ long; cupules hemispheric to slightly patelliform, 12-14 mm diam. $\times 4-6 \mathrm{~mm}$ tall, scales deltoid, canescent, prominently tuberculate; acorns ovoid, broadly ovoid to oblong, 13-16 mm long $\times 9$ $11 \mathrm{~mm}$ diam., included 1/3 to $1 / 4$ of their total length in the cupule (Figure 6G and 8I).

Distribution and ecology. Endemic to Mexico, in the Sierra Madre Oriental and margins of the Mexican Plateau; in the states of Hidalgo, San Luis Potosi, Nuevo Leon and Tamaulipas. Scarce in Hidalgo state, in stony soils, in arid tropical scrub and pine-oak forests; at elevations from 1,760 to 2,400 m. Flowering time for Hidalgo state is unknown; fruits mature in September and October.

Taxonomic comments. Quercus tinkhamii can be confused with $Q$. sebifera and $Q$. grisea, but its scarcely tomentose leaves, not waxy beneath and its prominently mucronate teeth distinguish it from $Q$. sebifera which has leaves waxy-glaucous on the abaxial blade surface, the margin only has shortly mucronate teeth. Q. grisea has stellate trichomes in two sizes on the abaxial leaf surface and is a tree rather than a shrub; Q. tinkhamii has stellate trichomes only of one size and a shrubby habit.

Quercus trinitatis Trel., Mem. Natl. Acad. Sci. 20:143, pl. 277. 1924. Type: [Mexico], Hidalgo, Trinidad, Pringle 8888 (isotypes: MEXU!, BH!).

Trees 10-30 m tall; twigs 1.4-2.8 mm in diam., terete, glabrous or glabrescent, brown, lenticels pale, raised and conspicuous; buds ovoid to globose, 2.5-3 mm long, scales brown, ovate to broadly ovate, glabrous, margin fimbriate; stipules deciduous. Mature leaves with petioles 9-24 (33) $\times$ 1.2-2.0 mm, glabrous; blades coriaceous, lanceolate, sometimes oblong or elliptic, occasionally asymmetric and curving towards the apex, 7-18 × 2-6.7 cm, (2.4) 3-3.3 (4.4) times longer than wider; base rounded, cuneate or cuneate-decurrent; margin entire and crispate, thick; apex acute or acuminate, tip aristate; secondary veins 9-12 (16) on each side of the midvein, ascending, curved, branching and anastomosing before the margin; adaxial blade surface somewhat shining or dull, glabrous, primary, secondary veins and veinlets barely prominent; abaxial blade surface glabrous or glabrate with tufts of fasciculate stipitate trichomes in the axils of the secondary veins, epidermis slightly papillose, midvein, secondary veins and veinlets moderately prominent. Fruits biennial, 1-2 on a glabrous peduncle 7-20 mm long; cupules hemispheric, 14$18 \mathrm{~mm}$ diam. $\times 8.8-9 \mathrm{~mm}$ tall, margin erect, scales smooth and closely appressed; acorns ovoid, glabrous, $17-21 \mathrm{~mm}$ long $\times 12.4-17 \mathrm{~mm}$ diam., included $1 / 3$ to $1 / 4$ of their total length in the cupule (Figure $6 \mathrm{H}$ ).

Distribution and ecology. Represented by scarce populations in the Sierra Madre Oriental, Sierra Norte of Oaxaca and mountains of Chiapas; in the states of Chiapas, Hidalgo, Oaxaca, Puebla and Veracruz; reaching El Salvador. In Hidalgo state it occurs in cloud forests, pine-oak forests and moist oak forests; at elevations from $(1,490) 1,800$ to 2,250 m. Flowering time for Hidalgo state is unknown; fruits mature from September to November. 
Taxonomic comments. Quercus trinitatis is similar to Q. laurina, Q. affinis and Q. delgadoana, all with biennial fruits. It can be distinguished from the first by its flat cupule scales and the lack of glandular trichomes on the abaxial blade surface (which are present in $Q$. laurina which has the scales thickened basally). Q. trinitatis can be distinguished from $Q$. affinis by its entire blade margin and 9-16 secondary veins on each side of midvein; $Q$. affinis has the blade margin with 1-3 aristate teeth toward the apex and 5-9 secondary veins on each side, while $Q$. delgadoana has 9-20 adaxially impressed secondary veins on each side of midvein and a revolute margin. Quercus trinitatis was trated as Q. ocoteifolia Liebm. by Valencia-A. (2004), however after reviewing the types and the protologues we decided that it is a different species, whose correct name is $Q$.trinitatis. Q. ocoteifolia is not present in Hidalgo state.

Quercus xylina Sheidw. Hort. Belge 4:321. 1837. pl. 18. Type: Mexico. Guadalajara. Cordillera, nov-1840, Galeotti 119 (Holotype: BR!).

$=$ Quercus callosa M. Martens ex A. DC. Quercus laxa Liebm. Quercus reticulata var. laxa (Liebm.) Wenz.

Trees (3) 6-10 m tall; twigs (2.4) 3-4.4 $\mathrm{mm}$ in diam., pubescent becoming glabrescent, indument slightly pale to yellowish, with stellate trichomes, fasciculate sessile trichomes and acicular unicellular trichomes scattered on the twigs, lenticels conspicuous or inconspicuous at first, visible in the second year; buds globose, ovoid, rarely conic, 2-3.3 mm long, scales ovate to broadly ovate, glabrous towards the base, apex tomentose and margin ciliate, amber; stipules deciduous or persistent on the apical buds, then linear to lanceolate 5-10 $\mathrm{mm}$ long, strigose. Mature leaves with petioles (3) 7-13.5 $\times 1-1.8 \mathrm{~mm}$, pubescent to tomentose, with trichomes like those of the twigs; blade coriaceous, oblong or obovate, (5.5) $8.5-14 \times(2.8) 3.5-4.5(7.5) \mathrm{cm}$, 1.7-2.2 (2.8) times longer than wider; base cordate, subcordate or rounded; margin crispate and slightly revolute, crenate or with (2) 3-6 mucronate teeth on each side of the blade located on the distal half of the blade; apex obtuse to rounded; secondary veins 8-11 on each side of the midvein, ascending, straight or moderately curved, branching and anastomosing near the margin, otherwise continuing directly into the tooth if present and until the mucro; adaxial blade surface slightly rugose, glabrous or glabrescent, with scarce stellate trichomes and glandular amber or reddish trichomes towards the midvein, primary, secondary veins and veinlets slightly impressed; abaxial blade surface pubescent, with fasciculate sessile trichomes intermixed with amber or hyaline glandular trichomes scattered on the total surface, epidermis white-papillose, veins and veinlets prominent. Fruits annual, 1-8 on a pubescent peduncle 1-10 $\mathrm{cm}$ long; cupules hemispheric, ca. $15 \mathrm{~mm}$ diam. $\times 7-8 \mathrm{~mm}$ tall, margin erect, scales smooth or thickened basally, closely appressed, canescent; acorns ovoid to oblong, glabrous, 15-18 mm long $\times$ (8) $12-15 \mathrm{~mm}$ diam., included ca. $1 / 2$ of their total length in the cupule (Figures $6 \mathrm{I}$ and $8 \mathrm{C}$ ).

Distribution and ecology. Endemic to central and northern Mexico; in the states of Durango, Guanajuato, Hidalgo, Jalisco, Queretaro and Sinaloa. In Hidalgo state it occurs in pine-oak forests, oak forests and arid tropical scrub. Associated with Acacia sp., Agave sp., Buddleja sp., Calliandra grandiflora, Mimosa sp., Quercus affinis, $Q$. crassifolia, $Q$. crassipes, $Q . \times$ dysophylla, Q. eduardi, Q. rugosa and Salvia sp.; at elevations from 1,661 to 2,630 m. Flowering in May; fruits mature in September and October.

Taxonomic comments. Quercus xylina can be confused with Quercus laeta, Q. obtusata and $Q$. rugosa. Nevertheless it can be distinguished by its tomentose twigs, obovate to oblong blades and fruits on peduncle until $10 \mathrm{~cm}$ long. Additionally these are flat and abaxially have fasciculate sessile trichomes and glandular trichomes; $Q$. laeta has sparse fasciculate sessile trichomes and usually lacks amber glandular trichomes on the abaxial blade surface; $Q$. obtusata has subcoriaceous blades, the leaves are wider than in $Q$. xylina and have scarce fasciculate sessile trichomes on the abaxial surface. In $Q$. rugosa the leaves are coriaceous, slightly rigid, concave abaxially and with sharply mucronate teeth.

After the review of the protologous and the digital images of the types of Q.xylina and Q.laxa at http://plants.jstor.org, we recognize these as the same species, nevertheless $Q$. xylina has priority above $Q$. laxa. 
Species excluded. Quercus alpescens Trel. Specimens of this species were not found in the herbaria revised. The type was collected in Kangandó (Parque Nacional Los Mármoles). Digital image of the type in http://plants.jstor.org shows a similarity with $Q$. greggii, which is present in Hidalgo state and described in this study.

Quercus elliptica Née. According to the protologue (Née 1801), the type of Q. elliptica was collected near Ixmiquilpan in state of Hidalgo, but the species was not found at the type locality, or in herbaria revised (for Hidalgo state). Its distribution in Ixmiquilpan is doubtful. Perhaps there was some confusion with the locality for Née's specimen collected in 1789.

Quercus pachucana Zav.-Chav. This was described from specimens collected near Pachuca, but it was not found in the type-locality, in other localities or in the herbaria revised. The type appears to be a hybrid between $Q$. mexicana and $Q$. laurina since it has trichomes on the abaxial blade surface with a punctate appearance, and the angle of the secondary veins arising of the midvein is as in Q. mexicana, but the aristate teeth towards the apex of the leaves are as those in Q. laurina.

Quercus toxicodendrifolia Trel. This was described from Zacualtipan, Hidalgo in 1924. However in that locality we only found $Q$. affinis, $Q$. crassifolia, and $Q$. lancifolia. The type of $Q$. toxicodendrifolia recalls $Q$. lancifolia and it could represent of relatively broad/leaved form of that species.

\section{Conclusions}

We found for Hidalgo state one species of Fagus and 43 of Quercus, 22 of which belong to section Quercus (white oaks) and 21 to section Lobatae (red oaks). Hidalgo is recognized as a state with a high diversity of Fagaceae. The 44 species found there represent just over a quarter of the oaks in Mexico putting it in fifth place in terms of oaks diversity, after Oaxaca (50 oak species), Puebla (50), San Luis Potosí (45), and Jalisco (45). The species of Fagaceae in Hidalgo state can be identified using the morphological characters presented here.

\section{Acknowledgments}

We thank the Curators of the herbaria FCME, INEGI, MEXU, ENCB, SLPM, HUAP, HUMO, $\mathrm{XAL}$ and $\mathrm{BH}$ for the facilities for the study of herbarium specimens of family Fagaceae. Ma. Fernanda Arévalo Espejel, Patricia Díaz Villamar, Alma C. López C., and Cesar A. García Jaramillo made the illustrations. Sadan Morales Saldaña made the map of Figure 1. We also thank Allen Coombes, Ramiro Cruz Durán and Ariadna Ibarra for their valuable comments to improve this article, Antonio Hernández for capturing the digital illustrations, and the Comisión Nacional para el Conocimiento y Uso de la Biodiversidad (CONABIO) for the economic support granted through JF136 project for the collection of botanical specimens of Fagaceae in Hidalgo state.

\section{Literature cited}

Aldrich PR, Cavender-Bares J. 2011. Quercus. In: Kole C. Ed. Wild Crop Relatives: Genomic and Breeding Resources, Forest Trees, pp. 89-129, Springer-Verlag Berlin Heidelberg. DOI 10.1007/978-3-64221250-5_6

Álvarez-Zúñiga EA, Sánchez-González A, Valencia-Avalos S. 2010. Los encinos del Parque Nacional Los Mármoles, Hidalgo, Mexico. Madera y bosques 16: 55-66.

Berendsohn WG, Gruber AK, Monterrosa SJ. 2009. Nova silva cuscatlanica. Árboles nativos e introducidos de El Salvador. Parte 1: Angiospermae-Familias A a L. Englera 29: 1-438.

Bentham G. 1940. Plantas Hartwegianas imprimis Mexicanas. E. Societate Linnaeana Londinensi. London. DOI: 10.5962/bhl.title.437

Bonpland AJA. 1809. Voyage de Humboldt et Bonpland. In: Humboldt A. von, Bonpland A, Poiteau A, Schiell F, Turpin PJF. Eds. Plantes Équinoxiales. 2. Paris : F. Schoell.

Govaerts R., Frodin DG. 1998. World Checklist and Bibliography of Fagales (Betulaceae, Corylaceae, FAgaceae and Ticodendraceae). Royal Botanical Gardens, Kew. 465 pp.

INEGI. 1992. Sintésis Geográfica del Estado de Hidalgo. México. INEGI. 134. INEGI. 2014. Anuario estadístico y geográfico de Hidalgo. <www.inegi.org.m x> (accessed October, 17, 2016). 
Judd WS., Campbell CS, Kellog EA, Stevens PF, Donoghue MJ. 2002. Plant Systematics a phylogenetic approach. USA: Sinauer Associates, Inc.

Linares JL. 2003 Listado comentado de los árboles nativos y cultivados en la República de El Salvador. Ceiba 44: 105-268.

Little EL. 1965. Mexican Beech, a Variety of Fagus grandifolia. Castanea. 30: 167-170.

Manos PS, Cannon CH, Oh S-H. 2008. Phylogenetic relationships and taxonomic status of the paloendemic Fagaceae of western north America: recognition of a new genus, Notholithocarpus. Madroño 55 : 181-190. DOI: 10.3120/0024-9637-55.3.181

Manos SP, Doyle JJ, Nixon KC. 1999. Phylogeny, Biogeography and processes of molecular differentiation in Quercus subgenus Quercus (Fagaceae). Molecular Phylogenetics and Evolution 12: 333-349. DOI: $10.1006 / \mathrm{mpev} .1999 .0614$

Martínez M. 1940. Una nueva especie forestal (Fagus mexicana sp. nova). Anales del Instituto de Biología 11: 85-89.

Martínez-Morales MA, Ortiz-Pulido R, De la Barreda B, Suri IL, Bravo-Cadena J, Valencia-Herverth J. 2007. HIDALGO. In: Ortíz-Pulido R, Navarro-Sigüenza A, Gómez de Silva H, Rojas-Soto O, Peterson TA. Eds. Avifaunas Estatales de Mexico. Pachuca, Hidalgo, Mexico: CIPAMEX.

McNeill J, Barrie FR, Buck WR, Demoulin V, Greuter W, Hawksworth DL, Herendeen PS, Knapp S, Marhold K, Prado J, Prud`Homme Van Reine WF, Smith GF, Wiersema JH. Eds. 2012. International Code of Nomenclature for algae, fungi and plants (Melbourne Code). Koeltz Scientific Books. <http://www. iapt-taxon.org/nomen/main.php?page=glo> (accessed September 7, 2016).

Muller CH. 1942. The Central American species of Quercus. Miscellaneous Publication: Forest Service: Washington, D.C.: Department of Agriculture No. 477, 216 pp. DOI: 10.5962/bhl.title.65496

Muller CH. 1997. Fagaceae Dum. Beech-Oak. Chestnut Family. In: Henrickson J, Johnston MC, eds. A Flora of The Chihuahuan Desert Region. Edition 1.2, Vol. 1. Los Angeles California, USA. 129-156 pag.

Muller CH, McVaugh R. 1972. The oaks (Quercus) described by Née (1801), and by Humboldt et Bonpland (1809), with comments on related species. Contributions from the University of Michigan Herbarium 9: 507-522.

Murray AE. 1983. Notae spermatophytae no. 2. Kalmia 13: 2-11.

Née L. 1801. Descripciones de varias e species nuevas de encinos (Quercus de Linneo). Annales de Ciencias Naturales 3: 260-278.

Nixon KC. 1993. The genus Quercus in Mexico. In: Ramamoorthy TP, Bye R, Lot A, Fa J. eds. Biological Diversity of Mexico: Origins and Distribution. Nueva York: Oxford University Press, pp: 447-458.

Nixon KC. 1997a. Fagus. In: Flora of North America Editorial Committee, eds. 1993. Flora of North America North of Mexico. Vol. 3. Magnoliophyta: Magnoliidae and Hamamelidae. New York: Oxford University Press.

Nixon KC. 1997b. Quercus. In: Flora of North America Editorial Committee, eds. 1993. Flora of North America North of Mexico. Vol. 3. Magnoliophyta: Magnoliidae and Hamamelidae. New York, Oxford University Press.

Nixon KC, Crepet WL. 1989. Trigonobalanus (Fagaceae): taxonomic status and phylogenetic relationships. American Journal of Botany 76: 828-841.

Nixon KC, Muller CH. 1997. Quercus Linnaeus sect. Quercus. In: Flora of North America Editorial Committee, eds. 1993. Flora of North America North of Mexico. Vol. 3. Magnoliophyta: Magnoliidae and Hamamelidae. New York: Oxford University Press.

Rodríguez-Ramírez ECh, Sánchez-González A, Ángeles-Pérez G. 2013. Current distribution and coverage of Mexican beech forests Fagus grandifolia subsp. mexicana in Mexico. Endangered Species Research 20: 205-216. DOI: $10.3354 /$ esr00498.

Scheidweiler M. 1837. Chênes de Mexique. L'Horticulteur Belge, journal des jardiniers et amateurs 4: 321.

Tovar-Sánchez E, Oyama K. 2004. Natural Hybridization and hybrid zones between Quercus crassifolia and Quercus crassipes (Fagaceae) in Mexico: morphological and molecular evidence. American Journal of Botany 91: 1352-1363. DOI: 10.3732/ajb.91.9.1352

Trelease W. 1924. The American Oaks. Memoirs of the National Academy of Sciences 20: 1-255.

Valencia AS, Flores-Franco G. 2006. Catálogo de autoridad taxonómica del género Quercus, Fagaceae en México. Ciudad de México: Facultad de Ciencias, UNAM. Base de Datos SNIB-CONABIO proyecto CS008.

Valencia-A. S. 2004. Diversidad del género Quercus (Fagaceae) en México. Boletín de la Sociedad Botánica de México 75: 33-53.

Valencia-A. S, Gual-Díaz M. 2014. La familia Fagaceae en el bosque mesófilo de montaña de México. Botanical Sciences 92: 193-204. DOI: 10.17129/botsci.45

Valencia-A. S, Cartujano-P. SL. 2002. Quercus pinnativenulosa (Fagaceae), un encino poco conocido de la Sierra Madre Oriental. Anales del Instituto de Biología 73: 89-94. 
Valencia AS, Nixon KC, Kelly LM. 2011. Quercus delgadoana (Fagaceae), a new species from the Sierra Madre Oriental, Mexico. Novon 21: 274-277. DOI: 10.3417/2009054

Valencia-A. S, Sabas RJL, Soto AOJ. 2016. A new species of Quercus, section Lobatae (Fagaceae) from the Sierra Madre Oriental, Mexico. Phytotaxa 269: 120-126.

Vázquez ML, Valencia AS, Nixon KC. 2004. Notes on red oaks (Quercus Sect. Lobatae) in Eastern Mexico, with description of a new species, Quercus hirtifolia. Brittonia 56: 136-142.

Villaseñor RJL. 2016. Checklist of the native vascular plants of Mexico. Revista Mexicana de Biodiversidad 87: 559-902.

Williams-Linera G, Rowden A, Newton AC. 2003. Distribution and stand characteristics of relicto populations of Mexican beech (Fagus grandifolia var. mexicana). Biological Conservation 109: 27-36.

Zavala-Chávez F. 1995. Encinos hidalguenses. Chapingo, Estado de México: Universidad Autónoma Chapingo. División de Ciencias Forestales.

Zavala-Chávez F. 2000. Quercus pachucana. International Oaks Journal of the International Oak Society 10: 31 . 
Appendix 1. Specimens examined. In bold characters are the species names and the municipality where each specimen was collected.

Fagus grandifolia subsp. mexicana (Martínez) A. E. Murray. San Bartolo Tutotepec: Mountain above San Bartolo Tutotepec, $18 \mathrm{~km} \mathrm{~N}$ of the town, Y. T. Soejima, et al. 2052 (MEXU); on north slope below Tototepec $A$. I Sharp 46169, 46170, 46171, 45859 (MEXU); Tutotepec, F. Miranda 3748 (MEXU); aproximadamente $3 \mathrm{~km}$ al SO de Tutotepec, S Valencia A. \& G. Fores F. 5306, 5310 (FCME). Zacualtipán de Ángeles: Paraje El Hayal, ejido la Mojonera, al sureste del municipio de Zacualtipán, 」 López G. 110 (MEXU); Montes de Zacatlamaya, M. Martínez 1800, 1941 (MEXU); Zacualtipán, M. Martínez 1650 (MEXU); F. Miranda 3243 (MEXU); steep slope at Mojonera near Zacualtipán, A. J Sharp 46227, 46229 (MEXU); ejido La Mojonera, ca. 1 km E of La Mojonera, below and north of the rd La Mojonera-Tlahulompa, $R$. McCauley \& A. Cortés P. 356 (MEXU); 1 $\mathrm{km}$ al E de la desviación a Tlahuelompa, $S$ Valencia $A$. et al. 3740 (FCME). $8 \mathrm{~km}$ al $\mathrm{N}$ del centro de Tlahuelompa, A. Monroy C. \& S Valencia A. 90 (FCME); 1 km al N de Tizapala sobre la carr. A Tlahuelompa, Y. García M. 332 (FCME).

Quercus acherdophylla Trel. Acaxochitlán: Acaxochitlán, M. Martínez 560 (MEXU); Lindavista, sobre el camino a Tenango de Doria, L. Vela G. \& ل Rzedowski 356 (MEXU); Zacacuautla, ca. 7 km $\mathrm{N}$ of Huchinango-Tulancingo, Hwy along RD. To Honey, Puebla, R. McCauley \& A. Cortés P. 345 (FCME); 1 jn S of money, Puebla, R. McCauley $347 \&$ A. Cortés P. (FCME); camino de Honey a San Pedro, S. Valencia A. et al., 3710 (FCME); 1 km al W del entronque de la carr. Tepepa-Acaxochitlán, G. Fores F. 6472 (FCME); 1 km al SW del límite con Tlaxcala o 2 km al NE de Zacacuautla, hacia Honey, G. Fores F. 6484 (FCME). Agua Blanca de Iturbide: $6 \mathrm{~km}$ al NE de Agua Blanca, rumbo a Huayacocotla, S. Valencia A. \& G. Fores F. 2151 (FCME).

Quercus affinis Scheidw. Acaxochitlán: Santiago Tepepa, L. González Q. 503 (SLPM); camino de Honey a San Pedro, S. Valencia A. et al. 3711, 3712 (FCME); 2 km al N de San Pedro, rumbo a Honey, $S$. Valencia $A$. et al. 3717 (FCME); Zacacuautla, ca. 7 km N of Huachinango-Tulancingo Hwy. Along Rd. to Honey, Puebla, R. McCauley \& A. Cortés P. 344 (FCME); 1 km S of Honey Puebla, Ross McCauley \& A. Cortés $P .350$ (FCME); 3 km al NE de ojo de Agua de las Palomas o 3 km al SW de Tepepa, G. Fores F. 6467 (FCME); 4 km al SW de Chimalapa o 3 km al NE Acaxochitlán, camino a Chimalapa, G. Fores F 647, 6476 (FCME); 1 km de San Mateo, carr. a Honey, 2 km al NE del crucero Acaxochitlán-Tulancingo, G. Fores F 6477, 6478 (FCME); 1 km al SW de límite con Tlaxcala o 2 km al NE de Zacacuautla, hacia Honey, G. Fores F. 6483, 6487 (FCME); 17 Milles W of Huachinango, 1 Mi. E of Acaxochitlán, C. H. Muller 9716 (MEXU). Actopan: Los Barrancos, A. 」 Fortoul V. E14D81 (FCME). Agua Blanca de Iturbide: Cerro de las Cruces, Agua Blanca, L. Vela G. 352, 602 (ENCB); alrededores de Agua Blanca, S. Ochoa G. 811 (ENCB). Cardonal: CieneguiIla, rumbo a Ahuacatlán, S. Rangel 192 (MEXU). Chapulhuacán: El Sabinito, S Cartujano P. 602 (FCME). Cuautepec de Hinojosa: $3 \mathrm{~km}$ al NE de El Encinal, $17 \mathrm{~km}$ al NE de Sta. Ma. Nativitas, G. Fores F. 6461 (FCME). Huasca de Ocampo: 2 km al NE de El Zamba, camino a Huasca de Ocampo, G. Fores F. 6504, 6505, 6506, 6507, 6508 (FCME); San Miguel Regla, F. Miranda 883 (MEXU). Ixmiquilpan: El Manantial, A. 」 Fortoul V. E14C69 (FCME). Jacala de Ledezma: Minas Vejas near km 255 on highway between Zimapán and Jacala, H. E Moore J. 3876 (MEXU). Eloxochitlán: 2 $\mathrm{km}$ al E de Eloxochitlán, A. Monroy C. \& S Valencia A. 31 (FCME): 2 km al N de Juárez, A. Monroy C. \& S. Valencia A. 162, 164 (FCME); San Agustín, Eloxochitlán, A. Monroy C. \& S. Valencia A. 25 (FCME). Lolotla: $30 \mathrm{~km}$ al SO de Tlanchinol, Y. García M. 325; Camino Lolotla a Ixtlahuaco, $S$ Ochoa G. 950 (SLPM); Monte Grande, 」 A. Escutia 22, 23 (FCME); a 0.9 km al N de Zapocoatlán, A. Ponce V. \& O. Alcántara A. 324 (FCME); $6 \mathrm{~km}$ al E de Ixtlahuaco, camino a Calnali, S. Valencia A. \& G. Fores F. 2155 (FCME). Metepec: $7 \mathrm{~km}$ al NE de Metepec camino a Tenango de Doria en el Km 9 en la Planta de Asfalto, S. Valencia A. \& G. Fores F. 2138 (FCME). Metztitlán: 1.5 km al E de Zoquizoquiapan, G. Martínez ل 337 (MEXU); Carpinteros, L. Vela 935 (SLPM); Mezquititlán, $\downarrow$ L. López G. 286 (SLPM). Mineral del Chico: Cerro Partido, Parque Nacional El Chico, $\downarrow$ Rocha 2204 (MEXU); Los Carpinteros, A. 」 Fortoul V. E14D81 (FCME); Al este del Chico, S. Valencia A. 2041, 2447 (FCME); a 3 km al E de El Chico, E Pérez M. 1 (FCME). Mineral del Monte: Real del Monte, E Matuda 18892 (MEXU); Pueblo Nuevo, Real del Monte, A. Mondragón H. 2140 (MEXU). La Misión: Cerro prieto, $3 \mathrm{~km}$ al este de Jagüey, A. Monroy C. \& S. Valencia A. 64, 66 (FCME). Molango de Escamilla: Molango, M. Martínez 568 (MEXU); Malila, $1.2 \mathrm{~km}$ al NE, R. Mayorga S. 151 (FCME); Malila, $1.5 \mathrm{~km}$ al E, R. Mayorga S 293 (FCME); Acuatitlán, $1.4 \mathrm{~km}$ al SE, R. Mayorga S. \& O. Alcántara A., 521 (FCME); Acuatitlán, 0.9 km al E, R. Mayorga S \& O. Alcántara A. 702 (FCME). Nicolás Flores: aprox. $10 \mathrm{~km}$ al W de Nicolás Flores, S. Ochoa G. 1070 (MEXU); Desviación a Bocua, 4 km al S de Dothú, A. Monroy C. \& S. Valencia A. 52, 53 (FCME). Omitlán de Juárez: Santa 
Appendix 1. Continuation.

Elena, al N de Omitlán, A. Monroy C. \& S. Valencia A. 150 (FCME); a 0.3 km de la desviación de la carretera El Chico-Atotonilco, A. Monroy C. \& S Valencia A. 16 (FCME); near Omitlán toward Guerrero and Real del Monte. C. H. Muller 9139, 9140 (MEXU). Pacula: Mixcahuales (junto al camino a Jiliapan), S. Rangel 222 (FCME); $1 \mathrm{~km}$ al N de Milpas Viejas, $28 \mathrm{~km}$ al W de la Estancia, G. Fores F. 6409 (FCME). San Bartolo Tutotepec: El Progreso, M. Roqueiro 99 (FCME); al oeste del poblado "Pie de Monte", rumbo a Tutotepec, S. Valencia A. \& G. Fores F. 5302 (FCME); $1.5 \mathrm{~km}$ al norte de Tutotepec, S. Valencia A. \& G. Fores F 5312 (FCME). Tecozautla: San José del Oro, 5 km al $\mathrm{N}$ de Maguey Verde, A. Monroy C. \& S. Valencia A. 75, 76 (FCME). Tenango de Doria: a 1.75 km en línea recta del centro de la ranchería, H. García M. \& E Guizar N. 12 (MEXU); El Damo, aprox. 2 km al SE de Tenango de Doria, desviación a San Nicolás, I. Luna et al. 897 (FCME); El Damo, 2 km al SE de Tenango de Doria, I. Luna V. et al. 903 (FCME); El Cirio, aprox. $1.2 \mathrm{~km}$ al O de San Nicolás, I. Luna V. et al.1473 (FCME). Tianguistengo: $7 \mathrm{~km}$ al N de Tianguistengo, A. Monroy C. \& S. Valencia A. 117 (FCME). Tlanchinol: $1 \mathrm{~km}$ de la desviación a Huayacocotla, A. Monroy C \& S. Valencia 129 (FCME). Tlahuiltepa: Aguazacatal, J C. Calvillo G. E14D51 (FCME). Xochicoatlán: Coatitlamixtla, $1.3 \mathrm{~km}$ al O, R. Mayorga S. 222 (FCME). Zacualtipán de Ángeles: $4 \mathrm{~km} \mathrm{~S}$ of Zacualtipán, C. H. Muller 9330 (MEXU); F. Miranda 3279 (MEXU); Zacualtipán, M. Martínez 238, 581 (MEXU); desviación a Zacualtipán-Tianguistengo, S Valencia A. s.n. (FCME); Paraje Morelos, M. Martínez 2140 (MEXU); Tepeojo, Zacualtipán, L. Vela G. 974 (MEXU); Alumbres, H. Puig 4565 (ENCB); cerca de Zacualtipán, H. Puig 4821 (ENCB); alrededores de Zacualtipán, L. González Q. 316 (ENCB), S. Ochoa G. 862 (SLPM); 3 km al N de Tuzanapa, L. González Q. 813 (ENCB); Ejido La Mojonera. On east side of La Mojonera, R. McCauley \& A. Cortés P. 358 (FCME); km 2 de la carr. A Tianguistengo, a partir de la carr. principal México-Molango, $\downarrow$ L. Contreras 312 (FCME); La cantera, carr. Zacualtipán-Tianguistengo, E Martínez $A$. 106 (FCME); 2 km al N de Jalapa, $A$. Monroy C. \& S. Valencia A. 113 (FCME); 10 km W Zacualtipán, S. Mora C. 17 (FCME); Zacualtipán, A. Coombes 39 (FCME); $3 \mathrm{~km}$ hacia la desviación a Tlahuelompa, carr. Zacualtipán-Pachuca, $S$ Valencia A. \& G. Hores F. 2170, 2173 (FCME); 2 km al S de Tlahuelompa, en el camino a Tizapán, A. Monroy C. \& S Valencia A. 108 (FCME). Zimapán: hacia la Mina San Miguel, R. Hernández M. 6581 (MEXU); 7 km al N de Maguey Verde, S. Valencia A. 1987 (FCME); La Manzana, A. Monroy C. \& S. Valencia A. 81 (FCME); Encarnación, Cañada de Los Marmoles, L. González Q. 949 (ENCB). Sin municipio: entre Velázco y Exhacienda del Carmen, H. Sánchez M. \& C.S. Chávez $2091 B$ y 2093 (MEXU); Hiloche, M. Martínez 38 (MEXU).

Quercus ariifolia Trel. Cardonal: $7 \mathrm{~km}$ al $\mathrm{S}$ de Santuario Mapethé, A. Monroy C. \& S. Valencia A. 45, 46 (FCME). Cuatepec de Hinojosa: $1 \mathrm{~km}$ al SE de Tezoncualpa, área protegida El Campanario, G. Fores F. 6455 (FCME); 1 km al SE del poblado El Aserradero, carr. Hacia La Cañada, G. Fores F. 6419 (FCME). Eloxochitlán: 2 km al E de Eloxochitlán, A. Monroy C. \& S Valencia A. 28, 29, 30 (FCME); 0.5 km al S de Eloxochitlán, A. Monroy C. \& S. Valencia A. 159 (FCME); desviación a Almoloya, 9 km del camino a Eloxochitlán, A. Monroy C. \& S Valencia A. 158, 160 (FCME). Metztitlán: Norte del predio "Tres Cruces", $\rfloor$ L. López G. S.n. (MEXU); 800 m aguas arriba en relación al a carretera federal Pachuca-Zacualtipán, $\rfloor$ L. López G. 45 (MEXU). Mineral del Chico: 1 km antes de llegar al pueblo de Mineral de El Chico, M. Mora ل 2001 (FCME); Paraje Los Negros, Parque Nacional El Chico, camino a La Peña del Cuervo, F. Medina H. 37 (FCME); Presa Jaramillo, E Pérez M. 5 (FCME); El Chico, S. Valencia A. 2007 (FCME); Parque Nacional El Chico, E Martínez A. 92, 93, 94, 97 (FCME). Mineral del Monte: carr. Mineral del Monte hacia Mineral de El Chico, M. Mora \rfloor 2000, 2005 (FCME). La Misión: Cerro Prieto, $3 \mathrm{~km}$ al E de Jagüey, A. Monroy C. \& S Valencia A. 62, 63 (FCME). Molango de Escamilla: carr. De Molango a Eloxochitlán a Santa María, E Tovar 25 (FCME). Nicolás Flores: Brecha Trancas-Nicolás Flores, a 16 km al NE de Tranchas (Cerro Prieto), P. Tenorio 26 \& R. Hernández (MEXU). Omitlán de Juárez: Omitlán toward Guerrero and Real del Monte, C. H. Muller 9136 (MEXU); Mirador de Omitlán, 0.5 km de la desviación de la carretera, A. Monroy C. \& S. Valencia A. 19, 20, 21 (FCME). Pacula: Pacula, A. Sánchez G. 4022 (FCME). Tecozautla: 2 km al S de Maguey Verde, A. Monroy C. \& S. Valencia A. 68 (FCME). Zimapán: 7 km al norte de Maguey Verde, S. Valencia A. 1988, 1989, 1990 (FCME); 3 km al Sur de Minas Viejas, S. Valencia A. 1994 (FCME); El Túnel, A. 」 Fortoul V. E14C59 (FCME); La Manzana, A. Monroy C. \& S. Valencia A. 90 (FCME).

Quercus candicans Née. Acaxochitlán: $2 \mathrm{~km}$ al N de San Pedro, rumbo a Honey, S Valencia A. et al. 3718 (FCME); Acaxochitlán, M. Martínez 593 (MEXU); Below Trinidad Iron Works, C. G. Pringle 1904 (MEXU). Mezquititlán: 3 km al E de El Rodeo, 」 L. López G. 285 (MEXU); desviación a Carpinteros, 2 km al E de la carr. Zacualtipán-Metzquititlán, I. Méndez L. 31 (MEXU). San Bar- 
Appendix 1. Continuation.

tolo Tutotepec: El Progreso, M. Roqueiro 102 (FCME); aproximadamente $2 \mathrm{~km}$ al N de Tutotepec, S. Valencia A. \& G. Fores F. 5317 (FCME). Singuilucan: 4 km al SW de Los Romero, o a 8 km del entronque de la carr. Tulancingo, G. Fores F 6492 (FCME). Zacualtipán de Ángeles: Paraje La Virgencita, $2.5 \mathrm{~km}$ al E de Los Arcos, Zoquizoquipan, E Guizar 5364 (MEXU).

Quercus castanea Née. Acatlán: $17 \mathrm{~km}$ al norte de Acatlán, hacia Huasca, R. Hernández M. 5289, 5291 (MEXU). Acaxochitlán: $2 \mathrm{~km}$ al N de San Pedro, rumbo a Honey, S Valencia A., et al. 3714, 3715 (FCME). Chapantongo: El Colorado, $2 \mathrm{~km}$ al SE del Capulín (8 km del entronque de la carr. Amealco-Sayula), G. Fores F. 6332, 6334, 6335 (FCME); 5 km del entronque de la carr. Amealco-Sayula, hacia Juchitán-El Capulín, G. Fores F. 6325, 6326, 6327, 6329 (FCME). Eloxochitlán: 2 km al N de Juárez, A. Monroy C. \& S Valencia A. 134, 163 (FCME); San Agustín Eloxochitlán, $A$. Monroy C. \& S. Valencia A. 24, 26, 27 (FCME). Huasca de Ocampo: Paraje El Calvario, A. Mondragón H. 2132 (MEXU); 3 km al SSE de Huasca (camino a Zembo), M. Medina \& M. A. Barrios 3828 (MEXU); 4 km al norte de San Miguel Regla, R. Hernández M. 3504 (MEXU); 5 km al E del poblado de San Miguel Regla, G. Fores F. 5835 \& M. Mora (HUMO); 4 km al S de Huasca de Ocampo, camino a Zambo, G. Fores F. 6500, 6502 (FCME). Huichapan: 4 km al Este de Jonacapa, R. Hernández M. 3837 (MEXU); 13 km al S de Jonacapa, G. Fores F. 6384, 6385, 6390, 6391 (FCME); 3 $\mathrm{km}$ al E de Jonacapa, carr. Huichapan-Ixmiquilpan, G. Fores F. 6364 (FCME). Jacala de Ledezma: Near Jacala, H. S. Gentry 9800, 9802a (MEXU); 9 km al sur de Jacala, A. Monroy C. \& S. Valencia A. 86 (FCME); $11 \mathrm{~km}$ al S de Jacala, M. Mora J 118 (FCME). Lolotla: Monte Grande, $\rfloor$ A. Escutia 35 (FCME). Mineral del Chico: Al Este del Chico, S. Valencia A. 2040 (FCME). Nicolás Flores: Al E de Nicolás Flores (por barrio Cruz de Piedra), S. Rangel 210 (MEXU). Nopala de Villagrán: 2 km al NO de San Sebastián de Juárez (12 km al SE de Maravillas), G. Fores F. 6336, 6338, 6340 (FCME); 2 km al N de La Palma a $10 \mathrm{~km}$ al N de San Lorenzo Nenamicaya, G. Fores F. 6343 (FCME). Omitlán de Juárez: $2 \mathrm{~km}$ al W de La Presa carr. Atotonilco-Pachuca, S. Valencia A. \& G. Fores F. 2182, 2183 (FCME); Comunidad de Los Tapancos, 2 km al sur de Venta Reyes, carr. Atotonilco-Pachuca, S. VaIencia A. \& G. Fores F. 2177 (FCME). Pacula: 6 km al N de Milpas Viejas, 33 km de la Estancia, carr. a Pacula, G. Fores F. 6414 (FCME); 3 km al S de Milpas Viejas o 29 km al N de Puerto La Estancia, G. Fores F. 6377, 6378 (FCME); 7 km al S de Milpas Viejas o $25 \mathrm{~km}$ al N de Puerto La Estancia, G. Fores F. 6380 (FCME); Pacula, E Álvarez Z. 82 (FCME). Singuilucan: 4 km al SW de Los Romero, Pachuca o a 8 km del entronque de la carr. Tulancingo, G. Fores F. 6494 (FCME). Tepeapulco: Sendero II, La Rinconada, I. Nava \& A. Gómez, INGH-99 (FCME). Tepeji del Río de Ocampo: 5 km al norte de Tepeji del Río, R. Hernández M. 6608 (MEXU, XAL); 7 km N Poblado San Luis Taxhmimay, S. Mora C. 116 (FCME); 2 km al SO del entronque San Ignacio Nopala y San José Pidra Gorda, G. Fores F 6274 (FCME); 3 km al SO del entronque San Ignacio Nopala y San José Pidra Gorda, G. Fores F. 6279 (FCME). Tulancingo de Bravo: Paxtepec, 4 km al este de Tulancingo, R. Hernández M. 7419 (MEXU, XAL); $500 \mathrm{~m}$ de la desv. A Mirasoles, autopista Singuilucan, S Valencia A. \& G. Fores F. 2124, 2126 (FCME). Zacualtipán de Ángeles: Tlatoxca, 7 km al SE de Zacualtipán, J Lopez G. 524 (MEXU); 7 km S of Zacualtipán, C. H. Muller 9332 A, B (MEXU). Zimapán: Zimapán to mines of El Monte north of Zimapán, H. E Moore f. 4462 \& C. E Wood f. (MEXU); $2 \mathrm{~km}$ al $\mathrm{N}$ de Maguey Verde, S Valencia A. 1983, (FCME). Sin municipio: Chapulazo, cuenca de Alfajayucan, $M$. Avila H. s.n. (MEXU). Entre Velazco y ex hacienda de El Carmen, H. Sánchez M. \& C. Chávez 2091 (MEXU); 20 km al N de Jacala, R. Gutiérrez B. s.n., 20-ene-1980 (FCME).

Quercus corrugata Hook. Acaxochitlán: $4.4 \mathrm{~km} \mathrm{~W}$ of Huauchinango toward Tulancingo, L. Kelly \& K. C. Nixon 1230 (MEXU); $3.3 \mathrm{~km}$ al NO de Nopala, J L. Contreras 9049, 9052 (FCME). San Bartolo Tutotepec: $2 \mathrm{~km}$ al N de El Freson, S Valencia A. \& G. Fores F. 5288 (FCME); aproximadamente $3.5 \mathrm{~km}$ al NE de El Fresno, S. Valencia A. \& G. Fores F. 5289, 5292 (FCME); aproximadamente $3 \mathrm{~km}$ al suroeste de Tutotepec, S. Valencia A. \& G. Fores F. 5307, 5308, 5309 (FCME). Tenango de Doria: $4.9 \mathrm{~km}$ E of Tenago de Doria along rd. to San Nicolás, $R$. McCauley 355 \& $A$. Cortés P. (FCME). Zacualtipán: Paraje Cumbre de Muridores, ejido $2 \mathrm{~km}$ al NE de Zacualtipán, $I$. Ramos N. 18 (MEXU).

Quercus crassifolia Bonpl. Acaxochitlán: $2 \mathrm{~km}$ al N de San Pedro, rumbo a Honey, S. Valencia A. et al. 3715 (FCME); San Francisco Tlancostica, A. Villa K. 171 (MEXU); 1 km al W del entronque de la carretera Tepepa-Acaxochitlán, G. Fores F. 6471, 6473 (FCME); 1 km al SW del límite con Tlaxcala, G. Fores F. 6485 (FCME), 1 km de San Mateo, carretera a Honey, 2 km al N del crucero Acaxochitlán-Tulancingo, G. Fores F. 6480 (FCME). Agua Blanca de Iturbide: Paraje Las Ventanas, E Guízar N. 250 (XAL); 6 km al NE de Agua Blanca en los Cubes, carretera hacia Huayacocotla, S. Valencia A. y G. Fores 2149 (FCME); cerro Viejo, J D. Limón 2262 (MEXU); Predio El Tejocote, 
Appendix 1. Continuation.

al Oeste de Agua Blanca de Iturbide a $2 \mathrm{~km}$ aproximadamente en línea recta desde el centro del mencionado poblado, H. García M. y E Guízar N. 100 (MEXU); Paraje Las Ventanas, E Guízar N. s.n. (MEXU); Agua Blanca, $\rfloor$ Gimate L., s.n. (MEXU). Atotonilco el Grande: $2 \mathrm{~km}$ al W de la Presa carr. Atotonilco-Pachuca, S. Valencia A. \& G. Fores F. 2184 (FCME). Cardonal: 3 km al S del Santuario Mapethe, A. Monroy C. \& S. Valencia A. 42 (FCME). Cuautepec de Hinojosa: 2 km al NE de El Aserradero, 4 km SW de San Lorenzo Sayula, G. Fores F. 6429, 6433 (FCME); 1 km al SE de Tezoncualpa, área protegida El Campanario, G. Fores F. 6454 (FCME); 9 km al SE de Santa María Nativitas, G. Fores F. 6457 (FCME); 3 km al NE de El Encinal, 17 km al NE de Sta Ma. Nativitas, G. Fores F. 6466 (FCME); 2 km al SW de San Lorenzo Sayula, 4 km al NE de El Aserradero, G. Fores $F$ 6434 (FCME); 1 km al SE del poblado El Aserradero, carr. Hacia La Cañada, G. Fores F. 6420, 6421 (FCME). Eloxochitlán: San Agustín, A. Monroy C. \& S. Vaelncia A. 23 (FCME). Huasca de Ocampo: $4 \mathrm{~km}$ al N de San Miguel Regla, R. Hernández M. 3503 (MEXU); Ranchería El Zembo, Ma. de los Angeles G. \& L. Caballero S. 3 (MEXU); El Calvario, A. Mondragón, 2242 (MEXU); 5 km al Occidente de Huasca, R. Hernández M. \& Y. Vázquez 3477 (MEXU); San Miguel Regla, F. Miranda 886 (MEXU); Hacienda San Miguel Regla, F. Miranda 4487 (MEXU); 2 km al NE de El Zamba, camino a Huasca de Ocampo, G. Fores F. 6509 (FCME); 4 km al S de Huasca de Ocampo, camino a Zamba, G. Fores F. 6498 (FCME). Jacala de Ledezma: 17 mi. South of Jacala, Wayne E Manning \& M. S. Manning 53632 (MEXU). Metepec: Apulco, M. Martínez 588 (MEXU); 4 km al NW de Apulco, carretera hacia Huayacocotla, S. Valencia A. \& G. Fores 2146 (FCME); 6 km al NE de Agua Blanca en los Cubes, carretera hacia Huayacocotla, S. Valencia A. \& G. Fores F. 2149 (FCME). Mineral del Chico: Camino a El Chico, E Matuda 2631, 25633 (MEXU); S Valencia A. 1970, 1971 (FCME); El Chico, F. Miranda 402 (MEXU); S. Valencia A. 2000 (FCME); al este del poblado de El Chico, S Valencia A. 2046, 2038 (FCME); El Chico, 2 km de la desviación, M. Martínez 2014 (MEXU); 3 km al S de El Chico, M. Medina \& M. A. Barrios 3615 (MEXU); a 3 km al este de El Chico, E Pérez M. 2 (FCME). Mineral del Monte: 1.5 km al SE de Real del Monte, M. Medina C. 2132 (XAL); Mineral del Monte, Cerca de Tezoantla, $\downarrow$ Espinosa 405 (MEXU); 3-4 km SW of Real del Monte toward Pachuca, C. H. Muller 9123 (MEXU); 1.5 km al SE de Real del Monte, M. Medina C., 2132 (MEXU); Cerca de Peñas Cargadas, R. Hernández M. 2400 (MEXU); 5 km al NW de Real del Monte, R. Palacioss.n. (MEXU). Molango de Escamilla: Coatitlamixtla, 2 km al NO, R. Mayorga S. 630 (FCME). Pacula: 7 km al S de Milpas Viejas o 25 km al N de Puerto La Estancia, G. Fores F. 6379 (FCME). Omitlán de Juárez: Omitlán, a $0.3 \mathrm{~km}$ de la desviación de la carretera, A. Monroy C. \& S. Valencia A. 17, 18 (FCME); Santa Elena, al N de Omitlán, A. Monroy C. \& S. Valencia A. 146 (FCME). Singuilucan: 4 km al SW de Los Romero, Pachuca, G. Fores F. 6493 (FCME). Tecozautla: San José del Oro, 5 km al N de Maguey Verde, A. Monroy C. \& S Valencia A. 77, 78 (FCME). Tenango de Doria: $20 \mathrm{~km}$ al oeste de Tenango de Doria, $R$. Hernández M 3440 (XAL); al Norte del poblado de la Cruz, a 1.75 km en línea recta del centro de la Ranchería, H.García M. \& E Guízar N. 8 (MEXU); Alrededores de Tenango de Doria, $R$. Hernández M. 3325 a 20 km al Oeste de Tenango de Doria, $R$. Hernández M. 3440 (MEXU); Cerro Viejo, $\rfloor$ D. Limón 2263 (MEXU). Tulancingo de Bravo: $500 \mathrm{~m}$ de la desv. A Mirasoles, autopista Singuilucan-Tulancingo, S. Valencia A. \& G. Fores F. 2124, 2126 (FCME). Zacualtipán de Ángeles: paraje La Virgen, $4 \mathrm{~km}$ al NE de la población de Tlahuelompa, $\downarrow$ L. López G. 307 (XAL); Entrada Vivero Municipal por Cooperación a Topixco Piedra Blanca, I. García G. et al. 12 (MEXU); Ejido Zacualtipán, AI SE de la Cabecera Municipal, J L. López G. 205, 250 (MEXU, XAL); Zacualtipán, F. Miranda, 3275 (MEXU); H. Puig 2106 (MEXU); M. Martínez 579 (MEXU); Zacualtipán, Paraje La Virgencita, $2.5 \mathrm{~km}$ al E de los Arcos, Zoquizoquiapan, E Guízar et al. 5340 (MEXU); $3 \mathrm{~km}$ al $\mathrm{N}$ de la desviación a Tlahuelompa, A. Monroy C. y $\mathrm{S}$. Valencia A. 101 (FCME); La Cantera, carretera Zacualtipán-Tianguistengo, E Martínez A. 105 (FCME). Zempoala: Cerro de Los Pitos, A. Ventura A., 1639 (MEXU). Zimapán: 2 km al N de Maguey Verde, S. Valencia A. 1982 (FCME); Parque Nacional Los Mármoles, O. J Soto et al. 78 (MEXU); On upper slopes of El Monte on trail from Zimapán to minas of El Monte, H. E Moore \& C. E Wood, 4477 (MEXU); Encarnación to Mt. Cangandhó, H. E Moore, J. \& C. E Wood, s. 4353 (MEXU); La Manzana, A. Monroy C. \& S. Valencia A. 80 (FCME). Sin Municipio: $2 \mathrm{~km} \mathrm{~N}$ of San Vicente, $30 \mathrm{~km} \mathrm{~S}$ of Jacala, C. H. Muller 9470 (MEXU); 7 mi. of Tulancingo toward Huachinango, C. H. Muller 9715 (MEXU); Tezuantla, M. Martínez 566 (MEXU); Cerca de Tezuantla, 」 Espinosa 404 (MEXU); Entre Velasco y Ex-Hacienda del Carmen, H. Sánchez M. \& C. Chávez 2090 (MEXU).

Quercus crassipes Bonpl. Agua Blanca de Iturbide: $6 \mathrm{~km}$ al NE de Agua Blanca en los Cubes, carretera hacia Huayacocotla, S. Valencia A. \& G. Fores F. 2148 (FCME). Cuautepec de Hinojosa: $2 \mathrm{~km}$ al SW de San Lorenzo Sayula, 4 km al NE de El Aserradero, G. Fores F 6439 (FCME); 2 km 
Appendix 1. Continuation.

al SE de El Aserradero, carr. Hacia La Cañada, G. Fores F. 6423, 6424 (FCME); 1 km al NE del poblado La Cañada, G. Fores F 6422 (FCME). Huasca de Ocampo: Cerca de Huasca, A. Coombers 58, 62 (FCME). Nopala de Villagrán: 7 km del entronque de la carr. Jilotepec-Huichapan, hacia Sn Lorenzo Nenamicoya, G. Fores F. 6285, 6287, 6289 (FCME). Omitlán de Juárez: Santa Elena, al N de Omitlán, A. Monroy C. \& S. Valencia A. 144, 147, 151 (FCME). Santiago Tulantepec de Lugo Guerrero: Ejido Altepemila, M. A. García \& L. Caballero 21 (MEXU, XAL). Tulancingo de Bravo: $500 \mathrm{~m}$ de la desviación a Mirasoles, autopista Singuilucan, S. Valencia A. \& G. Fores F. 2122, 2123, 2127 (FCME); Desviación Acayutla, $500 \mathrm{~m}$ al SE de la autopista Sinquilucan, $S$ Valencia $A$. \& G. Hores F. 2129, 2130 (FCME); Paxtepec, 6 km al occidenete de Tulancingo, R. Hernández M. 3287 (MEXU).

Quercus delgadoana S. Valencia, Nixon et L.M. Kelly. Lolotla: a $1.84 \mathrm{~km}$ al S-E de Tenango, $A$. Ponce V. 74. (FCME); a $2.82 \mathrm{~km}$ al SO de Chalma, A. Ponce V. 207. (FCME). Tenango de Doria: Agua Fría, aproximadamente $500 \mathrm{~m}$ al E de El Damo, O. Alcantara A. 1542 (FCME, MEXU); Agua Fría, aprox. $2.5 \mathrm{~km}$ al E de El Damo, O. Alcantara A. 1509, 1517 (FCME); El Damo, aprox. $1 \mathrm{~km}$ al E, camino Tenango de Doria-San Nicolás, O. Alcantara A. \& E Ortiz B. 1140, 1142 (FCME); El Damo, $2 \mathrm{~km}$ al SE de Tenango de Doria, I. Luna V. et al. 912 (FCME); El Cirio, aprox. $1.2 \mathrm{~km}$ al O de San Nicolás, I. Luna V. et al. 1465 (FCME); 6 km NE de Agua Zarca, S Valencia et al. 3722 (FCME, HUAP); ca. $2 \mathrm{~km}$ W of San Nicolás near W side of steep cliff above rd from Tenango de Doria to San Nicolás, R. McCauley \& A. Cortés P. 354 (FCME); 4 km al SW de Tenango de Doria, camino a Metepec, G. Fores F. 6531, 6532 (FCME). San Bartolo Tutotepec: Al oeste del poblado "Pie de monte", rumbo a Tutotepec, S. Valencia A. \& G. Fores F. 5303 (FCME); aproximadamente $3.5 \mathrm{~km}$ al suroeste de Tutotepec, S. Valencia A. \& G. Fores F. 5304 (FCME); aproximadamente $3.5 \mathrm{~km}$ al NE de El Fresno, S Valencia A. \& G. Fores F. 5290, 5291, 5295 (FCME). Tlanchinol: camino a Coatlán, I. Luna V. et al. 793 (FCME); camino Tlanchino-Coatatlán, I. Luna V. et al. 680 (MEXU, FCME)); 688 (FCME); I. Luna V. \& O. Alcantara A. 691 (FCME); 5 km al E de Tlanchinol, I. Luna V. 45 (FCME); camino a Lontla, $7 \mathrm{~km}$ al N de Tlanchinol, O. Alcantara A. \& R. Mayorga S. 3355 (FCME); Km 165 de la carr. Tlanchinol-Tampico, ca. $5 \mathrm{~km}$ al sur de la desviación de Lontla W, S Valencia A. et al. 3747, 3749 (BH, FCME, HUAP). Xochicoatlán: Alrededores de Xochicoatlán, S. Valencia A. 1341, 1342, 1343, 1344, 1345, 1346, 1347, 1348, 1349, 1350, 1351, 1353, 1354, 1355, 1356 (FCME). Zacualtipán de Ángeles: aprox. $1 \mathrm{~km}$ E sobre la desviación a Tlahuelompa, S. Valencia A. et al. 3741 (FCME, HUAP).

Quercus depressa Bonpl. Epazoyucan: Cerro de Las Navajas, S. Valencia A. 1147 (FCME); Cerro de las Navajas, arriba de la mina de pomex, $S$. Valencia $A$., et al. 3733, 3734, 3735 (FCME).

Quercus deserticola Trel. Ajacuba: "Rincón de Juan Alejo", vertiente $\mathrm{N}$ de la sierra del monte alto de Temoaya, ejido de Tulancanco, I. Díaz V. 258, 276, 276A (MEXU); El burro", cerro al S del poblado Ajacuba, vertiente $\mathrm{N}$ de la sierra del monte alto de Temoaya, ejido Ajacuba, I. Díaz V. 912 (MEXU). Alfajayucan: $5 \mathrm{~km}$ al W de Alfajayucan, R. Hernández M. 6477 (MEXU). Atotonilco el Grande: Comunidad de Los Tapancos, $2 \mathrm{~km}$ al $\mathrm{S}$ de Ventas Reyes, carr. Atotonilco-Pachuca, $S$ Valencia A. \& G. Fores F. 2178 (FCME). Cuautepec de Hinojosa: 2 km al SE de san Lorenzo Sayula, carr. A Texoncualapa, G. Fores F. 6449 (FCME). Huasca de Ocampo: a 4 km al S de San Miguel Regla, R. Hernández M. 3508 (MEXU); 4 km al S de Huasca de Ocampo, camino a Zambo, G. Fores F. 6501 (FCME). Tepeapulco: Cerro Tres Peñas, A. Ventura A. 251 (MEXU); Cerro Xihuigo, A. Ventura A. 367 (MEXU); Cerro de Santa Ana, 4 km al ESE de Tepeapulco, Rzedowski 16938 (MEXU); Tepeji del Río de Ocampo: $7 \mathrm{~km}$ al NO de Santiago Tula, carr. Tepeji del Río-Jilotepec, G. Fores F. 6307, 6308, 6309 (FCME); $10 \mathrm{~km}$ al NO de Santiago Tula, 2 km de entronque de carr. Tepeji del Río-Jilotepec, G. Fores F. 6310, 6311, 6312, 6313 (FCME); 2 km al SO del entronque San Ignacio Nopala y San José Piedra Gorda, G. Fores F. 6276 (FCME). Tlanalapa: Cerro de San Simón, A. Ventura A. 213 (MEXU). Zimapán: 3 km al NE de Trancas, hacia Nicolás Flores, R. Hernández M. 5041 (MEXU). Sin municipio: Sierra de los Pitos, cerca de San Pedro Tlauilpan, Rzedowski 17072 (MEXU); Highway connecting San Juan del Río with Ixmiquilpan, 16 mi. E of Huichipan, 7 mi. E of Jonacapa, 12 mi. W of jnxn with Hwy. 85, open basaltic plateau, with arid grasses, Mimosa, $R$. Spellenberg et al. s.n., 8-oct-1985 (MEXU).

Quercus x dysophylla Benth. Cardonal: Santuario de Mapethe, Velasco y Ojeda 133 (MEXU). Cuautepec de Hinojosa: Ejido El Aserradero, G. Hernández \& H. Germán H. 9 (MEXU); cercanías de Hiloche, Martínez 2699 (MEXU); 2 km al SE de El Aserradero, carr. Hacia La Cañada, G. Hores F. 6425, 6426 (FCME). Huasca de Ocampo: 15 km al Sur de Huasca, R. Hernández M. 3622 (MEXU); above Huasca on road from Mineral del Monte to San Miguel Regla, D. E Breedlove 
Appendix 1. Continuation.

69378, 69381, 69382 (MEXU). Omitlán de Juárez: Santa Elena, al N de Omitlán, A. Monroy C. y S Valencia A. 141 (FCME). Santiago Tulantepec de Lugo Guerrero: Ejido Emiliano Zapata, $M$. de los Angeles y L. Caballero S. 19 (XAL). Singuilucan: Las Lajas, D. Bautista P. s.n. 28-ene-2012 (MEXU); $4 \mathrm{~km}$ al SW de Los Romero, Pachuca o a $8 \mathrm{~km}$ del entronque de la carr. Tulancingo, $G$. Fores F. 6490, 6491 (FCME). Tulancingo de Bravo: $10 \mathrm{~km}$ E of Tulancingo, D. E Breedlove 69395 (MEXU); desviación Acayutla, $500 \mathrm{~m}$ al SE de la autopista Singuilucan, S. Valencia A. \& G. Fores $F$ 2131, 2132 (FCME). Zacualtipán de Ángeles: 9 km S of Zacualtipán, C. H. Muller 9334A (MEXU). Sin Municipio: Entre Velasco y Exhacienda del Carmen, H. Sánchez M. y C. Chávez 2095 (MEXU); Cercanías de Hiloche, M. Martínez 2699 (MEXU); Puerto de Piedra, A. Sánchez G. 55, (MEXU); E Álvarez Z. 53 (FCME).

Quercus eduardi Trel. Acatlán: 5 km al N de Acatlán, R. Hernández M. 6327 (MEXU, XAL). Cardonal: Santuario de Mapethe, C. Velasco \& F. Ojeda 56 (MEXU); El Cubo, 3 km al SE de barranca de Tolantongo, R. Cruz Duran 6000 (FCME); Barranca de Tolantongo, F. González M. et al. 10542 (MEXU); cerro Boludo de Tolantongo, $42 \mathrm{~km}$ al noreste de Ixmiquilpan, F. González M., 9598, 9634 (MEXU); 3 km al sur de Santuario Mapethé, A. Monroy C. \& S. Valencia A. 43, 44 (FCME). Chapulhuacán: $1 \mathrm{~km}$ al S de Amolal, sobre la carr. 85, M. Mora ل 133 (FCME). Jacala de Ledezma: Ahuacatán, $21 \mathrm{~km}$ al oeste de Ahuacatlán carr. de Xilitla a Jalpan, $\rfloor ل$ González L. s.n. 4-ago1984. Huasca de Ocampo: 2 km al sur de San Miguel Regla, R. Hernández M. 3468 (MEXU); 4 km al norte de San Miguel Regla, R. Hernández M. 3504 (XAL); Hacienda de San Miguel Regla, F. Miranda 4483 (MEXU); F. Miranda 881, 4433 (MEXU). Mineral del Chico: El Chico, S Valencia A. 2032b, 2039 (FCME). Pacula: Pacula, E Álvarez Z. 50 (MEXU); A. Sánchez G. 4000 (FCME). San Agustín Metzquititlán: $5 \mathrm{~km}$ al E de Metzquititlán, R. Hernández M. 3959 (MEXU); desviación a Carpinteros; 2 km al E de la carr. Zacualtipán-Metzquititlán, I. Méndez L. 33 \& G. Ortíz C. (MEXU); $3 \mathrm{~km}$ al E de El Rodeo, $\rfloor$ L. López G. 298, 300 (XAL); paraje ubicado a $600 \mathrm{~m}$ al este de Arroyo Hondo, 」 L. López G. 517 (XAL); $13 \mathrm{~km}$ al sur de Tlahuelompa, sobre la carr. Federal a Mezquititlán, Y. García M. 339 (FCME). Tulancingo de Bravo: $1 \mathrm{mi}$ W of San Alejo, $7 \mathrm{mi}$ E of Tulancingo toward Huachinango, C. H. Muller 9713, 9714 (MEXU); 4 km al W de Tulancingo, R. Hernández M. 3315 (MEXU); 5 km al N de Tulancingo, S. Valencia A. et al. 3724, 3725, 3729 (FCME). Zacualtipán de Ángeles: Cerca de Zacualtipán, sobre el camino a Mezquititlán-Zacualtipán: L. Vela G. 2518 (SLPM); 9 km al S of Zacualtipán, C. H. Muller 9335, 9336 (MEXU); Barranca de Tuzamapa, L. González Q. 811 (MEXU); Tlatoxca, 7 km al SE de Zacualtipán, 」 L. García 537 (XAL); 7 km al oeste de Zacualtipán, R. Hernández M. 5391 (MEXU); 3 km al N de la desviación a Tlahuelompa, A. Monroy C. \& S. Valencia A. 95, 99, 100, 103 (FCME); La Herradura, 」 C. Calvillo G. F14D62 (FCME). Zimapán: 7 km al SE de Puerto Juárez, G. Fores F. 6396 (FCME); near km 255 on highway between Zimapán and Jacala, E Moore $\boldsymbol{J}$. 3882 (MEXU).

Quercus frutex Trel. Apan: $1 \mathrm{~km}$ al norte de la ex Hacienda de Chimalapa, R. Hernández M. 5739 (MEXU). Cuautepec de Hinojosa: 4 km al este de Cuautepec, R. Hernández M. 4833 (MEXU); 2 km al NE de El Aserradero, 4 km SW de San Lorenzo Sayula, G. Fores F. 6428 (FCME); 9 km al SE de Santa Maria Nativitas, G. Fores F. 6459 (FCME). Huasca de Ocampo: 2 km al S de San Miguel Regla, R. Hernández M. 3467 (MEXU). Jacala de Ledezma: Jacala, 20 km al W de Sácala, R. Fores C. s.n. (FCME). Metepec: 4 km al NW de Apulco, carr, hacia Huayacocotla, S Valencia \& G. Fores 2142 (FCME). Mineral del Chico: Parque Nacional El Chico, S Valencia A. 2014, 3012 (FCME); Parque Nacional El Chico, junto a la presa Jaramillo, E Guízar s.n. 17-oct-1997 (MEXU); Ejido El Cerezo, camino a Presa El Jaramillo, cerca del Llano Grande, $A$. Loera S. 13 (INEGI); $1 \mathrm{~km}$ al NO de El Cerezo, M. Medina 2900 (FCME); 2 km de la desviación a El Chico, M. Martínez 2105 (MEXU); Valle de Los enamorados, S. Valencia A., 1968 (FCME); Parque Nacional El Chico, E Martínez A. 91 (FCME); ladera este de la presa Jaramillo, A. Monroy C. \& S Valencia A. 8 (FCME). Mineral del Monte: $0.5 \mathrm{~km}$ al N de Pueblo Nuevo, M. Medina y M. A. Barriga 2518 (MEXU); 2 km al WSW de Real de Monte, M. Medina 1569 (MEXU). Singuilucan: Volcán Seco, G. Martínez P. s.n. 23-jun-2001 (FCME). Tepeapulco: Sendero I, 1952’969” y 98²3’635" I. Nava \& A. Gómez 34 (FCME); Tepeapulco, A. Ventura A. 69 (MEXU); Cerro Santa Ana, A. Ventura A. 729 (MEXU); $5 \mathrm{~km}$ al N de la laguna de Tecocomulco, S. Valencia A. 5320 (FCME). Tulancingo de Bravo: Cuyamaloya, cerca de Tulancingo, M. Martínez 2137 (MEXU); Valle de Tulancingo, F. Miranda 4111a (MEXU); 500 m de la desviación a Mirasoles, autopista Singuilucan, S. Valencia A. \& G. Fores F. 2128 (FCME). Zempoala: San Mateo Tlacomulco, A. Ventura A. 3718 (XAL). Zimapán: Zimapán, M. Martínez 79 (MEXU). Sin municipio: Sierra arriba de Pachuca, F. Miranda 4463 (MEXU). 1 km al SE de Cuyamaloyan, F. G. Medrano 10622 (MEXU). Entre Pachuca y Real del Monte, M. Martínez 2765, 2768, 2770 (MEXU). 
Appendix 1. Continuation.

Quercus furfuracea Liebm. Chapulhuacán: M. Mora J 130 (FCME); Pacula: Pacula, E Álvarez Z. 99 (MEXU); La Placita, 33 km al NE de Zimapán, R. Hernández M. 3729 (MEXU); 」 García P. 1080 \& A. Delgado (MEXU). San Bartolo Tutotepec: El Fresno, S Valencia A. \& G. Fores F. 5301 (FCME). Tenango de Doria: $2 \mathrm{~km}$ al SO de Agua Zarca, S. L. Cartujano P. 538 (FCME). Tianguistengo: $7 \mathrm{~km}$ al N de Tianguistengo, A. Monroy C. \& S Valencia A. 116 (FCME). Yahualica: Yahualica, Martínez P. 4 (FCME). Zimapán: Parque Nacional Los Mármoles, E Álvarez Z. 99 (FCME).

Quercus germana Schltdl. et Cham. Calnali: $10 \mathrm{Km}$ al SE de Calnali, S Ochoa G. 969 (MEXU); 9 $\mathrm{km}$ al E de Ixtlahuaco camino a Calnali, S. Valencia A. \& G. Fores F. 2157 (FCME); $19 \mathrm{~km}$ al E de Ixtlahuaco camino a Calnali, S. Valencia A. \& G. Fores F. 2164 (FCME); 1 km de Ahuacatlán, junto a la carretera, E Guízar N. 6618 (FCME). Chapulhuacán: Camino a comunidad de Tamaulipas, H. Hernández G. 96 (FCME); Chapulhuacán, 2 km al NE, O. Alcantara A. \& R. Mayorga S. 3627 (FCME); Chapulhuacán, $2.8 \mathrm{~km}$ al N, al pie del Cerro Los Jarros, O. Alcantara A. \& R. Mayorga $S$ 3785 (FCME); cerro Los Jarros, 3 km al N de Chapulhuacán, O. Alcantara A. \& R. Mayorga S. 3974 (FCME); Chapuluacán, $2.8 \mathrm{~km}$ al N, al pie del Cerro Los Jarros, O. Alcántara A. y R. Mayorga $S$ 3795 (FCME); Chapulhuacán, $2.9 \mathrm{~km}$ al N, camino a El Sotano, O. Alcantara A. \& R. Mayorga S. 3200, 3293 (FCME), 3297 (FCME; MEXU); Hwy. 85, 10 mi. S of San Luis Potosi border; R. Spellenberg et al. 8369 (MEXU); km 327 on Hwy between Santa Ana and Chapulhuacán. H. E Moore, $\boldsymbol{J}$. \& C. E Wood, $\boldsymbol{t}$. 3972 (MEXU); $0.5 \mathrm{~km} \mathrm{SW}$ of El Barro, $7 \mathrm{~km}$ SW of Chapulhuacán, $58 \mathrm{~km}$ NE of Jacala; C. H. Muller 9476 (MEXU); 1 mi NE of Puerto del Zopilote, 3 3/4 mi SW of Chapulhuacán; C. H. Muller 9703 (MEXU); Chapulhuacán, Ejido Tenango; s.colector 4-may-11 (MEXU); 1 km al S de Amolal, sobre la carr. 85, M. Mora J 136 (FCME); camino a la comunidad de Tamaulipas, $H$. Hernández G 96 (FCME); 1 km al S de Amolal, sobre la carr. 85, M. Mora $\rfloor 136$ (FCME). Jacala de Ledezma: near km 327 on highway between Santa Ana and Chapulhuacán, H. E Moore, J. 3972 \& C. E Wood (BH); km 320 on highway between Jacala and Chapulhuacán, H. E Moore, J. 2701 (BH); $11 \mathrm{~km}$ al S de Jacala, M. Mora J 114, 125 (FCME). Lolotla: $30 \mathrm{~km}$ al SO de Tlanchinol, Y. García M. 322 (FCME); a 2 km al NE de Lolotla, A. Ponce V. 182 (FCME); a 2.5 km al E de Lolotla, A. Ponce V. 300 (FCME); Monte Grande, $\rfloor$ A. Escutia 2 (FCME). San Bartolo Tutotepec: 2 km al NE de la entrada de San Bartolo Tutotepec, camino a Huehuetla, G. Hores F. 6523, 6524 (FCME); San Bartolo, F. Miranda 3735 (MEXU). Tenango de Doria: Tenango de Doria, El Texme, $4.5 \mathrm{~km}$ al O de Tenango de Doria, camino entre El Texme y El Zetoy, O. Alcántara A. 1281 (MEXU). Tianguistengo: $7 \mathrm{~km}$ al $\mathrm{N}$ de Tianguistengo, A. Monroy C. \& S. Valencia A. 115 (FCME). Tlanchinol: Tlanchinol, En el poblado de Acatipan; $\downarrow$ l I. Calzada 2505 (MEXU); Camino a Tierra Colorada; I. Luna \& S Ocegueda 330 (MEXU, FCME); Camino a Tierra Colorada; I. Luna \& S. Ocegueda 326 (MEXU); en el poblado de Acatipan; $\boldsymbol{U}$ l. Calzada et al. 2505 (MEXU); aprox. $0.5 \mathrm{~km}$ al N de San Cristobal, hacia la carr. A Ixtlahuaco, S. Valencia A. 3744 (FCME); km 9 de la carretera a Lontla, $6 \mathrm{~km}$ al S de Huayapa, A. Monroy C. \& S. Valencia A. 126, 127, 128 (FCME); aproximadamente $2.8 \mathrm{~km}$ al E de El Damo, I. Luna V. et al. 1429 (FCME); aprox. $0.5 \mathrm{~km}$ al N de San Cristobal, hacia la carr. A. Ixtlahuaco, S. Valencia A. et al. 3744 (FCME). Zacualtipán de Ángeles: Paraje Xocotetitla, orilla del río Coatlacalco, Tlahuelompa, \ Méndez H. et al. s.n. (MEXU); Zacualtipán, Ejido Tlahuelompa, Paraje orilla del camino a San Mateo, Km 3; H. García M. 193 (MEXU). Sin municipio: El Pemoche, S. Cartujano P. 499 (FCME).

Quercus glabrescens Benth. Acaxochitlán: $17 \mathrm{mi} \mathrm{W}$ of Huachinango, $1 \mathrm{mi}$ E of Acaxochitlán, $C$. H. Muller 9717 (BH, MEXU). Agua Blanca de Iturbide: $6 \mathrm{~km}$ al NE de Agua Blanca en los Cubes, carretera hacia Huayacocotla, S Valencia A. y G. Fores F. 2152 (FCME). Cuautepec de Hinojosa: $3 \mathrm{~km}$ al NE de El Encinal, $17 \mathrm{~km}$ al NE de Santa María Nativitas, G. Fores F. 6465 (FCME); 4 km al este de Cuautepec, $R$. Hernández M. 4835 (MEXU). Jacala de Ledezma: Cerro al W de Agua Fría Grande, cerca de Jacala. L. González Q. 904 (XAL). Mineral del Chico: 2 km de la desviación a El Chico, M. Martinez $2108(\mathrm{BH})$; El Chico, C. Pineda \& E Guerrero, s.n. (XAL, MEXU); E Lyonnet 1240 (MEXU); El Chico, La Bruja, 2 km al SSW de El Chico, M. Medina \& M. A. Barrios 3793 (MEXU); El Chico, 3 km al S de El Chico, M. Medina \& H. Cota 3612 (MEXU); Km 12, Parque Nacional El Chico, G. Fores F. 5834 \& M. Mora J (HUMO); E Martínez A. 95 (FCME); M. Mora \} 2 0 0 6 \text { (FCME); } 1 \mathrm { km } \text { antes de llegar al pueblo de Mineral del Chico, M. Mora J2006 (FCME), a } $3 \mathrm{~km}$ al este de El Chico, E Pérez M. 3 (FCME). Mineral del Monte: On Cerro Hiloche at Real del Monte, C. H. Muller 9129 (MEXU). Omitlán de Juárez: Near Omitlan, hacia Guerrero y Real del Monte, Dto. De Pachuca, C. H. Muller 9137, 9138 (BH); Omitlán, a 0.3 km de la desviación de la carretera, A. Monroy C. \& S. Valencia A. 13, 15 (FCME); Omitlan toward Guerrero and Real del Monte, C. H. Muller 9138 (MEXU). San Bartolo Tutotepec: El Progreso, M. Roqueiro 100 (FCME). 
Appendix 1. Continuation.

Tenango de Doria: Tenango de Doria, $\rfloor$ R. Armenta 2078 (BH); M. Martínez 2078 (MEXU); Cerro del Estribo, 」 Limón A. 2078 (MEXU); 15 km al oeste de Tenango de Doria, R. Hernández M. 3439 (MEXU); along road from Metepec, east slope of Cerro del Estribo, D. E Breedlove 69408, 69424, 69439, 69443 (MEXU). Zacualtipán de Ángeles: 4 km al norte de Tlahuelompa, $R$. Hernández M. et al. 6415 (MEXU); 15 km NE of Metepec along to Tenango de Doria, L. Kelly \& K. C. Nixon 1238 (MEXU).

Quercus glaucoides M. Martens et Galeotti. Atotonilco el Grande: Salsipuedes, L. López T. 1526 (FCME). Tecozautla: 2 km al NW de la desv. A Las Rosas, carr. Tecozutla-Tequisquiapan, G. Fores F. 6357 (FCME). Tula de Allende: Cañón de las Adjuntas, Santa María Macúa, L. Romero 4 (MEXU).

Quercus greggii (A. DC.) Trel. Mineral del Chico: camino de El Chico, M. Martínez 2273 (MEXU); Parque Nacional El Chico, N. Cano N. 50 (FCME); 1 km antes de llegar al pueblo de Mineral del Chico, M. Mora J 2003 (FCME). Mineral del Monte: Cerro Hiloche, C. H. Muller 9128 (MEXU); entre Pachuca y Real del Monte, M. Martínez 2826 (MEXU); carr. Mineral del Monte hacia Mineral del Chico, M. Mora J 2004 (FCME). Epazoyucan: Cerro Grande 3 km al S de Epazoyucan, $\rfloor R z e-$ dowski 28327 (MEXU, SLPM); Cerro Grande, 2 km al S de Epazoyucan, I Rzedowski 28955, 28964 (MEXU); 28957 (MEXU, SLPM); 1 km al W de Nopalillo, 」 Rzedowski 37217 (MEXU). Tepeapulco: cerro del Xihuingo, A. Ventura A. 692 (MEXU). Tulancingo de Bravo: Cuyamaloya, M. Martínez 2143 (MEXU). Zempoala: Sierra de los sitos, cerca de San Antonio, J Rzedowski, s.n. (MEXU); cerro Santa María Tecajete, A. Ventura A. 511 (MEXU, SLPM); Cerro de Xihuingo, San Gabriel, A. Ventura A. 561 (MEXU, SLPM).

Quercus grisea Liebm. Agua Blanca de Iturbide: Just befote Apulco, on road from Metepec to Agua Blanca, H. E Moore f. \& C. E Wood t. 4885 (MEXU). Alfajayucan: Alfajayucan, sin colector $A M$ 14, 16 (FCME, MEXU). Chapantongo: ca. $7 \mathrm{~km}$ al SW del entronque de la carr. AmealcoSayula, hacia Rancho Nuevo, G. Fores F 6322 (FCME); 4 km al SO de El Astillero, G. Fores F. 6296 (FCME); ca 8 km al SO del entronque de la carr. Amealco-Sayula, hacia Rancho Nuevo, G. Fores F. 6314, 6315 (FCME). Cuautepec de Hinojosa: 2 km al N de San Lorenzo Sayula, hacia Cuautepec, G. Fores F. 6441, 6442, 6444 (FCME); 2 km al NE de El Aserradero, 4 km SW de San Lorenzo Sayula, G. Fores F. 6427 (FCME). Epazoyucan: Cerro Alto, 3 km al SE de Epazoyucan, J Rzedowski 16895, 32051 (MEXU); 0.5 km al NE de Nopalillo, M. Medina C. 2155 (MEXU). Huichapan: $13 \mathrm{~km}$ al SW de Jonacapa, G. Fores F 6387 (FCME); $1 \mathrm{~km}$ al W del poblado de Jonacapa, carr. Huichapan-Ixmiquilpan, G. Fores F. 6360, 6361 (FCME); 1 km al W de Taxbatha, cerca de la estación de microondas, entronque carr. Huichapan, G. Fores F. 6300, 6301, 6302 (FCME); 3 $\mathrm{km}$ al E del Astillero, camino de terracería a Huichapan, G. Fores F. 6297 (FCME); 10 km al E de Jonacapa, carr. Huichapan-Ixmiquilpan, G. Fores F6365, 6366 (FCME). Nopala de Villagrán: 2 km al norte de La Palma o $10 \mathrm{~km}$ al N de San Lorenzo Nenamicoya, G. Fores F 6342 (FCME); $3 \mathrm{~km}$ al E de Nopala de Villagrán, cerca del poblado El Jaguey, G. Hores F. 6290, 6291, 6292 (FCME). Pacula: Pacula, Parque Nacional Los Mármoles, A. Sánchez G. 4013 (FCME). Tepeapulco: cerro de Xihuingo, A. Ventura A. 371, 724 (MEXU). Tula de Allende: Cañón de las Adjuntas, Santa María Macua, L. Romero 2, 3 (MEXU). Zimapán: El Huacri, $4 \mathrm{~km}$ al SE de Puerto Juárez, G. Fores $F$. 6397 (FCME). Sin municipio: 2 km E of Jonacapa, 17 km E of Huichapan, C. H. Muller 9321, 9322 (MEXU, BH). Between Huichapan and Ixmiquilpan, $1 \mathrm{~km} \mathrm{~W}$ of Jonacapa, D. E Breedlove 69262, 69254 (MEXU, BH).

Quercus hirtifolia Vázquez, Valencia et Nixon. Acaxochitlán: $1 \mathrm{~km}$ al W del entronque de la carr. Tepeapa-Acaxochitlán, G. Fores F. 6470 (FCME). San Bartolo Tutotepec: $1.5 \mathrm{~km}$ al norte de Tutotepec, S Valencia A. \& G. Fores F. 5314, 5315 (FCME); aprox. $3.5 \mathrm{~km}$ al suroeste de Tutotepec, S. Valencia A. \& G. Fores F. 5305 (FCME). Tenango de Doria: Cerro del Estribo, Guardia Forestal 2118 (MEXU); JD. Limón 2019 (MEXU); El Estribo, $11 \mathrm{~km}$ al SO de Tenango de Doria, $O$. Alcantara A. 1718 (FCME); El Potrero, aprox. 4 km al SO de Tenango de Doria, O. Alcantara A. \& E Ortíz 1177, 1761 (FCME); El Texme, $4.5 \mathrm{~km}$ al O de Tenango de Doria, camino entre El Texme y El Zetoy, O. Alcantara A. \& E Ortíz 1287 (FCME); I. Luna V. et al. 1321 (FCME); 25 km al E de Metepec, hacia Tenango de Doria, R. Hernández M. 4734 \& R. Hernández V. (MEXU); ca. 25 km E of Metepec along rd to Tenango de Doria, R. McCauley 351 \& A. Cortés P. (FCME); ca. 21 km E of Metepec along rd to Tenango de Doria, $1 \mathrm{~km} \mathrm{SW}$ of El Estribo, R. McCauley 349 \& A. Cortés $P$. (FCME); 11 km al O de Tenango de Doria, R. Hernández M. 3420 (MEXU); 6 km al NE de Agua Zarca, S. Valencia A. et al. 3720 (FCME); 4 km al E de Agua Zarca, rumbo a Tenango de Doria, $S$ Valencia A. \& G. Fores F. 5319 (FCME).

Quercus laeta Liebm. Chapulhuacán: $1 \mathrm{~km}$ al S de Amolal, sobre la carr. 85, M. Mora ل 131 
Appendix 1. Continuation.

(FCME). Eloxochitlán: 2 km al N de Juárez, A. Moroy C. \& S. Valencia A. 165 (FCME); Gilo, 4 km de Eloxhocitlán, A. Monroy C. \& S Valencia A. 130, 131, 138 (FCME); 9 km al S de Eloxochitlán, A. Monroy C. \& S Valencia A. 22 (FCME). Jacala de Ledezma: entrada al Parque Nacional Los Mármoles, carretera Francisco I. Madero-Jacala, G. Fores F. 5823, 5827 \& M. Mora J (HUMO); 9 km al sur de Jacala, A. Monroy C. \& S. Valencia A., 88 (FCME); O. Alcantara A. \& R. Mayorga S. 3605 (FCME); Laguna Seca, $6 \mathrm{~km}$ al norte de El Pinalito, O. Alcantara A. \& R. Mayorga S 3067, 3068 (FCME). La Misión: La Misión, E Tovar S 41 (FCME); Cuesta Colorada, E Tovar S 44 (FCME). Molango de Escamilla: Alrededores de Chinameca, L. González Q. 1598 (SLPM). Omitlán de Juárez: Santa Elena, al N de Omitlán, A. Monroy C. \& S. Valencia A. 140, 149 (FCME). Pacula: Pacula, $A$. Sánchez G. 4030 (FCME); 6 km al N de Milpas Viejas, 33 km de La Estancia, carr. Pacula, G. Fores F. 6411 (FCME). Tula de Allende: $8 \mathrm{~km}$ al W de la caseta de cobro de Tula, autopista Arco-Norte autopista Mexico-Querétaro, G. Fores F. 6351, 6355 (FCME). Zimapán: 5 km al S de Maguey Verde, S. Valencia A. 1977 (FCME); 2 km al N de Maguey Verde, S Valencia A. 1979, 1980, 1981 (FCME); $3 \mathrm{~km}$ al S de Minas Viejas, S Valencia A. 1992, 1993 (FCME); 1 km al S de Minas Viejas, S. Valencia A. 1997 (FCME); 5 km al NW de Garabatos, camino a Cajay o Planta concentradora, G. Fores F. 6368, 6374 (FCME). Sin municipio: cerro de Santa María, cerca de Lagunilla, 」 Rzedowski, 28070 (SLPM); 2 km N of Metzquititlán on road to Zacualtipán, C. H. Muller $9327(\mathrm{BH})$.

Quercus lancifolia Schltdl. et Cham. Mineral del Chico: Parque Nacional El Chico, S Valencia A. 3316 (FCME). Molango de Escamilla: $7 \mathrm{~km}$ al E de Molango, en la brecha a Jalamelco, S. Valencia A. \& G. Hores F. 2154 (FCME); cercanías de Molango, M. Martínez 208 (FCME). San Bartolo Tutotepec: $1.5 \mathrm{~km}$ al norte de Tutotepec, S. Valencia A. \& G. Fores F. 5313, 5316 (FCME). Tenango de Doria: $6 \mathrm{~km}$ al Oeste de Tenango de Doria, R. Hernández M. 3411 (MEXU, XAL); $6 \mathrm{~km}$ al NE de Agua Zarca, S. Valencia A. et al. 3723 (FCME); 4 km al SW de Tenango de Doria, camino a Metepec, G. Fores F. 6528, 6529 (FCME); 7 km al NE de Metepec, camino a Tango de Doria en el km 9 en la planta de asfalto, S. Valencia A. \& G. Fores F. 2137 (FCME). Tlanchinol: km 165 de la carretera Tlanchinol-Tampico, aprox. $5 \mathrm{~km}$ al S de desv. A Lontla, $S$ Valencia A. et al. 3745 (FCME). Xochicoatlán: Acomulco, Y. García M. 326 (FCME); 9 km sobre el camino de terracería a Jalamelco, Y. García M. 327 (FCME). Zacualtipán de Ángeles: 4 km al norte de Tlahuelompa, R. Hernández M. 6410, 6415 (XAL); 3 km hacia la desviación a Tlahuelompa, carretera Zacualtipán-Pachuca, $S$ Valencia A. \& G. Fores F. 2171, 2174 (FCME); 1 km al norte de la desviación a Tianguistengo, $E$ Pérez M. 9 (FCME); 1 km de la desviación a Tlahuelompa, E Pérez M. 7 (FCME); 8 km al norte del centro de Tlahuelompa, A. Monroy C. \& S. Valencia A. 92 (FCME).

Quercus laurina Bonpl. Acaxochitlán: $1 \mathrm{~km}$ al SW del límite con Tlaxcala, $2 \mathrm{~km}$ al NE de Zacacuautla, hacia Honey, G. Fores F. 6488 (FCME). Cuautepec de Hinojosa: 2 km al SW de San Lorenzo Sayula, 4 km al NE de El Aserradero, G. Fores F. 6437, 6438 (FCME). Epazoyucan: Cerro de Las Navajas, S. Valencia A. 1138, 1139, 1140, 1141, 1142, 1143, 1144, 1145, 1146, 1151, 1152 (FCME). Huasca de Ocampo: San Miguel Regla, F. Miranda 884 (MEXU). Mineral del Chico: Presa Jaramillo, $4.5 \mathrm{~km}$ al N de Pachuca, M. Medina 1066 (MEXU); Presa Jaramillo, Parque Nacional El Chico, F. García D. 80 (ENCB, MEXU); Cerro de Las Ventanas, 6 km al N de Pachuca, Rzedowski 16737 (MEXU); Cerro de Las Ventanas, A. Gentry et al. 32189 (MEXU); El Chico, Las Ventanas, 5.5 km al N de Pachuca, M. Medina C. 2278 (XAL); Parque Nacional El Chico, E Guizar et al. s.n. (MEXU); M. Cházaro B. \& P. Padilla 2005 (MEXU); 」 Rocha C. 2204 (MEXU); Parque Ncional El Chico, E Martínez A. 87, 88, 89, 90, 98,99, 100, 101 (FCME); El Chico, F. Miranda 404 (MEXU); S. Valencia A. 2003, 2008 (FCME); 2 km de la desviación a El Chico, M. Martínez 2107 (MEXU); km 12, Parque Nacional El Chico, G. Fores F. 5833 y M. Mora (HUMO); El Chico, mirador Peña del Cuervo, S Valencia A. 2021, 2054, 2055, 2057. Lolotla: a $3.21 \mathrm{~km}$ al N de Zapocoatlán, $A$. Ponce V. 372 (FCME). Mineral del Monte: Mineral del Monte, Km 377, $0.5 \mathrm{~km}$ de Tezuantla y 3 km al E de Real del Monte, S. Valencia A. 1153, 1155, 1156, 1157 (FCME); cerca de Tezuantla, J Espinosa 416 (MEXU, ENCB); al SSE de Real del Monte, M. Medina 1080 (MEXU); Hiloche, $M$. Martínez 2041 (MEXU). Tepeapulco: Cerro Santa Ana, A. Ventura A. 321 (MEXU); Cerro Xihuingo, A. Ventura A. 1050 (MEXU). Tepehuacán de Guerrero: Otongo, S. Valencia A. 806C (FCME). Sin municipio: cañada El Salto, $5 \mathrm{~km}$ al N de Pachuca, M. Medina 303 (XAL).

Quercus meavei Valencia-A., Sabás et Soto. Calnali: $16 \mathrm{~km}$ de la desviación a Calnali, A. Monroy C. \& S. Valencia A. 122 (FCME). San Bartolo Tutotepec: $2 \mathrm{~km}$ al N de El Fresno, S Valencia $A$. y G. Fores F. 5285b, 5287b (FCME); aproximadamente $2.5 \mathrm{~km}$ al N de El Fresno, $S$. Valencia $A$. \& G. Fores F. 5293 (FCME); aproximadamente $3 \mathrm{~km}$ al NE de El Fresno, S. Valencia A. \& G. Fores F. 5294b, 5296 (FCME); aproximadamente $3 \mathrm{~km}$ al sur de Tutotepec, S. Valencia A. \& G. Fores F. 
Appendix 1. Continuation.

5311 (FCME). Tenango de Doria: Tenango de Doria, R. Hernández 3325 (XAL); El Damo, aproximadamente $2 \mathrm{~km}$ al SE de Tenango de Doria, desviación a San Nicolás, I. Luna V. et al. 845 (FCME, MEXU); El Potrero, aprox. 4 km al SO de Tenango de Doria, I. Luna V. et al. 1346 (FCME); Agua Fría, aproximadamente $500 \mathrm{~m}$ al E de El Damo, I. Luna V. et al. 1455 (FCME); $6 \mathrm{~km}$ al NE de Agua Zarca, S. Valencia A. 3721 (FCME); km 23 de la carr. Tenango de Doria-Agua Zarca, S. Valencia A. 5283 (FCME); East slope of Cerro del Estribo, above Tenango de Doria along road from Metepec, D. Breedlove 69425,69426, 69427, 69449 (MEXU); 8-11 km southwest of Tenango de Doria, $D$. Breedlove 59561 (MEXU); 4.8 km E of Tenango de Doria along rd to San Nicolás, R. McCauley 353 y A. Cortés(MEXU); $9 \mathrm{~km}$ al SW de Tenango de Doria o $1 \mathrm{~km}$ al NE de El Potrero, G. Fores F. 6533 (FCME); km 23 de la carr. Tenango de Doria-Agua Zarca, S. Valencia A. 5283 (FCME). Zacualtipán: Paraje Cumbre de Tlahuelompa, 2 km al SW de Tlahuelompa, López 328 (XAL); paraje La Laja, 1 km del poblado de Tlahuelompa, Verdugo Z8 (XAL).

Quercus mexicana Bonpl. Acaxochitlán: $2 \mathrm{~km}$ al $\mathrm{N}$ de San Pedro, rumbo a Honey, $S$ Valencia A. et al. 3713, 3719 (FCME); 1 km de San Mateo, carr. a Honey, 2 km al N de crucero AcaxochitlánTulancingo, S. Valencia A. 6481 (FCME). Ajacuba: Rincón del Agua, al SE del Poblado de Ajacuba, vertiente $\mathrm{N}$ de la Sierra del Monte Alto de Temoaya, O I. Díaz V. 1272, 1307 (MEXU); W de "La Mesa de la Cruz", cerro al N del poblado de Ajacuba, vertiente $N$ de la Sierra del Monte Alto de Temoaya, I. Díaz V. 1255 (MEXU). Cardonal: 3 km al sur de Santuario Mapethe, A. Monroy C.\& S. Valencia A. 37, 41 (FCME); 7 km al sur de Santuario Mapethe, A. Monroy C. \& S Valencia A., 47 (FCME); Cerro Prieto, 4 km al este de Juagüey, A. Monroy C. \& S. Valencia A. 58, 59, 60 (FCME). Chapantongo: ca. $7 \mathrm{~km}$ al SW del entronque de la carr. Amealco-Sayula, hacia Rancho Nuevo, G. Fores F. 6319, 6320, 6321 (FCME); 4 km al SO de El Astillero, G. Fores F. 6293 (FCME). Chapulhuacán: $1 \mathrm{~km}$ al S de Amolal, sobre la carr. 85. M. Mora ل 128, 135 (FCME). Cuautepec de Hinojosa: 4 km al este de Cuautepec, R. Hernandez M. 4832 (XAL); 2 km al NE de El Aserradero, 4 km SW de San Lorenzo Sayula, G. Fores F. 6431, 6432 (FCME); 2 km al N de San Lorenzo Sayula, hacia Cuautepec, G. Fores F. 6440, 6443 (FCME). Eloxochitlán: Eloxochitlán, H. I. Puig HHP834 (MEXU). Epazoyucan: 4 km al NW de Nopalillo, M. Medina 1560 (XAL). Huasca de Ocampo: 2 km al S de San Miguel Regla, R. Hernández M. 3469 (MEXU). Jacala de Ledezma: Laguna Seca, $6 \mathrm{~km}$ al $\mathrm{N}$ de El Pinalito, O. Alcantara A. 3066, 3069 (FCME); $9 \mathrm{~km}$ al sur de Jacala, A. Monroy C. \& S. Valencia A. 84 (FCME); entrada al Parque Nacional Los Mármoles, carretera Francisco I. Madero-Jacala, G. Fores F. \& M. Mora $\rfloor$ 5825, 5828 (HUMO); 20 km al W de Jacala, R. Robledo S. s.n. 15-jul-1979 (FCME); 5 km al norte de Jacala, R. González Y., s.n. 20-jul-1082 (FCME); 11 km al NW de Jacala, F. Ramírez R. s.n. (10-dic-1977); al S de Jacala, C. Gracia M. s.n. (FCME); 20 $\mathrm{km}$ al oeste de Jacala, R. Fores C. s.n. (FCME); Near Jacala, H. S. Gentry 9799 (MEXU); Maguey Verde, Parque Nacional Los Marmoles, carr. Francisco I. Madero-Jacala, G. Fores F. 5831 (FCME, HUMO); 64 km de Ixmiquilpan, hacia Jacala, L. Campos s.n., 8-II-1985 (FCME); 25 km al sur de Jacala, D. Tagle J.A. s.n., 19-VII-1985 (FCME). La Misión: Cerro Prieto, 4 km al este de Jagüey, $A$. Monroy C. \& S. Valencia A. 58, 59, 60, 61 (FCME); Cerro Prieto, 3 km al este de Jagüey, A. Monroy C. \& S. Valencia A., 65 (FCME); 25 km al sur de Jacala, 」 Díaz T. s.n. 19-jul-1985 (FCME). Metepec: Ferrería de Apulco, on southern edge of village, K. Taylor \& M. Nee 211 (XAL); 4 km al NW de Apulco, carr. hacia Huayacocotla, S. Valencia A. \& G. Fores F. 2141, 2144 (FCME). Mineral del Chico: El Chico, ladera oeste de la presa Jaramillo, A. Monroy C. \& S. Valencia A. 5 (FCME); 1 $\mathrm{km}$ al N de Cerezo, M. Medina 266 (XAL); 14 km al NE de Pachuca, M. A. Ortiz O. s.n. (FCME); El Chico, S. Valencia A. 1969, 2001, 2009, 2011, 2015, 2016 (FCME); 5 km de la entrada de Parque Nacional El Chico, carr. Mexico-Pachuca, A. L. Díaz s.n. (FCME); 14 km al NE de Pachuca, R. Vera A. s.n 12-V-1978 (FCME); alrededor de la Presa Jaramillo, E Pérez M. 4 (FCME); camino a El Chico, S. Valencia A. 1969 (FCME). Mineral del Monte: km 6 Pachuca-Tampico, Pacheco et al. 8 (MEXU); $5 \mathrm{~km}$ al SE de Mineral del Monte, L. Zamora \& P. Barquín 755 (XAL), Mineral del Monte, km 377, 05 km de Tezuantla y 3 km al E de Real del Monte, S. Valencia A., 1154 (FCME). Nopala de Villagrán: aproximadamente $9 \mathrm{~km}$ al SE de las Maravillas, G. Fores F. 6303, 6304, 6306 (FCME). Omitlán de Juárez: 11 km Noreste de Pachuca, M. C. Ortíz \& Pérez, s.n. 13-v-1978 (FCME); Santa Elena, al norte de Omitlán, A. Monroy C. \& S. Valencia A. 151, 152 (FCME). Pachuca de Soto: $11 \mathrm{~km}$ al NE de Pachuca y 8 km SE del Chico, D. Silva S s.n., 13-may-1978 (FCME); E Valdovinos H. s.n. (FCME); P. Arboleyda s.n. 13-V-1978 (FCME); S. Guzmán G. 11, 13-may-1978 (FCME); E Martín C. s.n. 13-may-1978 (FCME); K. Oyama 11 (FCME); M. Cristina O. s.n. 13-may1978 (FCME); 14 km al NE de Pachuca, R. Vera A., s.n., 12-may-1978 (FCME); M. A. Ortíz O., s.n. 12-may-1978 (FCME). Pacula: 3 km al S de Milpas Viejas o 29 km al N de Puerto La Estancia, 
Appendix 1. Continuation.

G. Fores F. 6376 (FCME); 1 km al N de Milpas Viejas, 28 km al W de La Estancia, G. Fores F. 6410 (FCME). San Agustín Mezquititlán: Barranca de Mezquititlán, 9 km al NE de Mesquititlán, F. González M. 7930 (MEXU, XAL). Tecozautla: Maguey Verde, Parque Nacional Los Mármoles, carretera Francisco I. Madero-Jacala, G. Fores F. 5831 \& M. Mora J (HUMO); 2 km al sur de Maguey Verde, A. Monroy C. \& S. Valencia A., 67 (FCME); Maguey Verde, A. Monroy C. \& S. Valencia A. 73 (FCME); San José del oro, $5 \mathrm{~km}$ al norte de Maguey Verde, A. Monroy C. \& S. Valencia A. 79 (FCME). Tenango de Doria: El Estribo, $11 \mathrm{~km}$ al SO de Tenango de Doria, O. Alcantara A. 1725 (FCME); El Estribo, 11 km al SO de Tenango de Doria, O. Alcantara A. 1725 (FCME). Tepeapulco: Sendero II, La Rinconada, I. Nava \& A. Gómez 100 (FCME). Tlahuiltepa: Aguazacatal, J C. CalviIlo C. E14D51 (FCME). Tepeji del Río de Ocampo: $3 \mathrm{~km}$ al SO del entronque San Ignacio Nopala y San José Piedra Gorda, G. Fores F. 6278 (FCME); 1 km al SE de Santa Ana Atzcapotzatlango, entronque de la autopista, México-Querétaro, G. Fores F. 6282, 6283, 6284 (FCME). Tula de Allende: $8 \mathrm{~km}$ al W de la caseta de cobro de Tula, autop. Arco-Norte autopista México-Querétaro, G. Fores F. 6346, 6348 (FCME). Tulancingo de Bravo: $5 \mathrm{~km}$ al N de Tulancingo, S. Valencia A. et al. 3726, 3728 (FCME); $1 \mathrm{~km}$ al NE del Abra, carr. libre Tulancingo-Tuxpan, S. Valencia A. \& G. Fores F. 2133, 2134, 2135 (FCME). Zacualtipán: a $10 \mathrm{~km}$ al SO de Zacualtipán, R. G. Cordero s.n., dic- 1977 (FCME); 3 km hacia la desv. a Tlahuelompa en terracería, carr. Zacualtipán-Pachuca, S. Valencia A. 2172, 2173 (FCME); 5 km al N de Maguey Verde, S. Valencia A. 1975, 1976 (FCME). Zimapán: 10.5 mi up mine rd W of México 85.2 mi N of Posada del Rey, $\downarrow$ A. Mears 321d (MEXU); 17 km al noreste de Zimapán, R. Hernández M. 3713 (XAL); 5 km al N de Maguey Verde, S. Valencia A. 1976, 1976b (FCME); 2 km al N de Maguey Verde, S. Valencia A. 1985 (FCME); 2 km al SE de Puerto Juárez, G. Fores F. 6393, 6394, 6395 (FCME); El Huacri, 4 km al SE de Puerto Juárez, G. Fores F. 6398, 6399, 6400 (FCME); 5 km al NW de Garabatos, camino a Cajay o Planta concentradora, G. Fores F. 6367, 6370, 6373, 6375 (FCME). Zempoala: Tlajomulco, A. Ventura A. 748 (XAL). Sin municipio: Sierra de Los Pitos, cerca de San pedro Tlaquilpan, 」 Rzedoski 17071 (MEXU). 5 km al SW de la Rastreadora (Transmisiones), F. González M. et al. 10648, 10656 (MEXU, XAL). Along Highway 85 between Zimapán and Jacala, $35.5 \mathrm{~km}$ by road NE of Zimapán, $11 \mathrm{~km}$ by road SW of Los Duraznos, G. Diggs W. \& C. Corcoran 2358 (XAL); 64 km de Ixmiquilpan hacia Jacala, L. Campos s.n. 8-feb-1985 (FCME).

Quercus microphylla Née. Ajacuba: ladera E de "La mesa Chata", cerro al NW del poblado Santiago Tezontle, sierra del Mexe, I. Díaz V. et al. 1210 (MEXU).

Quercus obtusata Bonpl. Acatlán: $17 \mathrm{~km}$ al norte de Acatlán, hacia Huasca, R. Hernández M. 5286 (MEXU). Agua Blanca de Iturbide: Cerro de las cruces, cerca de Agua Blanca, L. González Q. 359 (MEXU). Highway connecting San Juan del Rio with Ixmiquilpan, 12 mi. E of Huichipan, 3 mi E of Jonacapa, 16 mi W of jnxn with Highway. 85, R. Spellenberg et al. s.n. (MEXU). Cardonal: camino a las grutas de Tolantongo, a $1 \mathrm{~km}$ del módulo de información, A. Monroy C. \& S. Valencia A. 34 (FCME). Calnali: 17 km al E de Ixtlahuaco, carr. Calnali, S. Valencia A. 2160 (FCME). Huasca de Ocampo: Hacienda San Miguel Regla, F. Miranda 4478, 4484, 4489 (MEXU); Ranchería "El Zembo", M. de los Angeles y L. Caballero S. 5, 7 (MEXU); $15 \mathrm{~km}$ al sur de Huasca, R. Hernández M. 3621 (MEXU). Ixmiquilpan: Santuario, 22 km al NNE de Ixmiquilpan, L. González Q. 2275 (MEXU). La Misión: Los Nogales, E Tovar 46 (FCME). Lolotla: 6 km al NE de Ixtlahuaco, camino a Calnali, S. Valencia A. 2155 (FCME); 17 km al E de Ixtlahuaco, carr. Calnali, S Valencia A. 2159, 2160 (FCME). Mineral del Chico: al este del poblado de El Chico, S Valencia A. 2045 (FCME). Mineral del Monte: Real del Monte, M. Martínez 548 (MEXU). Omitlán de Juárez: near Omitlán, toward Guerrero and Real del Monte, C. H. Muller 9143 (MEXU); Santa Elena, al norte de Omitlán, A. Monroy C. \& S Valencia A. 153 (FCME), $2 \mathrm{~km}$ al W de la presa carretera Atotonilco-Pachuca, $S$ Valencia A. \& G. Fores F. 2181 (FCME) ; comunidad de los Tapancos, 2 km al sur de Venta Reyes, carr. Atotonilco-Pachuca, S. Valencia A. \& G. Fores F. 2180 (FCME). San Agustín Metzquititlán: $3 \mathrm{~km}$ al este de El Rodeo, $J$ L. López G. 514 (MEXU); paraje a $600 \mathrm{~m}$ al este de Arroyo Hondo, $J$ L. López G. 516 (MEXU); Carpinteros, L. Vela G. 933 (MEXU); Paraje El Rodeo, 」 L. López G. 121 (MEXU); desviación a Carpinteros, 2 km al E de la carr. Zacualtipán-Metzquititlán, I. Méndez L. 32 (MEXU). Zacualtipán de Ángeles: $3 \mathrm{~km}$ al $\mathrm{N}$ de la desviación a Tlahuelompa, A. Monroy C. \& $S$ Valencia A. 97 (FCME); barranca de Tuzanapa, L. González Q. 812 (MEXU); Paraje La Virgencita, $2.5 \mathrm{~km}$ al E de Los Arcos, Zoquizoquiapan, E Guizar 5342 (MEXU); 7 km al oeste de Zacualtipán, R. Hernández M. 5389 (MEXU); 1 km al SE de Cuyamaloyan, F. G. Medrano 10673 (MEXU). Sin municipio: $4 \mathrm{~km}$ al NW de Apulco, carretera hacia Huayacocotla, S. Valencia A. \& G. Fores $F$. 2143 (FCME); 2 km al W de la presa, carr. Atotonilco-Pachuca, S. Valencia A. \& G. Fores F. 2181 
Appendix 1. Continuation.

(FCME); comunidad de las Trancas, $2 \mathrm{~km}$ al Sur de Venta Reyes, carr. Atotonilco-Pachuca, $S$ Valencia A. \& G. Fores F. 2180 (FCME).

Quercus oleoides Schlecht. et Cham. Calnali: En el poblado de Calnali, J I. Calzada 2498 (MEXU); $16 \mathrm{~km}$ de la desviación a Calnali, A. Monroy C. \& S. Valencia A. 118, 119, 120, 124 (FCME). Huautla: En el poblado de Coamitla, J I. Calzada et al. 2523 (MEXU, XAL). Huejutla de Reyes: Después de Huejutla de Reyes, $\rfloor$ M. Quintanilla s.n. -11-jun-1979- (FCME); 27 km SW Huejutla de Reyes-Tlanchinol; M. Torres \& Col. 52 (MEXU). Huehuetla: 8 km al NE de San Clemente, camino a Huehuetla, cerca de Santa Ursula, G. Fores F. 6525 (FCME); 2 km al SW del entronque de San Antonio El Grande, San Guillermo, G. Fores F. 6526 (FCME). Jacala: 7 km al S de Jacala, G. Castilleja s.n. 13-jun-1979 (FCME). Lolotla: 17 km al E de Ixtlahuaco, camino a Calnali, S VaIencia A. y G. Fores F. 2159, 2160 (FCME). Molango de Escamilla: Otongo, cerca del área minera, I. García G. et al. 58. San Felipe Orizatlán: Desviación a Huitzitzililngo $6 \mathrm{~km}$ al N de Orizatlán, $P$. Tenorio L. \& C. Romero de T. 2502 (MEXU); Hueytlali, R. Hernández H. 17 (FCME); El Naranjal, $R$. Hernández H. 21, 26 (FCME); Tepetzintla, R. Hernández H. 1 (FCME); Valle Verde, R. Hernández H. 3, 4 (FCME); 3 km al SSW de San Felipe Orizatlán sobre la desviación a Coacuilco, Y. García M. \& S. Valencia A. 320 (FCME); carr. Tamazunchale-San Luis Potosí- San Felipe Orizatlán, E Tovar 30, 31 (FCME). Tlanchinol: 17 km al sur de la desviación a Coacuilco, Y. García M. 321 (FCME); Rancho Tolapa carr. a Huejutla, S Valencia A. et al. 3751 (FCME); km 9 de la carr. a Lontla, 6 km al sur de Huayapa, A. Monroy C. \& S. Valencia A. 125 (FCME). Yahualica: Mesa Larga, MartínezPeña 1, 6 (FCME).

Quercus opaca Trel. Cardonal: El Cubo, $3 \mathrm{~km}$ al SE de barranca de Tolantongo, R. Cruz D. 6001 (FCME); El Cubo, $25.5 \mathrm{~km}$ al NE de Ixmiquilpan, barranca Tolantongo, R. Curz D. 5759 (FCME).

Quercus paxtalensis C. H. Mull. Chapuluacán: $800 \mathrm{~m}$ al E, O. Alcantara A. \& R. Mayorga S 3110 (FCME); aproximadamente $950 \mathrm{~m}$ al E, O. Alcanthara A. y R. Mayorga S. 3159 (FCME); aproximadamente $980 \mathrm{~m}$ al NE, O. Alcantara A. \& R. Mayorga S 3826 (FCME). Lolotla: a $1.74 \mathrm{~km}$ al S de Tenango, A. Ponce V. 250 (FCME); desviación a Lontla, Temazate, E Pérez M. 10 (FCME). San Bartolo Tutotepec: aproximadamente $2.5 \mathrm{~km}$ al N de El Fresno, S. Valencia A. \& G. Fores F. 5294 (FCME); aproximadamente $3.5 \mathrm{~km}$ al NE de El Fresno, S. Valencia A. \& G. Fores F. 5298 (FCME). Tlanchinol: $\mathrm{km} 165$ de la carretera Tlanchinol-Tampico, aprox. $5 \mathrm{~km}$ al $\mathrm{S}$ de la desv. a Lontla, $S$ Valencia A. et al. 3746 (FCME); $5 \mathrm{~km}$ al E de Tlanchinol, I. Luna V. 9 (FCME); O. Alcantara A. \& R. Mayorga S. 3154 (FCME); camino a Tierra Colorada, I. Luna \& S. Ocegueda 327 (FCME).

Quercus pinnativenulosa C. H. Mull. Chapulhuacán: 1 mi NE of Puerto del Zopilote, 3 3/4 mi SW of Chapulhuacán, A. May N. 551 (MEXU); Puerto Oscuro, L. González Q. 1651 (ENCB); Las Peñitas, H. Hernández G. 89 (FCME); 1 km al S de Amilal, sobre la carr. 85, M. Mora ل, 135 (FCME); Chapulhuacán, 2 km al NE, O. Alcántara A. \& R. Mayorga S. 3628 (FCME); Chapulhuacán, $300 \mathrm{~m}$ al N, R. Mayorga S. y O. Alcántara A. 844 (FCME). Tlanchinol: aprox. 2 km al S de San Cristóbal, S. Valencia A. et al. 3742 (FCME); aprox. $0.5 \mathrm{~km}$ al N de San Cristobal, hacia la carr. A. Ixtlahuaco, S. Valencia A. et al. 3743 (FCME).

Quercus polymorpha Schltdl. et Cham. Chapuluacán: Cerro de la Golondrina, C. Hernández M. 98 (FCME); El Sabinito, S. Cartujano 600 (FCME). Eloxochitlán: Gilo, 4 km de Eloxochitlán, $A$. Monroy C. \& S. Valencia A. 132, 133, 139 (FCME); Gilotla, R. Hernández M. et al 6772 (MEXU). Jacala: $11 \mathrm{~km}$ al S de Jacala, M. Mora J 119, 120 (FCME); $9 \mathrm{~km}$ al S de Jacala, O. Alcanthara A. \& R. Mayorga S. 3605 (FCME); $3 \mathrm{~km}$ al W de Hilojuanico, $8 \mathrm{~km}$ al W de Jacala, carr. de terracería a Pacula, G. Fores F. 6416, 6417 (FCME); Thickets between Hilo Juanico and Barranca Seca on trail from Jacala to Pacula, H. E Moore J. \& C. E Wood J. 3844 (MEXU). Lolotla: a 2.43 km al E de Lolotla, A. Ponce V. 189 (FCME). Metztitlán: Parte alta de las barrancas de Ixcatlán, ladera exposición W en la proximidad al paraje Mesa Grande $2.5 \mathrm{~km}$ de la población del mismo nombre, E Guízar N. et al. 5211 (MEXU). Molango de Escamilla: Desviación a Acuimantla, carr. Otongo-Tepehuacán de Guerrero, S Ramírez B. 14 (FCME). Nicolás Flores: La Cruz, 2 km al norte de Nicolás Flores, $A$. Monroy C. \& S. Valencia A. 55 (FCME); en lugar llamado La Mora, Villahermosa, S. N. Rufino s.n. (MEXU). Pacula: 11 km al N de Milpas Viejas, 38 km al W de La Estancia, G. Fores F. 6415 (FCME). Pisaflores: $1 \mathrm{~km}$ al E de Pisaflores, S. L. Cartujano P. 109, 110 (FCME). San Bartolo Tutotepec: El Fresno, S Valencia A. \& G. Fores F. 5300 (FCME); 2 km al NE de la entrada de San Bartolo Tutotepec, camino a Huehuetla, G. Fores F. 6521, 6522 (FCME). Tenango de Doria: al NE de Agua Zarca, S. Cartujano et al., 190 (FCME); 2 km al SO de Agua Zarca, S. Cartujano 537 (FCME); 3.5 km al SO de Agua Zarca, S. Cartujano et al. 6, 14, 17 (FCME); $1.5 \mathrm{~km}$ al NE de Agua Zarca, S. Cartujano 282 (FCME); 9 kmal SW de la entrada a San Bartolo Tutotepec, camino a Tenango de Doria, G. Fores 
Appendix 1. Continuation.

F. 6527 (FCME). Tlanchinol: El Chalahuite, $1.8 \mathrm{~km}$ al O, desviación al Coyol, O. Alcantara A. \& $R$. Mayorga S. 1071, 3318, 3870; R. Mayorga S. \& O. Alcantara A. 1071 (FCME). Zimapán: 17 km al noreste de Zimapán, R. Hernández M. 3710 (MEXU); 19 km al norte de Zimapán, hacia la mina, $R$. Hernández M. 6772 (MEXU, XAL); Cañón del Río Tolimán, S. Zamudio y E Pérez C. 9120 (MEXU). Sin municipio: $5 \mathrm{~km}$ al S de El Lobo, S. Cartujano et al. 325; Parque Nacional Los Mármoles, Maguey Verde, E Álvarez Z. 74 (MEXU).

Quercus pringlei Seemen. Cardonal: Barranca de Tolantongo, F. González M. et al. 10530, 10532, 10539 (MEXU); R. Hernández M. 3781 (MEXU); cerro Boludo de Tolantongo, 42 km al N de Ixmiquilpan, F. González M. et al. 9611, 9627 (MEXU); Cañada de La Piedra Cerrada, barranca de Tolantongo, F. González M. 9469 (MEXU); Tercera ampliación del ejido Julián Villagrán, E Gil A. 38 (MEXU); 2 km delante de San Cristobal, A. Monroy C. \& S. Valencia A. 32, 33 (FCME).

Quercus repanda Bonpl. Acaxochitlán: $1 \mathrm{~km}$ al SW del límite con Tlaxcala, 2 km al NE de Zacacuautla, hacia Honey, G. Fores F. 6482 (FCME); aprox. 3 km al N de la Mesa, $J$ L. Contreras 9056, 9057 (FCME), 1 km al W del entronque de la carr. Tepepa-Acaxochitlán, G. Fores F. 6474 (FCME). Cuautepec de Hinojosa: 9 km al SE de Santa María Nativitas, G. Fores F. 6456, 6458 (FCME); 2 km al noroeste de El Aserradero, 4 km al SW de San Lorenzo Sayula, G. Fores F. 6430 (FCME); 1 km al SE del poblado El Aserradero, carr. Hacia La Cañada, G. Fores F. 6418 (FCME). Epazoyucan: Cerro de las Navajas, S. Valencia A. 1148, 1149, 1150 (FCME); Cerro de las Navajas, arriba de la mina de pomex, S Valencia A. et al. 3730, 3732 (FCME). Mineral del Chico: El Chico, S Valencia A. 2109 (FCME). Singuilucan: Volcán del Agua, G. Martínez P. s.n. (FCME), Volcán del Agua, G. Martínez P., s.n. 23-jun-2001 (FCME). Tulancingo de Bravo: Tulancingo, B. González H. 2264 (FCME). Aprox. $3 \mathrm{~km}$ al N de La Mesa, $J$ L. Contreras 9056, 9057 (FCME); $5 \mathrm{~km}$ al N de Tulancingo, S. Valencia A. et al. 3727 (FCME).

Quercus rugosa Née Acaxochitlán: 3 km al NE de Ojo de Agua de las Palomas o 3 km al SW de Tepepa, G. Fores F. 6468, 6469 (FCME). Agua Blanca de Iturbide: 4 km al NW de Apulco, carr. hacia Huayacocotla, S. Valencia A. 2146 (FCME); 6 km al NE de Agua Blanca, en Los Cubes, carr. hacia Huayacocotla, S. Valencia A. 2150 (FCME). Chapantongo: 4 km al SO de El Astillero, G. Fores F. 6294, 6295 (FCME). Cuautepec de Hinojosa: 2 km al SE de San Lorenzo Sayula, carr. A Tezoncualpa, G. Fores F. 6445, 6446, 6448 (FCME); 1 km al SE de Tezonocualpa, área protegida El Campanario, G. Fores F. 6453 (FCME); 3 km al NE de El Encinal, 17 km al NE de Sta Ma. Nativitas, G. Fores F. 6464 (FCME). El Arenal: Los Frailes, 6 km al noreste de Tepenené, R. Hernández M 4955 (MEXU). Huichapan: $4 \mathrm{~km}$ al E del Astillero, camino de Terracería a Huichapan, G. Fores F. 6298 (FCME). Mineral del Chico: 10 km al NO de Pachuca, Sainz R. s.n. (FCME); 8 km al SE de El Chico, \Monroy J s.n. (FCME); El Chico, S. Valencia A. 2006, 2061 (FCME); km 8 de la carr. Pachuca-El Chico, J Jménez R. s.n. nov. 1975 (FCME); Presa Jaramillo, E Pérez M. 6 (FCME); El Chico, ladera oeste de la presa Jaramillo, A. Monroy C. \& S Valencia A. 1, 2, 3, 4 (FCME). Mineral del Monte: carretera Mineral del Monte hacia Mineral del Chico, M. Mora $\downarrow$ 2002, 2005 (FCME). Nopala de Villagrán: 7 km del entronque de la carr. Jilotepec-Huichapan, hacia San Lorenzo Nenamicoya, G. Fores F. 6286, 6288 (FCME). Omitlán de Juárez: Omitlán, a 3 km de la desviación de la carretera, A. Monroy C. \& S. Valencia A. 14 (FCME); Santa Elena, al N de Omitlán, A. Monroy C. y S. Valencia A. 137 (FCME). Sin municipio: El Durazno, $J$ L. Contreras 9068, 9070 (FCME); Afueras de La Mesa, $\downarrow$ L. Contreras 9053, 9054 (FCME).

Quercus rysophylla Weath. Chapulhuacán: Aproximadamente $980 \mathrm{~m}$ al NE de Chapulhuacán, $O$. Alcantara y R. Mayorga 3491 (FCME); al NE de Agua Zarca, S. Cartujano et al., 176 (FCME); Santa Ana de Allende, 3 km al este del camino a San Rafael, O. Alcántara A. 989 (FCME). Jacala de Ledezma: 11 km al S de Jacala, M. Mora J 124 (FCME); camino que conduce a Laguna Seca, viniendo por Jacala, entrando por El Pinalito, A. Frias-Castro et al. 538 (FCME). Molango de Escamilla: Otongo, I. García G. 11 (MEXU). Pisaflores: La Peña, 0.5 km al oeste, O. Alcántara A. \& R. Mayorga S 3242 (FCME); pasando la Peña, camino de Pisaflores a Agua Zarca, S. Valencia A. et al. 3752 (FCME).

Quercus sapotiifolia Liebm. San Bartolo Tutotepec: $3 \mathrm{~km}$ above San Bartolo Tutotepec along road to San Miguel, L. Kelly 1246, 1247 \& K. C. Nixon (MEXU). Yahualica: Mesa Larga, Martínez-Peña 3, 5 (FCME).

Quercus sartorii Liebm. Calnali: $16 \mathrm{~km}$ de la desviación a Calnali, A. Monroy C. \& S. Valencia A. 123 (FCME). Chapulhuacán: aprox. $950 \mathrm{~m}$ al E de Chapulhuacán, O. Alcántara A. \& R. Mayorga S. 3159 (FCME); Cerro Los Jarros, $3 \mathrm{~km}$ al N de Chapulhuacán, O. Alcanthara A. \& R. Mayorga S. 3670 (FCME). Eloxochitlán: Camino a Eloxochitlán, $6 \mathrm{~km}$ de la desviación, A. Monroy C. \& S Valencia A. 156, 157 (FCME); 2 km de Juarez, A. Monroy C. \& S. Valencia A. 135 (FCME). Jacala 
Appendix 1. Continuation.

de Ledezma: $11 \mathrm{~km}$ al S de Jacala, M. Mora J 112, 115 (FCME); $9 \mathrm{~km}$ al S de Jacala, A. Monroy C. \& S Valencia A. 85, 87, 89 (FCME). Lolotla: a $2.51 \mathrm{~km}$ al E de Lolotla, A. Ponce V. 301,302 (FCME); a $2.33 \mathrm{~km}$ al E de Lolotla, A. Ponce V. 184 (FCME); Monte Grande, 」 A. Escutia 3, 4, 7, 8, 14, 20 (FCME); 30 km al SW de Tlanchinol, Y. García M. 324 (FCME); 9 km al E de Ixtlahuaco camino a Calnali, S. Valencia A \& G. Fores F. 2158 (FCME). La Misión: Álamo, Rancho Viejo, E Tovar 37 (FCME). Lolotla: Monte Grande, 」 A. Escutia 3, 4, 7, 8, 14, 20 (FCME); $6 \mathrm{~km}$ al E de Ixtlahuaco, camino a Calnali, S. Valencia A. \& G. Fores F. 2156 (FCME); 9 km al E de Ixtlahuaco, camino a Calnali, S. Valencia A. \& G. Fores F. 2158 (FCME); a $2.3 \mathrm{~km}$ al E de Lolotla, A. Ponce V. 184 (FCME); a $2.5 \mathrm{~km}$ al E de Lolotla, A. Ponce V. 301, 302 (FCME); $30 \mathrm{~km}$ al SW de Tlanchinol, Y. García M. 323 (FCME). Molango de Escamilla: Molocotlán, 2.3 km al NE, R. Mayorga S. 464 (FCME); Molocotlán, $1.3 \mathrm{~km}$ al NE, R. Mayorga S 391 (FCME); Laguna de Atezca, E Martínez A. 102, 103, 104 (FCME). Pachuca de Soto: (Pacula) 33 km al Noreste de Zimapán, R. Hernández M. 3729 (XAL). Pacula: Pacula, A. Sánchez S. 4008 (FCME); 6 km al N de Milpas Viejas, 33 km de La Estancia, carr. Pacula, G. Fores F. 6412, 6413 (FCME). Tenango de Doria: El Damo, 2 km al SE de Tenango de Doria, I. Luna et al. 872, 913 (FCME); Agua Fría, aproximadamente $2.5 \mathrm{~km}$ al E de El Damo, O. Alcantara A. 1512 (FCME); AI NE de Agua Zarca, S Cartujano P. et al. 189 (FCME); 3.5 $\mathrm{km}$ al SO de Agua Zarca, S. Cartujano P. et al. 18 (FCME). Tlanchinol: camino a Tierra Colorada, Isolda Luna y Susana Ocegueda 327, 444, 475, 544 (FCME); camino Tlanchinol-Coatlán, I. Luna et al. 678, 694 (FCME). Zacualtipán de Ángeles: 2 km al N de Jalapa, A. Monroy C. \& S. Valencia A. 112, 113 (FCME). Zimapán: 1 km al S de Minas Viejas, S. Valencia A. 1995, 1996 (FCME).

Quercus sebifera Trel. Chapulhuacán: $3 \mathrm{~km}$ al S de Amolal, M. Mora J126 (FCME); $1 \mathrm{~km}$ al S de Amolal, sobre la carr. 85, M. Mora $\rfloor 132$ (FCME). Jacala de Ledezma: $11 \mathrm{~km}$ al S de Jacala, $M$. Mora J 116b, 117, 121, 122b, 123 (FCME); Minas viejas, A. Monroy C. \& S. Valencia A. 82, 83 (FCME); entrada al Parque Nacional Los Mármoles, carretera Francisco I. Madero-Jacala, G. Fores F. 5826 \& M. Mora J (FCME, HUMO). Nicolás Flores: Parque Nacional Los Mármoles, A. Sánchez G. 4024 (MEXU). Tecozautla: Maguey Verde, Parque Nacional Los Mármoles, carretera Francisco I. Madero-Jacala, G. Fores F. 5829, 5830 y M. Mora J (FCME, HUMO). Zimapán: La Majada, 2025 km al noreste de Zimapán, R. Hernández M. 6532 (XAL, MEXU); Minas Viejas, near km 255 on highway betwen Zimapán and Jacala, H. E Moore, f. \& C. E Wood, f. 3881 (MEXU); $2 \mathrm{~km}$ al N de Maguey Verde, $S$ Valencia A. 1986b (FCME); 5 km al NW de Garabatos, camino a Cajay o Planta Concentradora, G. Hores F. 6372 (FCME).

Quercus tinkhamii C. H. Mull. Cardonal: camino a las grutas de Tolantongo, a $1 \mathrm{~km}$ del módulo de información, A. Monroy C. \& S Valencia A. 34, 35 (FCME). Jacala: Entrada al Parque Nacional Los Mármoles, carretera Francisco I. Madero-Jacala, G. Fores F 5825 \& M. Mora J (HUMO). Zimapán: 17 km al Noreste de Zimapán, R. Hernández M. 3709 (MEXU); 5 km al N de Maguey Verde, S. Valencia A. 1978 (FCME); 5 km al NW de Garabatos, camino a Cajay o Planta concentradora, G. Fores F 6369 (FCME).

Quercus trinitatis Trel. Molango de Escamilla: $7 \mathrm{~km}$ al E de Molango, en la brecha a Jalamelco, S. Valencia A. \& G. Fores F. 2153 (FCME). Tenango de Doria: El Cirio, aprox. $1.2 \mathrm{~km}$ al O de San Nicolás, O. Alcantara A. \& E Ortiz B. 1247 (FCME); El Potrero, O. Alcantara et al. 1323 (FCME); El Potrero, aprox. $4 \mathrm{~km}$ al SO de Tenango de Doria, I. Luna V. et al. 1322, 1360, 1493 (FCME); km 36 carr. Metepec- Tenango de Doria, $\downarrow$ L. Contreras 315 (FCME); $11 \mathrm{~km}$ al Oeste de tanango de Doria, R. Hernández M. 3422 (XAL); km 23 de la carr. Tenango de Doria-Agua Zarca, S. Valencia A. 5284 (FCME); 4 km al SW de Tenango de Doria, camino a Metepec, G. Fores F. 6530 (FCME); $9 \mathrm{~km}$ al SW de Tenango de Doria, $1 \mathrm{~km}$ al NE de El Potrero, G. Fores F. 6534 (FCME); $14 \mathrm{~km}$ al SW de Tenango de Doria, 4 km al SW de El Potrero, camino a Metepec, G. Fores F. 6535 (FCME). Tlanchinol: Ejido La Mojonera, aprox. $5 \mathrm{~km}$ al SE de Zacualtipán, R. Mayorga S. \& O. Alcanthara A. 982 (FCME); desviación a Lontla, El Temazate, E Pérez M. 11 (FCME). Xochicoatlán: 9 km sobre el camino de terracería a Jalamelco, Y. García M. 329, 330 (FCME). Zacualtipán de Ángeles: Río Teponapa, H. E Moore, ․ $5348(\mathrm{BH})$; Paraje La Laja, $1 \mathrm{~km}$ del poblado de Tlahuelompa, Ma. T. Amaya V. Z7 (XAL); 1 km hacia la desviación a Tlahuelompa, carretera Zacualtipán-Pachuca, S. Valencia A. \& G. Fores F. 2166, 2167, 2168, 2172 (FCME); 3 km hacia la desviación a Tlahuelompa, carr. Zacualtipán-Pachuca, S. Valencia A. \& G. Fores F. 2169 (FCME); 1 km de Tizapala sobre la carr. A Tlahuelompa, Y. García M. 333, 334, 335 (FCME); 8 km al N del centro de Tlahueloimpa, $A$. Monroy C. \& S Valencia A. 93, 94 (FCME); desviación a Tlahuelompa, a partir de la carr. PachucaZacualtipán, S. Valencia A. 3317 (FCME). Sin municipio: barranca below Trinidad, C. G. Pringle 277 (8888) (ENCB, MEXU); 60 km al O de Barretal, F. González M. 6388 (ENCB). 
Appendix 1. Continuation.

Quercus xylina Scheidw. Acaxochitlán: $1 \mathrm{~km}$ de San mateo, carr. a Honey, $2 \mathrm{~km}$ al $\mathrm{N}$ del Crucero Acaxochitlán-Tulancingo, G. Fores F. 6479 (FCME). Chapantongo: ca. $8 \mathrm{~km}$ al SO del entronque de la carr. Amealco-Sayula, hacia Rancho Nuevo, G. Fores F. 6316 (FCME); 5 km del entronque de la carr. Amealco-Sayula, hacia Juchitán-El Capulín, G. Fores F. 6328 (FCME); El Colorado, 2 km al SE del Capulín (8 km del entronque de carr. Amealco-Sayula), G. Fores F. 6331, 6333 (FCME). Cuautepec de Hinojosa: $2 \mathrm{~km}$ al SW de San Lorenzo Sayula, $4 \mathrm{~km}$ al NE de El Aserradero, G. Fores F. 6436 (FCME); $3 \mathrm{~km}$ al NE de El Encinal, $17 \mathrm{~km}$ al NE de Sta María Nativitas, G. Fores $F$. 6463 (FCME). Huichapan: $3 \mathrm{~km}$ al E de Jonacapa, carr. Huichapan-Ixmiquilpan, G. Fores F. 6363 (FCME); 13 km al S de Jonacapa, G. Fores F. 6383 (FCME). Nopala de Villagrán: aproximadamente $9 \mathrm{~km}$ al SE de Las Maravillas, G. Fores F. 6305 (FCME); 2 km al NO de San Sebastián de Juárez (12 km al SE de Maravillas), G. Fores F. 6339 (FCME); $2 \mathrm{~km}$ al norte de La Palma o $10 \mathrm{~km}$ al N de San Lorenzo Nenamicoya, G. Fores F. 6341, 6344 (FCME). Omitlán de Juárez: Santa Elena, al N de Omitlán, A. Monroy C. \& S. Valencia A. 136, 148, 154 (FCME). Pacula: Pacula, A. Sánchez G. 4026 (FCME). San Agustín Tlaxiaca: La Virgen, aprox. $6 \mathrm{~km}$ después de la desviación de la carr. Benito Juárez-Chapultepec de Pozos, Sierra del Monte Alto Temoaya, Ejido Puerto México, I. Díaz V. 824 (FCME). Singuilucan: $4 \mathrm{~km}$ al SW de Los Romero, Pachuca a $8 \mathrm{~km}$ del entronque de la carr. Tulancingo, G. Fores F. 6489, 6495 (FCME). Zacualtipán de Ángeles: $3 \mathrm{~km}$ al N de la desviación a Tlahuelompa, A. Monroy C. \& S Valencia A. 96, 98, 102, 104, 105 (FCME); 2 km al S de Tlahuelompa, en el camino a Tizapán, A. Monroy C. \& S. Valencia A. 109 (FCME); 2 km al norte de Jalapa, A. Monroy C. \& S. Valencia A. 110, 111 (FCME). 